$$
\begin{gathered}
\text { UNIVERSITY OF CALIFORNIA } \\
\text { COLLEGE OF AGRICULTURE } \\
\text { AGRICULTURAL EXPERIMENT STATION } \\
\text { BERKELEY, CALIFORNIA }
\end{gathered}
$$

\title{
History of Cooperation in the Marketing of California Fresh Deciduous Fruits
}

\author{
ERICH KRAEMER and H. E. ERDMAN
}

\section{BULLETIN 557}

SEPTEMBER, 1933

CONTRIBUTION FROM THE

GIANNINI FOUNDATION OF AGRICULTURAL ECONOMICS 


\section{CONTENTS}

Early horticultural history of the deciduous fruit industry

Beginnings of collective action . . . . . . . . . . 5

The California Fruit Growers' and Dealers' Association . . . 5

Local group action by growers . . . . . . . . . . . . . . . 7

Early influence of general-purpose farm organizations . . . . . . . . . 99

Agricultural societies . . . . . . . . . . . . . . . . 9

Farmers' clubs . . . . . . . . . . . . . . . . . . 9

Granges (Patrons of Husbandry) : . . . . . . . . . . 10

The California Fruit Union . . . . . . . . . . . 13

The California Fruit Growers' and Shippers' Association . . . . . . 29

Continued efforts to establish a central cooperative agency . . . . . . 36

The California Fruit Exchange . . . . . . . . . . . . . . . 41

Local and regional cooperative developments . . . . . . . . . . 69

Florin Fruit Growers' Association . . . . . . . . . . . . 70

Newcastle Fruit Growers' Association . . . . . . . . . . . . 71

Cooperative movement in the Watsonville region

Corralitos Fruit Growers Incorporated . . . . . . . . 75

Loma Fruit Company

Sebastopol Apple Growers' Union ‥. . . . . . . . . . 79

The Gravenstein Apple Growers' Association . . . . . . . . . . 84

The California Gravenstein Apple Growers . . . . . . . . 85

Growers' Cooperative Agency . . . . . . . . . . . . . . . 87

Recent plans of combining growers' and dealers' interests . . . . . . . 90

Summary of early plans . . . . . . . . . . . 90

The California Fruit Exchange as a member of the California Fruit Distributors

State Bureau of Distribution

Beginnings of the post-war clearing-house movement . . . . . . . . 95

Clearing houses for grapes . . . . . . . . . . . . . . . . 97

Clearing houses for fresh deciduous-tree fruits : . . . . . . . 104

Grower-dealer organizations in the Watsonville region. .106

Watsonville Apple Distributors . . . . . . . . . . . . . 106

The second joint marketing organization

Watsonville Apple Growers' and Packers' Association : . . . . . 109

Watsonville Apple Selling Organization . . . . . . . . . . . 110

Pajaro Valley Fruit Association . . . . . . . . . . . . . . 110

Grower-dealer organizations in the Sebastopol region . . . . . 111

Gravenstein Growers and Packers . . . . . . . . . . . . 111

California Gravenstein Apple Growers . . . . . . . . . . . . . . 112

Summary and conclusions . . . . . . . . . . . . . . . . . 117

Acknowledgments . . . . . . . . . . . . . . . . . . . . . 121 


\title{
History of Cooperation in the Marketing of California Fresh Deciduous Fruits ${ }^{1,2}$
}

\author{
ERICH KRAEMER ${ }^{3}$ AND H. E. ERDMAN ${ }^{4}$
}

\section{EARLY HORTICULTURAL HISTORY OF THE DECIDUOUS FRUIT INDUSTRY}

While the history of the California deciduous-fruit industry dates back to the beginning of the settlement of Alta California by the Franciscan fathers in 1769 , the first real signs of commercial fruit production did not appear until the days of the Gold Rush in 1849. Commercial production of deciduous fruits in California is, therefore, of comparatively recent origin. But within its eighty years of existence, and particularly since the early seventies, it has had a remarkable development.

The tree fruit which was produced about the early Missions of the Franciscan monks was chiefly grown from seeds brought to California by vessels bearing supplies for the Missions. As gardens and orchards were soon planted at practically all of the Missions, it was not long before a number of varieties of fruit were to be found there.

According to Lelong, ${ }^{5}$ as early as 1792 "there were growing, near the Mission San Jose, apples, pears, apricots, peaches, and figs; and at San Buenaventura, in addition to these, oranges, limes, grapes, olives, and pomegranates." Although there were not more than about five thousand bearing trees in the various Missions at that time, these plantings contributed much to the growth of horticulture in the state. "They showed the possibilities in fruit culture, and furnished seeds, stock, cions, and from the vineyards, grape cuttings, for many orchards and vineyards." He also states that farther north at Fort Ross, in Sonoma County, some Russians in 1812 planted an orchard of mixed fruits, including apples, apricots, pears, cherries, and vines. Gradually at various points settlers planted small orchards, always for home use.

1 Received for publication November 29, 1932.

2 Paper No. 40, The Giannini Foundation of Agricultural Economics.

3 Research Assistant on the Giannini Foundation, resigned November 1, 1931.

${ }_{4}$ Professor of Agricultural Economies, Agricultural Economist in the Experiment Station, Agricultural Economist on the Giannini Foundation.

5 Lelong, B. M. Horticultural history. California State Board of Horticulture, Annual Report 1892:33-34. 
There was little or no commercial interest in the fruit growing of those early days. However, with the increase of population during the Gold Rush and the high prices paid for fruit at that time by the miners and others, the situation changed. These high prices stimulated the production of fruit for sale, particularly around the mining camps. Some of the men who were not caught by the "gold fever" and who devoted their efforts to fruit growing soon discovered that when fruit was selling at $\$ 0.50$ to $\$ 1.00$ a pound their orchards were veritable "gold mines."

For a time high prices stimulated "imports" of large quantities of dried fruits to California. By 1866 it was pointed out that "with the help of Oregon, ... we shall be able to supply the demand for all the principal fruits on this coast the coming year." 6 Three years later after the completion of the overland railroad it was pointed out that about 300 tons of pears, apples, grapes, and plums had been sent East by railroad and that the eastern market might prove very advantageous "if we can lay [our fruit] down in the eastern cities in good order and at cheap freights." Still later, after reporting that "70 full cars" of fruit had been shipped East in 1870 and 115 cars in 1871 (mostly pears), Reed ${ }^{8}$ ventured the forecast that in the future as many as 1,000 cars a year might be shipped.

The completion of the overland railroad further stimulated plantings for commercial fruit production. The beginning of the seventies, therefore, marks the real beginning of commercial production of deciduous fruits in the state.

Shipments of fresh deciduous fruits out of California by rail increased rapidly. In 1871 rail shipments out of the state were 916 tons. In 1880 , 1,571 tons were shipped and by 1890 shipments had reached 34,042 tons. ${ }^{9}$ By 1930 shipments had mounted to more than $1,500,000$ tons. ${ }^{10}$

Although the California deciduous-fruit industry is now widely scattered over the state, with its total length of about 800 miles and an average width of about 200 miles, there is a considerable degree of regional specialization in production. In the course of something like

6 California State Agr. Soc. Trans. 1866-67:35.

7 California State Agr. Soc. Trans. 1868-69:22.

8 Reed, C. W. Fruit culture. California State Agr. Soc. Trans. 1870-71:454. (The figure 115 may be in error.)

9 Lelong, B. M. Horticultural history. California State Board of Horticulture, Annual Report 1892:36.

10 Pacific Fruit Express Company's reports of "Total California Interstate Deciduous Tree Fruit and Grape Shipments." 
three-fourths of a century of experimentation under the varied climatic, soil, and topographic conditions of the state, numerous regions have proved themselves peculiarly adapted to the production of certain products. ${ }^{11}$

\section{BEGINNINGS OF COLLECTIVE ACTION}

Some initial efforts on the part of California deciduous-fruit growers to improve the marketing of their products by collective action occurred in the late sixties. These efforts were concerned with the shipment of fresh deciduous fruits both to California points and to eastern markets. They represented not only local group action but involved the establishment of an organization designed to benefit the deciduous-fruit industry of the state. This state-wide organization furnishes an early example of the combining of growers' and dealers' interests in a single enterprise.

The California Fruit Growers' and Dealers' Association.-Probably the earliest movement for collective action in connection with the sale of fresh deciduous fruit was a movement in 1869 to form an association of producers and dealers. It occurred during the year in which new markets had been opened to California products by the eagerly awaited completion of the overland railroad, and aimed to develop these additional outlets. The question of shipping fruit to the East at once received attention because it was generally realized that the new market area was not only promising, but also necessary in view of the rapidly increasing production of fruit in the state. ${ }^{12}$

It was also recognized by both growers and dealers that a successful development of the eastern markets for California fresh fruit was greatly dependent upon the support of the railroads, particularly since freight rates were extremely high and were considered a serious handicap to the development of the new business. It was likewise pointed out

11 For detailed information on the geographical distribution of the acreage of deciduous fruits in California see California Crop Reports, issued by the California Crop Reporting Service, and California Agr. Exp. Sta. Bulletins 423 (out of print), 429 (out of print), 445 (out of print), 452, 459, 488, 547, and Ext. Cir. 1 (out of print).

12 The selling of fruit in the East had been in the minds of Californians for some time. As early as 1858, an experimental shipment of grapes to New York by steamer was made. The fruit was packed with sawdust in wooden boxes. In view of the high ocean freight-25 cents a pound for express freight and $12 \frac{1}{2}$ cents for slow freight-and the long way around the Horn, this shipment was extremely speculative and probably ended in a loss. See: California Farmer 10(12):92. 1858 . 
that, if the best sales results were to be achieved, only good fruit should be shipped, and sound methods of packing and shipping used. ${ }^{13}$

In view of these common problems, the growers and dealers met in San Francisco on July 7, 1869. At that meeting, which was attended by about 40 persons, they decided to establish an organization for their mutual benefit. What they thought about the expediency of united action and what they desired to accomplish is stated briefly by the preamble of the organization's constitution :

Whereas, It is becoming more and more apparent from year to year that the production of fruit in this State is, and will continue to be, greatly in excess of the demand of our limited home market, and that a fair compensation to fruit growers requires that new markets should, if possible, be made available; therefore, we, the fruit growers and dealers of California, for the protection of our interests, and the further successful development of our branch of Agriculture, form ourselves into a permanent association, to be known as the California Fruit Growers' and Dealers' Association.14

The set-up of this association was very simple. It was provided that the board of directors should represent the main fruit-growing districts of the state. It was further declared (Article VII of the by-laws) that the association should be open to any fruit grower or dealer upon payment of a fee of five dollars and the signing of the constitution and by-laws.

In accordance with the desire of achieving concessions from the transportation companies, a committee was immediately appointed to confer with railway officials concerning the reduction of freight rates. This was done pursuant to the adoption of a resolution reading as follows:

Resolved, That an organized effort be made by the fruit growers here represented to obtain such a reduction of the rates of freight now charged by the transcoutinental railroad companies-through proper representation to said companies of the absolutely prohibitory rates now ruling - of the vast amount of freight immediately available to them in consequence of such a reduction of the rates as shall enable the fruit grower to place his fruit in the eastern markets at a reasonable profit to himself, and of the great future importance which this fruit trade with the East would assume if properly encouraged.15

Although the California Fruit Growers' and Dealers' Association was established for the purpose of fostering the selling of California fruit in

13 The editor of the California Farmer in August, 1869, commented: “ . . we are confident that Califormia has a fruit market now opened to her that NEVER CAN BE TAKEN AWAY FROM HER. A fruit market, also that we can never glut, provided that we are wise in our shipments, and never send second-rate fruit, or fruit poorly packed." California Farmer 32(6):44. 1869.

14 California Farmer $31(24): 188$. 1869. The preamble and by-laws of the Fruit Growers' and Dealer's' Association are given in this issue.

15 California Farmer 31(24):188. 1869. 
the new markets in various ways, only the question of obtaining lower freight rates from the railroad companies seems to have received attention during the shipping season of 1869. Prices paid for California fruit in the East were still very high, ${ }^{16}$ and, most likely for this reason, the individual interests of the members were so strong that no further joint economic action was sought.

Whether the association survived the year of 1869 or not is uncertain because of the lack of adequate records. However, the movement among fruit growers and fruit dealers went on in the following year. Several meetings took place, but these were probably of an informal sort. They were called to discuss such questions as methods of collecting choice fruit for the eastern markets, the kind of fruit boxes to be used, the best time to ship, the most favorable markets, and steps to bring about a reduction of freight rates. It seems that this movement finally brought about some reduction in freight rates. ${ }^{17}$ But apart from that, it probably did not accomplish much. ${ }^{18}$

Local Group Action by Growers.-A few years after the movement among growers and dealers to foster the marketing of California fruit in the East, one or two cases of local group action occurred in which fruit growers alone endeavored to bring about improvements in connection with the shipment of their produce to California markets. In Santa Clara County the farmers had become dissatisfied with railroad services. Meager information is available, but the following report of statements made at a meeting of the San Jose Farmers' Club and Protective

16 The editor of the California Farmer reported on an experimental shipment in 1869: "The Experiment of sending Fruit over the Pacific Railroad to distant points, as far as Chicago, has been tried, and good returns made, we learn, to those who sent their Fruit. The price realized at Chicago was for Grapes fifty cents per pound, and for pears $\$ 10$ per Box. Those who pack carefully and pack only choice fruit will make a good thing of it; but the hurry-up man and the careless packer will lose his fruit and his labor and pay his own freight, too. We learn that ten tons will be sent forward this week from Sacramento to Chicago, and way Stations, equal to about Three Hundred and twenty-five Boxes. Should it realize the same rates as the first lot, it would be equal to about four hundred per cent above our Markets. So much our Pacific Railroad has done for our Fruitgrowers even with all their complaints against high tariff." California Farmer 32 (3):20. 1869 .

17 The California Farmer reported that the Railroad Directors "now offer to take fruit on their regular trains at the reduced rate of $\$ 500$ per car, and will prepare cars to carry it safe-or they will send it on express trains at $\$ 950$ per car. This is only $\$ 50$ per tun of $2,000 \mathrm{lbs}$. ( $2 \frac{1}{2}$ cents per lb.) or $\$ 95$ per tun (expense $9 \frac{1}{2}$ cents per lb.). This we esteem liberal and we hope it will be justly regarded." California Farmer 33(24):188. 1870.

18 The same journal makes the following comment: "We esteem the cause of non-success to the meeting and Committee was the want of a union of interest and purpose, somebody wants the buttered side of the loaf, the rule and control of all the business, and all the profits, and our hard working growers won't submit to it." California Farmer 33(19):148. 1870. 
Association on April 27, 1872, indicates the nature and scope of the activities :

Arrangements have already been made and a steamer is now running from Alviso to San Francisco, making night trips, and carrying strawberries, vegetables, etc., fresh from the farms, and landing them near the markets, without the rough handling, bruising and delay which has been experienced over the S. P. R. R. route. This has been brought about by a number of principal farmers in Santa Clara County, combining and pledging their patronage to the steamer. Before this combination of the farmers in self-defense, the railroad managers would not listen to any complaints ... What then cost the farmers $\$ 1$ to freight to San Francisco is now sent via Alviso by steamboat for 60 cents, and the commission men get better prices, and are much pleased with the arrangement. Before this move the Railroad Company refused to put on a night train. Now they are not only willing to run a night train, but they have reduced the price of freight to one-half the cost on the Alviso route, about onethird the rate formerly exacted.19

At the Napa County Farmers' Club in July, 1872, it was reported that fruit growers and other farmers in Alameda County had combined and hired a steamer for the transportation of their products. They were able to ship their products at $\$ 0.621 / 2$ a chest by steamer, whereas before they had paid the railroads $\$ 1.50$ a chest for small fruits. ${ }^{20}$ There may have been other informal ventures of similar nature which were not reported in the press.

It is possible that combined efforts of an informal kind to improve the marketing of fruit by similar and other means occurred much earlier. It is, however, difficult to get any evidence of such attempts because of the scarcity of records. The instances cited did not represent any informal or formal marketing transactions, since joint selling, although it may have been in the minds of the members of the California Fruit Growers' and Dealers' Association, apparently did not materialize. But, they were the immediate forerunners of cooperative marketing activities of deciduous-fruit growers which subsequently developed within the ranks of general farm organizations.

19 Pacific Rural Press 3:289. 1872. The same plan was worked out the next year under similar circumstances. (Pacific Rural Press 6:84. 1873.)

20 This reference may be to the aforementioned scheme. No further reference to it has been found. Alviso is in Santa Clara County just across the Alameda County line. Mr. Nash of the Napa Club said he had spent some time with Mr. Lewellyn in Alameda County. He (Mr. Nash) "had found there that the farmers had combined and hired a steamboat" etc. Pacific Rural Press 4:84. 1872. 


\section{EARLY INFLUENCE OF GENERAL-PURPOSE FARM ORGANIZATIONS}

The development of business cooperation among deciduous-fruit growers in California was influenced by three types of general-purpose farm organizations which developed during the period from 1850 to 1880, namely, the agricultural societies, the farmers' clubs, and the grange (Patrons of Husbandry). At first their influence was indirect, but later it became more and more direct.

Agricultural Societies.-The State Agricultural Society, formed in April, 1854, ${ }^{21}$ and the county and district agricultural societies were primarily concerned with such affairs as county and state fairs. However, they fostered the spirit of organization in general, and the discussion of economic questions was often prominent at their meetings.

The California State Horticultural Society, organized in $1879,{ }^{22}$ and some county associations concerned themselves primarily with the holding of periodic meetings for the purpose of discussing problems involved in the production of fruit. The State Horticultural Society, however, took a particularly important part in the formation of the California Fruit Union in 1885 and 1886.

Farmers' Clubs.-The farmers' clubs of the early seventies exerted a much stronger influence on the development of cooperative marketing than did the agricultural societies. Their number increased very quickly in the early seventies, particularly after they had combined to form a state organization-the California Farmers' Union. ${ }^{23}$ These clubs were mainly discussional clubs, and while they later took up discussion of political and general economic questions of the time, they frequently did discuss problems of fruit marketing and in some instances this led to action.

At a meeting of the Sacramento Farmers' Club in July, 1872, it was proposed to overcome the existing dissatisfaction with the prevailing

21 The State Legislature on May 11, 1854, passed an act incorporating this society and appropriating a sum for its maintenance. California State Agricultural Society's Fourth Annual Fair. Official Report. p. v. 1857.

22 Its first officers were President, E. W. Hilgard, College of Agriculture, Berkeley; Vice-President, J. Lewelling, St. Helena; Secretary, E. J. Wickson, editor, Pacific Rural Press, and later Dean of the College of Agriculture; Treasurer, G. P. Rixford, San Francisco. See: Pacific Rural Press 18:81, 172, 297. 1879.

23 The local clubs met at Sacramento on September 23, 1872, and formed a state organization, the California Farmers' Union. This organization has no connection with the present organization of that name. Pacific Rural Press 4:196. 1872. 
marketing system by establishing an agency for the sale and shipment of fruit. ${ }^{24}$ Shortly afterwards, at a meeting of the Napa Farmers' Club, the proposal was made that the farmers obtain "a portion of the wharf" and "ship their fruit direct, doing away with the middleman." In January, 1873, it was proposed that the farmers establish an agency in the City (San Franciseo) to replace the commissionmen. Nothing seems to have come of these proposals.

The members of the Farmers' Club at San Jose, however, went so far as to establish their own stalls in that city for the selling of all kinds of produce. They entrusted an agent with the management of these stalls who charged from $2 \frac{1}{2}$ to 10 per cent commission according to the turnover effected. ${ }^{25}$

Not only did the fruit growers of certain farmers' clubs consider the question of cooperation in their own communities, but they also contemplated the possibility of collaboration between their organizations. At a meeting of the San Jose Farmers' Club and Protective Association in December, 1872, the following resolution was adopted: "Resolved, That this Club will cooperate with the other clubs in such manner as may be thought best calculated to reduce the unnecessary expense of marketing fruit." ${ }^{26}$

Granges (Patrons of Husbandry).-The grange began active organization work in California early in $1873 .{ }^{27}$ As granges were organized in the various communities interest lagged in the farmers' clubs, and most of them soon ceased to function. ${ }^{28}$ On September 17, 1873, the California Farmers' Union formally turned its work over to the granges. ${ }^{29}$ When the farmer's' clubs gave way to the granges the marketing programs of the former were temporarily dropped. However, marketing continued to be a matter of dominant interest, and discussions of fruit marketing were continued in some of the granges which replaced the farmer's' clubs.

24 Pacific Rural Press $3: 244 ; 4: 36,68$. 1872. Other proposals are found in: Pacific Rural Press 4:197. 1872; 5:84. 1873.

25 This action was taken in connection with the opposition of the farmers to the city license system which forbade their selling their produce in the city from wagons direct to the consumers without a license. Pacific Rural Press 4:308, 389 . 1872.

26 Pacific Rural Press 4:389. 1872.

27 The first grange to be established on the Pacific Coast was that at Napa City, California, organized March 20, 1873. Pacific Rural Press 8:52. 1874.

28 In fact, interest may have been lagging earlier. An editor commented in February that he understood "attendance has fallen off greatly." California Farmer 39(4):28. 1873 .

29 Pacific Rural Press 6:184. 1873. At a previous meeting the Union had recommended the formation of local granges but had urged that they affiliate with the state Union. (Pacific Rural Press 6:153. 1873.) 
The first major result was the establishment of the Grangers' Fruit Association. This organization was formed by delegates from various granges in the state at a convention held at San Francisco on June 18, $1874 .{ }^{30}$ After the problems of improving the marketing conditions by cooperative selling had been discussed in the association for some time, the following resolution was adopted at a meeting on November 11, 1874 :

Resolved, That it is the sense of this Meeting that the time has now arrived when it is proper and our duty as Patrons of Husbandry and Fruit Growers to attend to our business in the sale of our products in the markets of California and elsewhere, and that we, the Grangers' Fruit Association of California, will now address ourselves to the task of establishing proper agencies, depots, and other means to that end. 31

A committee was immediately appointed to draft a plan of organization. It recommended the incorporation of a marketing agency under the name of California Grangers' Fruit Association with its principal place of business in San Francisco. This organization was to be established with a capital stock of $\$ 250,000$, divided into 10,000 shares of $\$ 25$ each. It was to be authorized not only to sell, can, and preserve all kinds of fruits, but also to carry on a general commercial business. ${ }^{32}$

'The report of the committee was adopted, but the California Grangers' Fruit Association never started business. The endeavors to bring it into existence coincided with the measures taken by the California State Grange to establish a general business association. As it was intended to have this latter association handle all kinds of agricultural commodities, including fruits, the fruit-growers' group decided, at a meeting on February 16, 1875, not to develop a separate association but to become members and patrons of the Grangers' Business Association.

The Grangers' Business Association was incorporated with a capital stock of $\$ 1,000,000$ divided into 40,000 shares of $\$ 25$ each. As the articles of incorporation say, it was to act "as a factor and broker and not otherwise." It was further provided that only members of the grange were allowed to subscribe to the capital stock. This association opened its offices in San Francisco in March, 1875. The first Board of Directors consisted of representatives of grain growers, wool growers, fruit growers, dairymen, and other farmers; this Board not only appointed a general manager, but also a special fruit agent.

30 Pacific Rural Press 8:165. 1874.

31 Pacific Rural Press 8:324. 1874.

32 It is interesting to note the manifold objects of the association. The actual combination of so many purposes was very common in the farmers' business organizations existing in those days. It must be recalled, however, that even today articles of incorporation often confer broad powers in order to make sure the organization is not hampered in its operations. 
As far as fruit marketing is concerned, it seems that the organization did sell dried fruits. ${ }^{33}$ Whether the selling of fresh deciduous fruits was developed is doubtful. No records of such sales have been found.

Evidently the Grangers' Business Association did not bring the desired results in the field of marketing fresh deciduous fruits, for one year after it had begun business a group of grangers became interested in the organization of a special company for the shipment of fruit to eastern markets. This group met at the Golden Gate Grange in August, 1876, with other growers, and organized the California Fruit Shipping Company with a capital stock of $\$ 50,000$. Its membership was not confined to grangers, but was open to all fruit growers. Furthermore, it was decided that it should buy and sell all kinds of fruits, as well as act as a forwarding and commission agent.

The movement to organize the company was stimulated by the favorable outcome of a number of experiments which had been made with a new patent refrigerator car. All the organization did was to go on with such experiments. In this connection it spent approximately $\$ 4,000$ which had been received by subscription. In addition, it spent about $\$ 3,000$ in building a refrigerator car and paying the necessary royalty. ${ }^{34}$

Out of this company grew one with a broader objective-the shipping of meat and fruit. This new enterprise, called the California Fruit and Meat Shipping Company was interesting. ${ }^{35}$ It was to combine the fruit and livestock interests of California, Nevada, and Utah in the joint enterprise of shipping meat and fruit. Furthermore, the founders had in mind the building of slaughter-houses at principal railroad shipping points to dress meat and ship it in quarters to San Francisco and to the East. ${ }^{36}$ The company was apparently based on the idea that the new refrigerator car would make meat and fruit a logical combination.

The capital stock of the organization was fixed at $\$ 500,000$ divided into 50,000 shares. It was also decided that stockholders in the old California Fruit Shipping Company should be entitled to turn in their certificates for shares in the new company.

33 Arrangements for selling dried fruit in the East had already been made by the Dairy Produce Department established by the Executive Committee of the California State Grange. See: Carr, F. S. The Patrons of Husbandry on the Pacific Coast. p. 181. San Francisco. 1875.

34 Pacific Rural Press 13:180. 1877.

35 At the organization meeting held in San Francisco it was explained that this company was to be "founded upon and to take the place of the Fruit Shipping Company," and that the refrigerator car built by the old company was to be turned over to the new. Pacific Rural Press 13:180. 1877.

36 The company apparently started in the meat packing business in Reno, Nevada, in the fall of 1877. (Pacific Rural Press 14:274. 1877.) No satisfactory information has been obtained as to whether the company actually started business nor what became of it. 
With these enterprises the first series of cooperative marketing efforts in the fresh-deciduous-fruit industry came to an end. They had developed as protests against transportation costs and conditions, and in opposition to prevailing business practices of fruit dealers. However, little or nothing came of any of these organizations. It was about ten years before another movement aimed at cooperative marketing developed among deciduous-fruit growers.

\section{THE CALIFORNIA FRUIT UNION}

It was not until 1885, when the California Fruit Union was proposed, that another movement for cooperative sale of fresh deciduous fruit got definitely under way, although the marketing problem had continued to be the subject of frequent discussions at farmers' meetings. Fruit production had been increasing rapidly and promised to inerease even more rapidly. The state markets were already crowded and an eastern outlet was needed. Shipments of deciduous fruits out of the state increased from a yearly a verage of $2,250,000$ pounds during 1871 to 1873 inclusive, to $19,000,000$ pounds in $1883 .{ }^{37}$ Eastern markets had been profitable and seemed to many to offer enormous possibilities. But at prevailing high prices market limitations became apparent to many observers. At the Fruit Growers' Convention in November, 1882, a committee, after reviewing marketing conditions, concluded that "the era of high prices cannot last. They necessarily and immediately limit the demand for any article." 38 Yet plantings were increasing. At the same convention Wickson ${ }^{39}$ said: "The tree plantings done in the south Santa Clara Valley alone in the last three years, in the one single item of apricots ... [will produce] ... quantities that at present prices the markets of the world will not require and will not take."

At the Fruit Growers' Convention in September, 1884, Kimball,40 a member of the State Board of Horticulture, painted a gloomy picture of the outlook. California, with its innumerable pests and plant diseases, and its great distance from markets, must compete with other states and with the countries of the world. He said: "The question of supply and demand will soon be an interesting one to the fruit grower. Diligence

37 See tabulation of shipments out of state annually from 1871 to 1884, as supplied by A. N. Towne, Manager Southern Pacific Railroad Company, in address of Morris M. Estee before State Agricultural Society, September 17, 1885. Pacific Rural Press 30:257. 1885.

38 Second Fruit Grower's' Convention Proceedings 1882:49.

39 Wickson, E. J. Second Fruit Growers' Convention Report. p. 58. November, 1882.

40 Kimball, Edwin. Fourth Fruit Growers' Convention Report. p. 4-7. September, 1884. 
and labor may keep the orchards healthy and productive, but then to the problem of saving the vast product, must be added the greater problem ... of profitable sale and distribution.

"Fruit is surely ... destined to be cheap and in over-supply; but if our finances suffer, we may console ourselves with the philosophical reflection that if our pockets are lighter, humanity wins."

Obstacles to Market Expansion.-The main obstacles to the expansion of eastern markets were considered to be: (1) high transportation rates; (2) slow and inadequate shipping service; (3) a tendency for the shipping companies to keep eastern. markets bare; (4) markets alternately bare and glutted because of unorganized shipment by competitive shippers; and (5) a tendency for eastern retailers to operate on wide margins, which kept prices at retail very high.

In the minds of the fruit producers, freight rates were perhaps the item of greatest importance as an obstacle to market expansion. The rates of $\$ 800$ per minimum car of 10 tons from central California to Chicago, the most important single market, seemed high. ${ }^{41}$ And since large quantities were reshipped by express from Chicago, ${ }^{42}$ the cost of getting a car of fresh fruit to eastern markets by fast freight and express was really in the neighborhood of $\$ 1,100 .^{43}$

In 1881 a fruit growers' convention ${ }^{44}$ appointed a committee to confer with railroad officials about lower freight rates on fresh fruit, but they accomplished nothing. ${ }^{45}$ In the fall of 1884 another committee was appointed. ${ }^{46}$ This committee presented a memorial to the railroad

41 Only three fruit cars might be sent with any one passenger train even at that rate. Cars might be sent by "slow freight" at $\$ 400$. But the refrigerator cars and the practice of loading such cars were still in the experimental stage. Hence losses were heavy on such shipments.

42 Hixson, J. M., in address before Fifth Fruit Growers' Convention, 1885. California State Board of Horticulture Biennial Report 1885-86:72. Also, Pacific Rural Press 30:10. 1885.

43 See editorial in: Pacific Rural Press 27:610. 1884.

44 First Fruit Growers' Convention Report. p. 23. December, 1881. The Fruit Growers' Convention, held under the auspices of the California State Board of Horticulture, was the first of a long series of conventions held annually or semiannually since that time. These conventions will be referred to frequently, since cooperative marketing was almost invariably discussed at these gatherings. The reports referred to were usually published in pamphlet form. Many of the papers were, however, published in the farm press of the time, particularly the Pacific Rural Press.

45 It did report the indefinite suggestion that the railroad company might be willing to reduce rates by 70 per cent of the amount of any profit which might arise from increased shipments resulting from such reduced rates. First Fruit Growers' Convention Report. p. 23. December, 1881.

40 This time three groups were represented. They were the Fourth Fruit Growers' Convention, the State Horticultural Society, and the State Viticultural Convention. Pacific Rural Press 28:353. 1884; and 29:61. 1885. 
officials arguing for a rate to Chicago of $\$ 400$ on cars attached to passenger trains. ${ }^{47}$ In the middle of March, 1885, the railroads announced a reduction to $\$ 600$ and $\$ 300$ on fast (passenger) and slow freights respectively. Growers were disappointed, but this doubtless spurred them on to further action.

Development of the California Fruit Union.-A suggestion was made at the May meeting of the State Horticultural Society, ${ }^{48}$ and again at the June meeting, that a growers' organization for marketing fresh deciduous fruit be formed. Hearty cooperation among leading orange growers was cited as having forced California oranges "to the front this season at Chicago." Concerted effort was needed to get railroad companies to give "reasonable rates." And, ran the argument, "As long as growers work through speculators they will remain in the background." The result was the appointment of a committee to draft a form of organization. ${ }^{49}$ The subject was fully discussed at several meetings. Finally, at the monthly meeting of the State Horticultural Society on August 28,1885 , it was decided to call a meeting of the fruit growers of the state, since the job of forming an organization was too great an undertaking for the Society. ${ }^{50}$ Such a meeting was held in San Francisco on September 24.

At this meeting various plans of organization and operation were proposed. Among them, A. T. Hatch, of Solano County, favored a state organization with "subordinate stations in California for collecting the fruit" and "... giving a single eastern dealer or firm entire charge of the distribution of the fruit in the East." 51 David Lubin, of Sacramento, urged a plan which would obviate the need of organization by getting the railway company to provide subdivisions in cars so that any grower could ship a quarter of a car. ${ }^{52} \mathrm{Mr}$. W. H. Aiken, of Santa Cruz, urged a state organization with local associations to assemble and pack the fruit. A minority of the resolutions committee favored the formation of an organization which would get lower freight rates, but which would leave individual growers free to send fruit to whomever they desired..$^{53}$

47 Pacific Rural Press 29:61. 1885.

48 Pacific Rural Press 29:541; 30:10. 1885.

49 Pacific Rural Press 30:4, 10. 1885.

50 Pacific Rural Press 30:188. 1885.

51 Pacific Rural Press 30:270. 1885.

52 Pacific Rural Press 30:270. 1885. He discussed this plan in detail later as "the accommodation car plan." See: Sacramento Record-Union for October 14, 1885. Briefer statement: Pacific Rural Press 30:342. 1885.

53 Statement made informally by M. M. Estee. Pacific Rural Press 30:278. 1885. 
Finally the following resolution, offered by the resolutions committee, was passed:

Resolved, That it is the opinion of the majority of your committee that the fruit growers should organize a corporation confiding the management of their fruit for eastern shipment to a duly qualified Board of Directors of said corporation for the protection of their mutual interest and the disposal of their produce.

Resolved, That the capital stock of said corporation shall be $\$ 250,000$ represented by 250,000 shares of $\$ 1$ each, and that the fruit growers shall have the privilege of subscriptions at the rate of one share of stock for each acre of bearing orchard and vineyard of shipping grapes, the same to be an operative capital fund for mutual protective purposes. 54

The Original Plan.-The committee on resolutions at the meeting of September 24 and 25 was made a committee on organization. ${ }^{55}$ It went to work vigorously, and on October 1 issued a circular outlining briefly a plan of organization, stating what it might accomplish, and asking for subscriptions to the proposed organization. The circular pointed out that quantities "ten times as large as the present sales" could be made on eastern markets if "well-selected, good-conditioned fruit" were placed there at sufficiently low prices to popularize it. It pointed out further that these results could be gotten only by thorough organization which would secure :

First: The proper selection and uniform reliable packing of all fruits and grapes for shipment.

Second: The grouping together of all such shipments so as to make up entire trainloads to points of central distribution (thence to be sent in separate carloads to their various allotted destinations) ...

Third: The distribution (of) such shipments to various consumption destinations, so as to keep each market supplied and none over-stocked...

Fourth: The reducing to a reasonable minimum cost of packages, charges, and commissions on making sales.

Fifth: The securing (of) prompt, accurate and reliable returns ...

Sixth: The securing (of) reliable information concerning erops available for shipment, condition of consumption markets, favorable points for introduction and making of new markets, new varieties advisable to be planted for extension of assortment and prolongation of season of shipments ...

Seventlı: The systematic control of the eastern shipment of fruits and grapes would, in a most important degree, free the markets for local and canning consumption ...56

54 Pacific Rural Press 30:270, 299. 1885.

55 Mr. A. T. Hatch resigned from the committee stating that he was not in harmony with it. He was replaced by A. Block. The organization committee thus consisted of W. H. Aiken, Santa Cruz; R. J. Trumbull, San Francisco; Abbott Kinney, Los Angeles; A. Block, Santa Clara; H. P. Livermore, San Francisco; F. C. De Long, Marin County; and M. M. Estee, Napa. (Pacific Rural Press 30: 278. 1885.)

56 Pacific Rural Press 30:299. 1885. 
At the adjourned meeting of fruit growers held in San Francisco on November 10 and 11 the committee reported further on the need of an organization. It reported that President Stanford of the Southern Pacific Company had offered to run special fast trains at $\$ 300$ a car (Pacific Coast cities to Chicago) if the growers organized so as to be able to supply 15 cars daily (10-ton minimum). On slow freight the rate would be $\$ 200$. The committee showed that during 1885 enough fruit had been shipped to make such rates available had the growers been organized. It further showed that eight-tenths of the shipments originated at Sacramento, and also that eastern market distribution was unsatisfactory ${ }^{5}{ }^{5}$ It then proceeded to outline its recommendation.

The committee emphasized the idea of creating a general organization for the whole state in order to concentrate the eastern shipments under one management. It recommended that not only owners of orchards and vineyards, but also cultivators of small fruits and vegetables who were shipping East should be allowed to become stockholders. It was hoped that the latter would find a good market for their products if they could ship through the proposed Union and that they would facilitate the making-up of trains by furnishing additional freight.

In order to assure the retention of control in the hands of the growers, the committee proposed that the ownership of stock should be restricted to fruit growers and issued on the basis of acreage. Shares should be transferable only to persons qualified to become stockholders. Furthermore, voting by proxy should be restricted.

The committee recommended that dividends on stock be limited to 6 per cent, that 2 per cent of the net earnings be placed in a reserve fund, and that all remaining profits be returned to stockholders in accordance with the amount of produce shipped through the Union.

Three possibilities of selling were proposed. In the first place, the growers were to be allowed to sell to the Union. In the second place, they were to be entitled to ship and sell through it. In the third place, those growers who were also shippers on their own account were to be able to use the shipping facilities of the Union without selling to or through it. In this latter case, it was thought advisable, however, to have the Union exercise advisory supervision to prevent too much fruit going to the same place.

It is also interesting to note that the committee sought to enlist support for its plan by calling attention to the plan of organization of the Florida Fruit Exchange, which had been established in February, 1885.

5i Pacific Rural Press 30:401-402. 1885. 
The plan worked out by the Florida fruit growers was somewhat similar to that promulgated by the California committee. ${ }^{58}$

At the close of the first day the meeting approved the committee's recommendations and appointed a committee on by-laws. ${ }^{59}$ At the second day's session, by-laws were reported and adopted. Articles of incorporation had apparently been filed at once. Subscriptions for stock were at once accepted and a set of officers elected ${ }^{60}$ for the new organization called the California Fruit Union.

At the Fifth Fruit Growers' Convention, held at Los Angeles on November 17, 18, and 19, 1885, Horatio P. Livermore, who had been a member of the organization committee and one of its leaders, explained the plan to the fruit growers of the southern part of the state. ${ }^{61}$ Livermore afterwards became the first president of the new Union. The hope was to induce the growers in southern California to join the Union. Livermore advanced the idea that citrus and deciduous fruits would fit well together, since the former would use the organization in the summer months and the latter mainly during the winter. A committee of southern fruit growers was then appointed to consider the California Fruit Union. ${ }^{62}$ The southern members of the convention thought, however, that for the time being the best thing for them to do would be to set up a separate local organization and after it had been brought into existence, to consult then with the California Fruit Union concerning the question of working together to mutual advantage ${ }^{63}$ It is interesting to note that the idea of a joint sales force for citrus and deciduous fruit later materialized. (See footnote 158, page 48.)

Modification of the Original Plan.-The original plan outlined above was based on two main ideas. First, it was intended to make the Union an association owned and controlled by the growers. Secondly, it was desired to use it as a means of eliminating the control of the fruit business by dealers who were considered to be working only in their own interests. However, the plan of organization and operation as it stood at the beginning of the existence of the Union was soon considerably changed.

58 Pacific Rural Press 30:342-3. 1885.

59 This committee consisted of L. F. Rose, M. M. Estee, H. P. Livermore, G. W. Hancock, A. Kinney, T. W. Madeley, L. A. Buck, and A. Block. Pacific Rural Press 30:402. 1885.

60 See original by-laws, list of subscribers, and list of directors. Pacific Rural Press 30:397. 1885.

61 California State Board of Horticulture, Biennial Report 1885-86:78-90.

62 California State Board of Horticulture, Biennial Report 1885-86:97.

63 Pacific Rural Press 31:204. 1886. 
The first important modification was made at the beginning of $1886,{ }^{64}$ when the trustees made their decision with reference to the eastern representation of the organization. The general understanding among the stockholders seems to have been that a number of responsible fruit firms or agents were to be appointed at the different eastern markets. Instead, the trustees decided on March 10 to make Porter Bros. \& Company, of Chicago, exclusive agents for the entire district east of the Missouri River. ${ }^{65}$ This was done in spite of the fact that many eastern firms offered their services at much lower commission rates than Porter Bros., who demanded 10 per cent. ${ }^{66}$

There were two main reasons for the appointment of Porter Bros., even though other firms had offered to do the work for less. First, most of the other firms were in position to operate only in restricted territories. Porter Bros., on the other hand, already had agents and connections in practically every large market. Secondly, and most important in the minds of many of the leading growers who were also shippers, was the realization that by making this firm their agent they would eliminate the danger of competition from the then only strong rival organization in the field. ${ }^{67}$ While this measure seemed to involve certain immediate advantages, it likewise created the fear that it would endanger the attempt to build up a strong growers' association because the shipping company employed as sole agent could firmly entrench itself and leave the cooperative weak. As subsequent events showed, the decision led to opposition and distrust among the fruit growers and supplied material for counter propaganda by competing shippers.

64 As a matter of fact some amendments of the by-laws made at the first annual meeting of the California Fruit Union on January 20, 1886, were of importance. Section 10 had provided that growers might sell to the Union fruit "duly loaded on the cars." This section was amended to provide that stockholders might name consignee and destination on full cars shipped through the Union and that the Union be allowed to purchase no "fruit or vegetables from anyone." Pacific Rural Press 31:112. 1886.

65 See copy of contract and outline of discussion leading to its signature, and also editorials on this action. Pacific Rural Press 31:308, 296, 272. 1886.

66 As a result of this decision Livermore, who led the opposition to the appointment of a single agency, resigned as president. While he stated that personal affairs prevented his continued service, the action of the trustees was said to be "contrary to his beliefs" and "offensive to his business judgment." Pacific Rural Press 31:276, 308. 1886.

67 Adams says that they made it "the principal eastern agent of the Union, on condition of its refraining from direct seeking for business from growers, at lcast in the districts where the Union was strong." (Adams, Edward F. Modern farmer, p. 454. San Francisco. 1899.) This is not clear from the contract. Section 8 of the contract did, however, provide: "That it [Porter Bros.] will not purchase any other products directly or indirectly when in the opinion of the General Manager of the California Fruit Union, the sale of the same may be detrimental to the interests of said California Fruit Union. . . " Pacific Rural Press 31:308. 1886. 
The second important change in the original plan occurred a year later at the meeting of the stockholders in January, 1887, when the by-laws of the Union were so amended as to admit to membership nonproducers engaged in buying and shipping fruit. ${ }^{68}$ The proposal to admit the dealers had already been made at the time of organization and again at the meeting of the stockholders in 1886. This decision was motirated by the experience during the first shipping season of 1886 and by the recommendations submitted by Harris Weinstock, ${ }^{69}$ who, on his own initiative had made a trip to the East in the fall of that year in order to study the marketing of California fruit there. Weinstock found that although the Union had made efforts to regulate fruit shipments, marketing conditions in the East had not been improved. On the contrary, severe competition had taken place in the East between the California Fruit Union and the California Fruit Growers' Association, ${ }^{70}$ a competing organization established by fruit shippers and a number of growers to avail themselves of the lower freight rates offered by the railroads on shipments of 15 -carload trains. The shipment of special fruit trains simultaneously by both organizations had repeatedly oversupplied the eastern markets even more seriously than in previous years, and this oversupply had again led to disastrous price cutting and low returns to the California growers. In addition, Porter Bros. and other eastern concerns had further stirred up animosities by charging each other with price-cutting to oust competitors. ${ }^{71}$ It was to avoid a repetition of this evil that Weinstock made his proposal that the California Fruit Union and fruit shippers should combine their interests. This proposal was discussed at the Fruit Growers' Convention at Sacramento in November, $1886 .{ }^{72}$ Since the majority of those present favored it, the Convention advised the Union to adopt it. When the proposal was subsequently considered at the annual meeting of the stockholders in January, 1887, the by-laws were amended to admit nonproducing shippers to the Union upon the purchase of 200 shares of stock. ${ }^{73}$ By permitting

68 Pacific Rural Press 33:90. 1887.

69 Weinstock was a merchant who operated a store in Sacramento in partnership with David Lubin who afterwards became famous in connection with the establishment of the International Institute of Agriculture in Rome. They also owned a vineyard in the vicinity of Sacramento for some years. Both Weinstock and Lubin became interested in the improvement of marketing conditions for deciduous fruits because they felt that their own mercantile business would prosper if the growers were successful.

i0 This organization will be discussed later (page 24).

71 Pacific Rural Press 32:171. 1886.

72 California State Board of Horticulture, Biennial Report 1885-86:276-277.

i3 Pacific Rural Press 33:91. 1887. 
this combination of growers and shippers, the leaders of the Union departed from the ideals for which many of them had fought. They considered the combination of growers and dealers as a necessary compromise.

The Adoption of the Auction Plan.-Weinstock's trip to the East in 1886 had still another important effect. It led to the adoption of the auction system by the Union. ${ }^{74}$ Weinstock had written articles for the Pacific Rural Press describing market conditions and the auction system in detail. ${ }^{75}$ This system was not new. It had already been developed in the sale of imported oranges in the United States. It had later been adopted by the Florida fruit growers, who, after successfully trying it in Boston, had made arrangements in 1886 to use the plan in New York City.

Weinstock had become convinced that this system would also prove satisfactory in selling California fruits in the East. He therefore included in his recommendations to the Union the proposition to adopt the auction plan. ${ }^{76} \mathrm{As}$ a result the annual session of the stockholders in January, 1887, recommended that the Board of Trustees should try it out. ${ }^{77}$

When the Union began to experiment with the auction plan in the New York City and Boston markets it met some opposition on the part of commission firms. Porter Bros., who were representing the Union at Chicago, were accused of purchasing large quantities of fruit on the demoralized markets of Chicago during the season of 1887 and sending it to New York for private sale while the Union was using the auction. They were said to have sold $\$ 140,000$ worth of fruit there, while the Union sold only about $\$ 55,000$ worth. The New York agents of the Union admitted, however, that the New York market was not really "tested" by its receipts. Mr. Porter and others who opposed the establishment of the auction in Chicago claimed that it would slow up selling there, since much was sold for reshipment before it arrived. ${ }^{78}$ Nevertheless, the experiments in those cities turned out so satisfactorily that, at the beginning of 1888, the stockholders of the Union instructed the Board of Trustees to apply the auction plan in Chicago as well. ${ }^{79}$ Following

74 Pacific Rural Press 33:91. 1887.

75 Pacific Rural Press 32:346, 366. 1886.

76 California State Board of Horticulture, Biennial Report 1885-86:277.

77 Pacific Rural Press 33:91. 1887.

is Pacific Rural Press 35:229, 330. 1888.

79 Pacific Rural Press 35:96. 1888. However, there was enough difference of opinion to lead the trustees to refer the matter to growers by circular. Decision was reached late in May. Pacific Rural Press 35:488. 1888. 
the experience of the first two years, the officers of the Union became even more convinced that they had moved in the right direction when they adopted this sales method, with the result that they arranged for auctions in several other markets.

The two chief advantages claimed for the auction were that it increased competition among buyers and lessened the danger of combinations among them. At one place and at certain hours, large and small buyers were brought together and made to compete with each other for their supplies. These advantages were later somewhat lessened when rival auctions were established at several markets and when several of the auctions became so-called "closed auctions," to which only members of a certain class of dealers or certain firms were admitted. ${ }^{80}$

Eastern Representation.-Porter Bros. held the sole agency of the markets east of the Missouri River for only one year. In April, 1887, the Board of Trustees instructed the manager to appoint agents immediately at Omaha, Kansas City, St. Louis, St. Paul, Boston, New York, Philadelphia, and Baltimore, and at his discretion at certain other markets. ${ }^{81}$ Every representative was required to give bond and to handle no fruit not shipped through the Union. To get a better control over the activities of the eastern agents the question of employing a general agent was discussed in $1887 .{ }^{82} \mathrm{~A}$. T. Hatch, president of the organization, was finally sent East. During the season of 1888, actual general supervision was provided in the East by the presence of Harris Weinstock, one of the directors. ${ }^{83}$ There was probably no general supervision in later years.

Shipments and Sales Receipts.-A variety of fruit was shipped East, including apricots, plums, grapes, peaches, cherries, pears, quinces, figs, almonds, and currants. The number of individual shippers increased from 127 in the first shipping year, 1886, to 895 in 1893; shipments increased from about 400 cars to 3,000 for these same years. ${ }^{84}$ Of the latter about 2,400 went to Union agents and the remainder were sold by members to concerns in cities where the organization had no represen-

\footnotetext{
80 See address of Harris Weinstock in Eighteenth Fruit Growers' Convention, Official Report.p. 19-20. 1894.

81 Pacific Rural Press 33:360. 1887. Porter Bros., however, represented the Union in Chicago in 1887 and later years. After 1887 they were required to use the auction plan. Pacific Rural Press 35:488. 1888.

82 Pacific Rural Press 33:241, 334. 1887.

83 Pacific Rural Press 35:488. 1888.

84 These and the following figures, if not otherwise stated, are taken from the annual reports of the Union, which were published in the Pacific Rural Press and the California Fruit Grower.
} 
tatives. ${ }^{85}$ Gross sales grew steadily from a third of a million dollars in 1886 to two million dollars in 1893. A large portion of these receipts went to the transportation companies who were always said to obtain too much.

In 1889 and 1890, the Union shipped about two-thirds of the green fruit which left California. The only other large shipper was the Earl Fruit Company. According to Weinstock, for several years these two agencies handled about 90 per cent or more of the California shipments. ${ }^{86}$ Later many new firms entered the fruit-shipping business with the result that the relative amount of produce dispatched by the Union decreased.

Financial Operations.-At the beginning the commission deducted by the California Fruit Union from the gross receipts at terminal markets was 10.0 per cent, but in 1891 it was reduced to 7.0 per cent. Out of these charges, the commission agents as well as the rebates and dividends to growers, were paid. Net commission rates actually amounted to 8.7 per cent in 1889 , and 6.5 per cent in 1893 . The actual expenses of conducting the Union were very small, about 0.6 per cent.

The Union received from payments on capital stock only $\$ 15,578$. About half of this was spent to meet operating costs during the first season. The rest was probably spent on organization and propaganda work. No information is available concerning disposition of later payments on stock. During the time of its existence the organization returned $\$ 105,000$ to its stockholders in the form of dividends, rebates, and on account of claims for delay and damages collected from transportation companies. ${ }^{87}$

Membership and Management.-The number of subscribers to the capital stock of the Union who actually paid the required installments stood at 217 at the end of the first year. In May of 1886, it had stood at 715 , subscribing a total of 15,143 shares. A large number failed to pay additional installments when called upon to do so. In January, 1894, shortly before the dissolution of the Union, the number was 595 holding 14,510 shares. This figure was far less than the authorized 250,000 shares (par value $\$ 1.00$ ). The members did not all use the facilities of the Union. During the first year it sold for only 127 men. Some of the rest

85 In May, 1888, the board voted to allow members of the Union to ship on direct sale to any party, provided the shipper paid the Union $\$ 30$ a car towards its expenses and guaranteed as much of the freight as the Union may have prepaid. California Fruit Grower 1(1):7. 1888.

86 Weinstock, Harris. Fighteenth Fruit Growers' Convention Official Report. p. 17. 1894.

8i Number of subscribers and financial statements taken from: Pacific Rural Press 33:90. 1887; and 47:44. 1894. 
doubtless sent cars on Union special trains or sold cars with the Union's approval in markets where the Union was not represented. In the last year the number of shippers was actually larger than the number of shareholders, but some of these doubtless were the patrons of shipper members. The Union did not require growers to sign contracts.

The active directorate of the Union throughout its history consisted of large growers and shippers, who, before entering the Union, had gained experience in the eastern markets. P. E. Platt, of the W. R. Strong Company of Sacramento, L. W. Buck, of Vacaville, a large grower and shipper, and Harris Weinstock, merchant and grower, were among those most active in the management of the Union during much of its existence.

Struggle with Rival Organizations.-During its first years of existence the Union experienced interference and competition from several rival organizations which endeavored to draw growers and business away from it. The first rival was the California Fruit Growers' Association. This organization, already mentioned (page 20) was established in March, 1886, ${ }^{88}$ as a result of the efforts made by the independent shippers to obtain the same reduced freight rates through large shipments in special fruit trains as those obtained by the Union. It will be remembered that a proposal was made at the first annual meeting of the Union in January, 1886, to admit the independent shippers to the Union and that this proposal had been defeated. In consequence. the shippers under the leadership of R. D. Stephens, of Sacramento, decided to organize themselves.

The California Fruit Growers' Association was a growers' and dealers' organization with a capital stock of $\$ 20,000$, divided into 100,000 shares (par value 20 cents). Harris Weinstock, David Lubin, R. D. Stephens, and E. T. Earl were among those who took stock. ${ }^{89}$ The organization work proceeded so quickly that the association shipped the first special fruit trains to the East prior to the beginning of such shipments by the Union..$^{90}$

The operations of the California Fruit Growers' Association undoubtedly interfered greatly with the program of the California Fruit Union

88 California State Board of Horticulture, Biennial Report 1885-86:27.

89 Pacific Rural Press 31:334. 1886.

90 The California Fruit Growers' Association sent its second special train on June 30, 1886. Pacific Rural Press 32:45. 1886. Some time later President A. T. Hatch of the Union stated that the Union had not yet sent special trains because members were selling to those who were trying to break up the Union. Pacific Rural Press 32:55, 261. 1886. 
during its early years. The officials and members of the Association tried to influence the growers not to join the Union and capitalized as much as they could on the fact that the Union was being represented by Porter Bros. After the Union had opened its doors to the independent shippers in the following year, most of the large dealers joined its ranks, though the rival organization continued in business for at least one more season. ${ }^{91}$

In 1888, another group of dealers and growers, including the Earl Fruit Company, formed a second rival organization, the Grower's' and Shippers' Association..$^{22}$ This was followed the next year by the Golden Gate Fruit Association, which was again joined by a number of growers and shippers dissatisfied with the California Fruit Union. ${ }^{93}$ A. T. Hatch, who had succeeded Livermore as president of the Union, became the head of the Golden Gate Fruit Association, which again included E. T. Earl, of the Earl Fruit Company. According to a letter sent to the Pacific Rural Press by R. H. Chinn, a fruit grower of Vacaville who shipped through the organization, its operations were disappointing. ${ }^{94}$ Undoubtedly, it also hampered the growth of the California Fruit Union and added to the confusion among the growers. It probably did not operate for more than one season.

Achievements of the Union.-Although the Union faced the competition of rival organizations and did not receive the expected support of the majority of the growers, it promoted the marketing of fresh deciduous fruit in various ways. While primarily serving a small number of large fruit growers and dealers, it also brought some indirect advantages to the growers on the outside. It took an active part in getting from the railroad companies better service and lower rates. It undertook aggressively the widening of eastern markets and the improving of marketing methods in the East. It brought about the application of the auction method to the sale of fresh deciduous fruit in the larger eastern markets

91 H. A. Fairbanks, Secretary of the Union, in a statement to stockholders in April, 1887, referred to the two organizations in the field as "now consolidated." Pacific Rural Press 33:334. 1887. On April 15, however, the California Fruit Growers' Association met at Sacramento and decided to continue in business, but to sell at home. Pacific Rural Press 33:360. 1887. In 1889 no other organization than the Union sent special trains. Pacific Rural Press 39:68. 1890.

92 Pacific Rural Press 35:541. 1888.

93 Pacific Rural Press 37:533. 1889.

94 Chinn claimed that the organization had not been incorporated and that it was controlled by the Earl Fruit Company. This company, he said, handled in an arbitrary way the small lots sent to Sacramento for reloading. Instructions were withheld and payments delayed. Seven per cent commission and, in addition, $2 \frac{1}{2}$ cents a box for loading, telegrams, and refrigerating ears were charged. See: Pacific Rural Press 38:418-19. 1889. 
and fought combinations of dealers who were alleged to have hampered the development of the widest possible markets. As a result of its operations, higher prices were doubtless obtained in the distant markets as well as in the home markets, the latter being relieved of large quantities of fruit which would otherwise have depressed prices in California. Furthermore, it supplied valuable market information at a time when growers would otherwise have been poorly informed. ${ }^{95}$

The Union also fostered the development of local organizations. A number of locals were formed ${ }^{96}$ at the suggestion of officials of the Union, who repeatedly urged growers to get together at local points in order to obtain carload freight rates and to improve the handling of their fruit.

Shortcomings.-Against these achievements at least three serious shortcomings must be pointed out. In the first place, the Union did not succeed in uniting the California growers of fresh deciduous fruits in a cooperative enterprise owned and controlled by them. In the second place, it failed in one of its major objectives which was to concentrate the eastern shipments under one management. Even the admission of the independent shippers did not accomplish this objective. In the third place, it was sometimes slow to act or even passive when faced with important problems.

To create a strong growers' organization was originally, as will be remembered, one of the important aims of the Union. But the majority of the growers did not come in nor did the control of the association remain in the hands of the growers. It is difficult to say whether a more aggressive membership campaign would have brought in more growers, with a competing organization actively in the field denouncing the Union and soliciting business for itself. At any rate, when the shippers were taken in, in 1887 , it became still more difficult to get a large share of the growers to join. Even the employment of Porter Bros. as sole agents in the markets east of the Missouri River in 1886 was partly necessitated by lack of grower support, although that act further increased the difficulty of getting widespread grower support. The general enthusiasm which had existed in the year of organization soon died out because of lack of confidence, insufficient insight into the marketing problem, inertia on the part of growers, and hasty acceptance of counter-

95 See editorial in: California Fruit Grower 1(3):5. 1888.

06 See, for example, the last two annual reports. Pacific Rural Press 45:73. 1893; and 47:44. 1894. Just how many locals there were, and how many worked through the Union is not known. These were not members as organizations, but rather organizations of Union stockholders located in the several localities. Only one of these organizations is now in existence-the Florin Fruit Growers' Association organized in 1890 . 
propaganda. ${ }^{97}$ Instead of joining the Union, the majority of the farmers continued to ship through the independent dealers whose activities they had criticized and condemned. They thereby strengthened the position of rival organizations expecting, however, that somehow it would be demonstrated to them in what way a growers' association could effectively serve them. Last, but not least, the admission of the dealers and the passivity of the grower members enabled the former to gain and hold the control of the Union. 'True enough, a change could only be accomplished by growers' action, but, as Adams ${ }^{98}$ pointed out, the bulk of the grower members made little or no effort to influence the course of their organization.

As far as the failure of the Union to concentrate the eastern shipments under one management is concerned, it was largely due to aggressiveness, jealousy, and suspicion among the shippers. Although most of them had joined the Union in 1887, a split had occurred and a rival organization had formed before the shipping season of 1888 arrived. Moreover, in the early nineties improvements in refrigerator cars had given small shippers an opportunity of building up fruit-shipping businesses of their own.

As to the third shortcoming-slowness and passivity when quick decision and aggressive action were needed - the difficulty arose partly out of diversity of interest, and partly out of sincere differences on how certain problems should be met. Large grower-shippers undoubtedly considered various proposals for organization or operation from the point of view of both the prices for their own products and the additional gains from the shipping business. In some cases the shipping

97 "All were anxious to see the Union established, but few were willing to risk the dollar per acre. The great majority of the growers remained idly at home waiting for some one no more interested than they to come and talk to them ... No one was willing that the plan should be given up, but nearly all were determined that some one else should bear the burden... As the business increased, new shipping houses naturally made efforts to get in, with no care whatever for the interests of the growers, which imperatively demanded, in this brand of industry, one directing head controlling the entire volume of business. These new firms found that their readiest means of obtaining a foothold was to instill into the minds of growers a suspicion of their own agents; the notion was spread widely that the eastern agents controlled the business and that, as a matter of fact, it was not their own agency which the growers were supporting, but a private forwarding house, and they were so utterly silly that, with that notion once in their heads, their strong impulse was to at once rush into the arms of some opposition concern." Adams, Edward F. Modern farmer. p. 453, 455. San Francisco. 1899.

98 "As a matter of fact, it was impossible for any but the growers themselves to control the Fruit Union, if they would only take the trouble to attend the annual meetings and vote for directors of their choice, or place their proxies with those who would do so, but they did neither; the annual meetings often had to do business without a quorum, or to go without doing business at all." Adams, Edward F. Modern farmer. p. 456. San Francisco. 1899. 
business was doubtless the dominant interest. In either case these men opposed such proposals as would give the Union the power demanded by those who would make it the controlling and grower-controlled organization.

The idealists of the group likewise differed, not only about plans which would be most effective, but also about the degree to which the Union should depart from its ideals to meet practical situations.

When the Board of Trustees of the California Fruit Union announced on March 12, 1894, that the Union would retire from the field for the season as a fruit-shipping association, there was scarcely a murmur of objection from fruit growers. This seems surprising. The business of the Union had increased each year, and the report made at the last annual meeting had certainly not been pessimistic. The Union had been formed during the hard times of the middle eighties. Total out-of-state shipments had run at about 50 million pounds a year from 1886 to 1889. Times had gotten better and improved marketing had helped matters. Then in 1890 shipments jumped to 68 million pounds. The next year they went to 101 million, in 1891 to 119 million, and in 1893, the Union's last year, to 160 million. However, relative to the total out-of-state shipments, the Union's buisiness had decreased from about 44 per cent in 1889 and 1890 to about 30 to 33 per cent in 1891 to 1893. Such a relative decline should probably not have mattered much had other things gone well. But total out-of-state shipments had been increasing more rapidly than the markets would absorb them even with such improvements as had been made in marketing methods. Moreover, a serious business depression had set in in the summer of 1893. 'The Union's returns to shippers amounted to about $\$ 34$ per ton of packed fruit..$^{99}$ It was perhaps only natural that shippers should blame the management.

The ideal that has been pictured during the organization period of 1885 and early 1886 had long been shattered. The Union had in reality become little more than a glorified clearing house. Moreover, the operations of the Union had been such that most of its benefits went to members and nonmembers alike. It is not surprising, then, that the passing of the Union caused little stir. There were, of course, some comments. A stockholder wrote an anonymous letter to the editor of the Pacific Rural Press urging the reorganization of the Union. ${ }^{100}$ The editor had, however, already published an editorial in which he concluded that: "We cannot regard the cessation of the work of this association as of

99 Author's calculations.

100 Pacific Rural Press 47:243. 1894. 
any particular moment." 101 The editor of the California Fruit Grower, ${ }^{102}$ however, commented that "... it is safe to predict that more or less demoralization will ensue... [in the market]." The directors obviously sensed the members' feeling, for the latter could, of course, have called a meeting and elected a new board of directors, but they did not. One reason why even the leading growers remained passive was that a new marketing movement was already under way which some had urged should serve the entire fruit industry, although it had started in the dried-fruit industry. ${ }^{103}$

\section{THE CALIFORNIA FRUIT GROWERS' AND SHIPPERS' ASSOCIATION}

After the California Fruit Union had gone out of business in the spring of 1894 no new central organization was formed immediately. But, before the year ended, new efforts were made to overcome the disadvantages of uncoordinated action. These efforts resulted in the establishment of the California Fruit Grower's' and Shippers' Association, an organization which to some extent replaced the California Fruit Union and maintained the combination of fruit growers and dealers in somewhat similar form for a number of years.

Steps Leading to Organization.-The shipping season of 1894 ended with poor results and widespread dissatisfaction among the growers and shippers. Harris Weinstock expressed the situation by saying: "We find ourselves in 1894 back again to similar conditions that existed in 1885 and 1886-with this difference: In those years about 1,000 carloads glutted the markets of the East; this year it takes nearly 7,000 carloads to do it." ${ }^{104}$ In looking for the causes it was recognized, on the one hand, that the general business depression of that year had reduced the demand for fruit in the eastern cities and, on the other hand, old and new defects in the marketing system were in part responsible for low returns.

The ensuing discussions of the marketing system drew attention to four main defects, three of which had been discussed long before. The first of the older arguments was that proper and intelligent regulation of shipments was lacking. This could be well illustrated by the new

101 Pacific Rural Press 47:201. 1894.

102 California Fruit Grower 14(11):201. 1894.

103 The California Fruit Exchange, which was organized in 1893. (California State Board of Horticulture, Biennial Report 1893-94:412. See also: Adams, Edward F. Modern farmer. Chap. VI. San Francisco. 1899.) This organization was recognized as "the authorized representative of the fruit growers of California." (Eighteenth Fruit Growers' Convention, Official Report. p. 26. 1894.) 1894. 
unfavorable events in 1894. The markets in the East had again been glutted on account of reckless and indiscriminate shipments so that California producers had not even gained an advantage from the short eastern fruit crop of that year. Furthermore, instead of distributing the fruit to a large number of cities direct, a few large centers had again received a large percentage of the shipments.

The second older argument was that the railway service was unsatisfactory, and that excessive refrigerator and local transportation charges were made. The third traditional defect was the indiscriminate consignment of unsold fruit to eastern concerns. Since growers had received advances from the consignees in most cases the fruit was frequently sold on weak markets to protect such advances even though growers got nothing further. Conditions were aggravated by the fact that commission men were often at once purchasers on their own account and consignees of the same class of fruit. The fourth defect lay in the abuses which had crept into the auction system. There was repeated criticism of the so-called "closed auctions" and of the opening of more than one auction in certain cities. It was further charged that in some instances dealers had entered into collusion concerning the amount they should bid for certain lots.

United effort of all interests was generally looked upon as a means of improving marketing conditions. How this should be attained was the main theme of the Fruit Growers' Convention in November, 1894.

Two Plans.-At this convention two plans of organization came up for consideration. One of them was the plan drafted by Harris Weinstock. ${ }^{105}$ It provided that the fruit growers and dealers should establish another joint organization. It proposed that the auction system should be maintained but that the abuses which had developed within that system should be corrected. This correction was to be brought about by the establisment of one auction room only for each city, with the provision that the auctions be open to all buyers, large and small. It also recommended that the new organization should create a Bureau of Information to assist in the regulation of shipments. This bureau was to be supported by all persons engaged in shipping fruit and to be entrusted with the task of issuing daily bulletins on the market situation. ${ }^{106}$ The organization was further supposed to undertake other

105 Eighteenth Fruit Growers' Convention, Official Report. p. 20. November, 1894. It will be recalled that Weinstock led the fight which brought the dealers into the California Fruit Union in 1887.

106 The idea of establishing a Bureau of Information, which Weinstock began to urge at the beginning of 1894, was probably based on the example set by the information service which the Santa Clara Fruit Exchange had developed in 1893. See: Pacific Rural Press 46:330.1893; and 48:182. 1894. 
measures which might be considered suitable for the promotion of fresh-deciduous-fruit sales.

The other plan was presented by the proponents of the Exchange System $^{107}$ which had recently been developed among the citrus and dried-deciduous-fruit growers. Mr. E. F. Adams, Manager of the California Fruit Exchange, which had been organized among the driedfruit growers late in December, 1893, urged the extension of that organization into the fresh-deciduous-fruit field. ${ }^{108}$

For the deciduous-fruit growers this plan meant that they should band themselves into local associations or "exchanges" which, after a sufficient number of such exchanges had been created, should become members of a State Exchange. This State Exchange was not only to be the general sales agent of the local fresh-deciduous-fruit exchanges, but also of the exchanges handling dried fruits. It was to develop the eastern ontlets, appoint representatives, and supply market information for all. ${ }^{109}$ For the deciduous-fruit growers, this plan meant further that

107 The term "Exchange System" as used by Adams and others, refers to the plan under which local associations are formed and these organized as parts of a central organization. Repeatedly, however, the name was applied to an entirely different form of organization which was proposed for the use of the dried-fruit growers, a form based on the butter and cheese boards, then at the height of their usefulness in the East and Middle West. Thus at the Eighteenth Fruit Growers' Convention in November, 1894, Mr. F. M. Righter, of Campbell, urged the adoption of a plan based on that of the Elgin Board of Trade. (Official Report, p. 41-45. See also: Pacific Rural Press 49:22. 1895.) It was urged by W. R. Nutting and actually attempted in connection with the sale of raisins at Fresno in 1911. (See: Pacific Rural Press 82:143, 436-7. 1911. See also address by W. R. Nutting, Forty-Second State Fruit Growers' Convention, Proceedings. December, 1912. California State Commissioner of Horticulture, Mo. Bul. 2:504-508. 1913.)

108 Eighteenth Fruit Growers' Convention, Official Report. p. 32-33. November, 1894.

$109 \mathrm{E}$. F. Adams, who figured as one of the foremost leaders in the movement for the establishment of the Exchange System, explained these points at the 1894 convention in the following words: "There are a few who suppose that there should be separate state organizations for the two interests (of dried and fresh fruit) ... The great mass of fruit growers, however, are interested in both branches ... That the two lines must be under different salaried management is evident, but the same directory, the same capital, the same eastern agency, the same general office, the same information, the same organizers, and the same many things will do for both, and it is folly to proceed otherwise ...

"The State Exchange, as the agent of the local exchanges, would appoint all the brokers necessary in all markets, and supply their names to all contributing exchanges, who would push the sales of their own goods through these brokers, missing no chance of a better sale at home. Each broker will contract to supply the State Exchange with information asked for, the State Exchange to repeat the same by daily private bulletins to the local exchanges. Whatever further concert of action was thought desirable would be arranged through the State Exchange, and no one but those interested know anything about it. There would be a regular annual convention of delegates of local exchanges . . . The State Exchange would be the agent of the local exchanges, and do what they wished and keep their business to themselves like other business people." Eighteenth Fruit Growers' Convention, Official Report. p. 32-33, 34. November, 1894. 
they should again join a movement for the creation of a cooperative marketing system owned and controlled by growers only. In other words, no combination of growers and dealers should take place. ${ }^{110}$

The guidance of the movement for the establishment of a State Exchange was in the hands of the officials of the California Fruit Exchange. ${ }^{111}$ This organization had been formed late in 1893 with the idea that it should first lead in the organizational work and later become the general agent of the local exchanges. ${ }^{112}$ As long as the California Fruit Union was in existence the Exchange had devoted its attention primarily to the organization of the dried-fruit industry. It had stayed out of the field of fresh deciduous fruits expecting, however, that before long the Union would become part of the new system.

In looking over the situation in the deciduous-fruit industry, the directors of the California Fruit Exchange recognized, on the one hand, that they needed both financial support from the growers and time to carry out the organizational work. On the other hand, they saw that something had to be done immediately for the deciduous-fruit industry. They, therefore, supported Weinstock's plan as an appropriate device for temporary relief. In the meantime, they intended to go ahead with their plan of organizing the different branches of the fruit industry and to devote much more energy to the task of bringing the deciduousfruit growers together in local associations. It was contemplated that the California Fruit Exchange was to do most of the organizational work, but that the organization proposed by Weinstock would lend its support in building up local associations for the marketing of fresh deciduous fruits.

The idea was again urged at the Fruit Growers' Convention of November, 1895. At that time, however, it was pointed out that no help could be expected from the Fruit Growers' and Shippers' Association because its interests and those of the Exchange "lie right in opposite directions." A. R. Sprague, later to become first manager of the California Fresh Fruit Exchange, was particularly insistent at the November meeting of 1895 that a more aggressive campaign be inaugurated for

110 Adams made this very clear by saying: "Our associations, State and local, will need to deal with them [the existing independent firms now engaged in the fresh-fruit trade] . . . but the seeds of sure destruction are sowed and certain to grow in any organization which contains adverse interests within its own bowels." Fighteenth Fruit Grower's' Convention, Official Report. p. 33. November, 1894.

111 This organization must not be confused with the present California Fruit Fxchange. The latter was originally organized in 1901 as the California Fresh Fruit Exchange. The present name was not adopted until 1907, over a decade after the older organization of that name had ceased to function.

112 Pacific Rural Press 47:3-4, 7-8, 44. 1894. 
the formation of local associations by local people, including particularly the members of the convention. ${ }^{113}$

Weinstock's proposal, unanimously adopted by the Fruit Growers' Convention of 1894, was in the form of the following resolutions :

WHEREAS, Owing to certain causes the shipping of green fruits to the markets of the East has more recently proven highly unprofitable; and whereas, a continuance of these causes must mean ruin to untold numbers of growers and must seriously threaten the future of the green fruit industry of our state; and whereas, we have reasons to believe that by united action on the part of shippers and growers many of these causes may be removed and certain existing evils overcome; be it therefore

RESOLVED, That without reference to any great popular movement to unite the fruit growers of the state in one organization for general purposes, but in addition and auxiliary to that movement, this convention recommends and earnestly requests the classes of growers and shippers above mentioned to proceed forthwith to organize themselves into a union to be known as the Fruit Growers' and Shippers' Association of California; and be it further

RESoLVED, That the purposes of the proposed association shall be: (1) the establishment of a Bureau of Information to regulate distribution; (2) to establish one auction-room only in each city; (3) to make such auction-room open and free to all buyers; (4) to do all such other things as may be conducive to the best interests of the fresh-fruit industry of California; and be it further

RESOLVED, That the President of this convention be requested to appoint a committee of five, which shall represent all the above classes of shippers, for the purpose of taking steps to carry the above resolution into effect; and be it further

RESOLVED, That the California Fruit Exchange, as it proceeds in its work of organization, be requested to make the importance of maintaining such association very prominent, and to impress upon all growers the necessity of strongly supporting it in all ways; and be it further

RESOLVED, That the members of this convention hereby pledge themselves to give such association, when formed, our continuous and hearty support.114

Following the adoption of the resolution a committee was appointed to set up the organization of fruit growers and dealers. This committee consisted of N. R. Salsbury, of Porter Bros.; E. T. Earl, of the Earl Fruit Company ; Frank H. Buck, of Vacaville ; David Reese, of Florin ; J. D. Mathews, of Newcastle ; and Harris Weinstock. ${ }^{115}$

Establishment of the New Combination.-The new combination proposed by Weinstock was organized in February, 1895, ${ }^{116}$ for the purpose

113 Nineteenth Fruit Growers' Convention, Official Report. p. 98-111. Nov. 1895. 114 Eighteenth Fruit Growers' Convention, Official Report. p. 36, 37. 1894. Also: California State Board of Horticulture, Fifth Biennial Report 1895-96:67.

115 Eighteenth Fruit Growers' Convention, Official Report. p. 46. November, 1894.

116 Pacific Rural Press 49:116. 1895. California Fruit Growers 16(8):144. 1895. The latter report is the more detailed. Each gives the list of representatives at the organization meeting held in San Francisco on February 18. See also: Weinstock, H. Review of the work of the California Fruit Growers' and Shippers' Association. Nineteenth Fruit Growers' Convention, Official Report. p. 10-11. November, 1895. 
of achieving the things mentioned in the respective resolutions of the Fruit Growers' Convention in November, 1894. It was formed without capital stock, and was not entrusted with the function of carrying out selling transactions.

The management of the Bureau of Information, which the California Fruit Growers' and Shippers' Association was expected to operate, was placed in the hands of the secretary of the organization. In regard to this feature of the set-up, the by-laws said:

It shall be his [the secretary's] duty to issue and mail daily to each member of the association who for such service shall pay in advance one dollar per month, a printed bulletin setting forth without giving names of consignees or consignors the number of cars and approximate contents that have been forwarded that day to the various markets, and also a statement of such diversions as have been reported. The proposed bulletin shall also set forth in a tabulated form the cars and their approximate contents due and to arrive in the various markets on the various days.

In other words, the Association's set-up provided for the operation of what is today commonly called a clearing house, and became the first clearing house in the California fresh-deciduous-fruit industry. ${ }^{117}$

The cost of running the California Fruit Growers' and Shippers' Association was to be met mainly by collecting a membership fee of $\$ 20$ and charging the members a certain rate in proportion to their shipments. Any fruit grower, fruit-shipping firm or corporation, or member of a cooperative fruit marketing association was allowed to join the enterprise upon approval of the Board of Directors.

Most of the large shipping firms, cooperative associations, and several large growers joined the organization. The National Fruit Association, one of the large shipping firms, refused to join. The first Board of Directors consisted of N. R. Salsbury, of Porter Bros.; E. T. Earl, of the Earl Fruit Company; J. Z. Anderson, of the Anderson Fruit Company; Frank H. Buck, of Vacaville; J. D. Mathews, of the Newcastle Cooperative Fruit Company ; H. B. Stabler, of the Sutter County Fruit Growers' Association; and Harris Weinstock, of the Orange Vale Colonization Company. ${ }^{118}$ Weinstock was elected President. IIe also became General Manager of the organization. The first Executive Committee was composed of N. R. Salsbury, E. T. Earl, and Harris Weinstock. In other words, the two leading dealer firms constituted a majority of the com-

117 A clearing-house type of organization known as the Western Cantaloupe Exchange has been mentioned as the first clearing house of this sort. It was set up in Los Angeles in the spring of 1912 by the leading cantaloupe interests of the Imperial Valley. See Commercial Bulletin (Los Angeles) vol. 28, May 10, May 31, and July 26, 1912. The California Fruit Growers' and Shippers' Association, however, preceded the cantaloupe organization by some seventeen years.

118 California Fruit Grower 16(8):145. 1895. 
mittee. In response to a complaint that the organization was run by the Earl Fruit Company and Porter Bros., two more members were added to the Board of Director's and to the Executive Committee, these to be fruit growers. 'The men selected were David Reese, of the Florin Fruit Growers' Association, and A. Block, a fruit grower and shipper in Santa Clara County who had been prominent in the affairs of the old Union.

Among the cooperative associations which joined the combination were: Cooperative Fruit Company of Newcastle, Suisun Valley Fruit Union, Florin Fruit Growers' Association, Sutter County Fruit Growers' Association, Califormia Fruit Association of Vacaville, Auburn Cooperative Fruit Company, Niles Fruit Growers' Association, Mount Shasta Fruit Association, and Santa Cruz Mountain Fruit Exchange. ${ }^{119}$

Work of the Combination.-The Association immediately endeavored to correct the evils of the auction system. In cases in which several auction houses had developed in eastern markets it sought to consolidate them. Furthermore, it began to attack the closed auction system. These efforts lasted through 1895 and 1896 and brought some favorable results. ${ }^{120}$ In some instances, however, it proved to be very difficult to reconcile the different interests.

The Association also promptly established a Bureau of Information or clearing house which was operated as long as the Association existed. Its activities consisted mainly in compiling and distributing a bulletin during the shipping season, giving data on the number of cars shipped and their destination, which enabled shippers to better regulate their shipments. ${ }^{121}$

119 California Fruit Grower 16(8):144. 1895. Pacific Rural Press 49:116. 1895. It is not entirely clear from reports available that all of these organizations actually took out memberships but representatives of them are mentioned as having joined.

120 At any rate the single auction system was established in New York and successfully operated during the season of 1897. Reported by Manager Weinstock at the Fruit Grower's' Convention, November, 1897. (Pacific Rural Press 54:342. 1897.) At the close of the next season he reported that the association "has succeeded in maintaining union auction houses free and open to all buyers in all the auction markets." (Pacific Rural Press 56:381. 1898.) Later reports are less definite on this point.

121 This "Bureau of Information" was apparently established early in the shipping season of 1895 . Weinstock mentions it in his report in November of that year as one of the Association's accomplishments, referring to it as having been "of incalculable value largely in preventing unnecessary gluts and enabling grower's and shippers to more intelligently route their fruit than was ever before possible."

There was some criticism of it on the grounds that it hid some information by grouping some shipments under the heading of "other points." Weinstock explained that it had been necessary to so group reports on shipments to small markets as not to disclose the business of certain operators, otherwise these refused to let the railroads report their shipments. Nineteenth Fruit Growers' Convention, Proceedings. p. 39-40. November, 1895. 
The activities of the Association apparently did not go beyond the efforts to do away with the abuses of the auction system and the gathering and dissemination of market information. There is no evidence that the Association ever sold fruit. In his reports to the Fruit Growers' Conventions, Weinstock never indicated that the Association had fostered the establishment of local associations. That it would do this was a vain hope of the directors of the California Fruit Exchange.

Although the report of President Weinstock before the Twenty-sixtl Fruit Growers' Convention in December, 1901, spoke of the past year as "one of the most favorable years in the history of the California fruit industry," 122 it was decided at the annual meeting in June, 1902, to discontinue operations.

\section{CONTINUED EFFORTS TO ESTABLISH A CENTRAL COOPERATIVE AGENCY}

Since the leaders of the movement for a comprehensive grower-owned and grower-controlled cooperative marketing system, based on the exchange plan, considered the California Fruit Growers' and Shippers' Association only an organization created to bring temporary relief, they endeavored to carry out those promotional activities among the deciduous-fruit growers which they had urged at the Fruit Growers' Convention in November, 1894, and later. Furthermore, they called a convention of fruit exchanges for the purpose of discussing the establishment of the proposed organization, the California Fruit Exchange. At this convention, which was held in January, 1895, representatives of driedfruit exchanges, cooperative fresh-deciduous-fruit shipping associations, and otler fruit interests were represented. ${ }^{123}$

So far as the fresh-fruit branch is concerned, a special committee was appointed to consider the question of what, on the basis of the known facts, the desired State Exchange would be able to do for the deciduousfruit growers in the near future. This committee proposed the adoption of the following resolutions and recommendations:

Resolved, That it is the sense of this convention that the California Fruit Exchange, as it will be hereafter constituted, can profitably serve the fresh-fruit trade in the following particulars:

1. It can watch over the promised expediting of fresh-fruit service as promised by the railroads, and by frequent consultation with the railroad officials ascertain and make known the degree of perfection or imperfection maintained, and whatever 1901.

122 'Twenty-sixth Fruit Growers' Convention, Official Report. p. 16. December:

123 Pacific Rural Press 49:52. 1895. 
can be done either by the railroads or the growers to improve the efficiency of the service.

2. It can cause accurate official experiments to be made under disinterested inspection of new devices for refrigeration and other devices for packing and shipping.

3. It can, if proper eastern representation can be secured, obtain accurate official reports upon existing eastern abuses in the fresh-fruit trade, with names and dates of instances in sufficient detail to ensure correct knowledge of usual and average conditions, with the remedies, if any, which can be applied, by united action.

4. It can represent that interest in any formal consultations which may be necessary or wise, with those engaged in the business of shipping fresh fruits, with the view of remedying any abuses which may be found to exist in that department.

5. It can obtain and make known the prospects of crops in all competing freshfruit districts, with the dates upon which their products may be likely to appear in the markets in competition with our own-the last to be wired to us in season to permit all to exercise judgment in forwarding.

6. That all fresh-fruit cooperative organizations who pack and sell as growers, and all persons engaged in the same business, and sellers of fruit grown by such persons, shall become eligible to all privileges to which dried-fruit cooperative companies have by becoming stockholders of the State Fruit Exchange, and shall pay the same percentage on gross sales of said green fruit.

All the above being preparatory and looking to effective, remedial action whenever sufficient reliable data have been accumulated to justify such action.

The manager of the Exchange is requested officially to communicate with the Executive Board of the Southern California Fruit Exchanges, and ascertain whether it would be agreeable to them for the State Exchange to unite with them in the support of an eastern agency, upon the basis that they pay the salary and direct the agency from December to June and the State Exchange from June to December; and if so, what would be the expense to this Exchange.

The Committee on the Fresh Fruit Trade is requested to ascertain what number of fresh-fruit shipping associations or individuals are willing to join the Exchange for the above objects, with the probable value of shipments from each, and to report whether in their judgment the revenue from such associations on the same ratio that dried-fruit associations pay is likely to be equal to the expenditure incurred in the fresh-fruit interests. 124

The report was adopted by the convention, and at first it seemed as though the movement would go ahead quickly. Instead, it died during the year 1895, the main reason probably being lack of support on the part of the growers. At the Fruit Growers' Convention of November, 1895, there was an insistent urge that efforts to develop local associations be continued. The following resolutions were adopted after much discussion : $:^{125}$

124 Pacific Rural Press 49:52. 1895.

125 Nineteenth Fruit Growers' Convention, Official Report. p. 98-111. November, 1895. 
RESOLVED, That this convention urgently recommend the formation of local cooperative fruit-growers' unions in every one or more school districts in the State, wherever there are any fruit interests. The purpose of these unions being to consider the subject of cooperation, and to undertake only such and so many plans of cooperation as are made possible by the local conditions, availing themselves of such counsel and assistance as may be obtained from the California Fruit Exchange, with the purpose of securing State unity of action through district, county, and State delegate conventions;

RESOLVED, That to forward this movement a committee of five be appointed, who shall prepare such explanatory literature as may be necessary to the beginning of the movement;

RESOLVED, That the State Board of Horticulture be requested to print and distribute such literature as may be prepared by this committee to such persons in the various parts of the State as they may consider likely to aid the movement;

RESOLVED, That we, as members of this convention, pledge ourselves to do all in our power to sceure such organization in our respective localities.

In accordance with the resolution, a committee of five was appointed consisting of R. D. Stephens, B. F. Walton, A. R. Sprague, C. J. Berry, and F. M. Righter. ${ }^{126}$ The committee reported at the next Fruit Growers' Convention held in December, $1896 .{ }^{12 \tau}$ The report pointed out that there was an indisposition on the part of some growers to act together and an utter inability on the part of many others who were financially obligated to commission men. The committee therefore recommended against the formation of any state association, but expressed the belief that much good might come through local cooperation and urged its development.

However, the idea of cooperative organization of the fruit growers remained and another movement started in 1897. This movement had exactly the same aims as the preceding one. R. D. Stephens, a grower and shipper, was its main leader. He not only stressed the evils of consignment and the burden of high refrigerator car charges, but he also criticized the work of the California Fruit Growers' and Shippers' Association which, he said, did not achieve the improvements predicted at the time of its organization. When Stephens pleaded for local and state organization at the Fruit Growers' Convention in November, 1897, he was opposed by Weinstock who expressed the opinion that it was impracticable to build up a state-wide growers' organization for fresh deciduous fruits. However, Stephens succeeded in having the convention pass a resolution urging growers in the various localities to organize for the marketing of their fruit, and to band together in a state-wide organization. ${ }^{128}$

126 Nineteentlı Fruit Growers' Convention, Official Report. p. 111. November, 1895.

127 Pacific Rural Press 52:372. 1896.

128 Pacific Rural Press 54:338. 1897. 
Very little progress was made in central and northern California during 1898, but the movement was more successful in the southern part of the state. There the growers of fresh and dried deciduous fruits established the Southern California Deciduous Fruit Exchange. It was created in May, 1898, and became the general agent of a number of local associations handling fresh deciduous fruits, dried fruits, and walnuts. ${ }^{129}$ So far as its selling operations are concerned, it made an agreement with the Southern California Fruit Exchange-the citrus fruit organization - to use the salaried eastern sales force of the latter. ${ }^{130}$

The Fruit Growers' Convention held in November, 1898, recommended a continuation of the efforts toward collective marketing, particularly among the dried-fruit growers. ${ }^{131}$ The movement to organize the fresh-deciduous-fruit growers was given new impetus at a meeting of fruit growers held at Sacramento, May 23, 1899. In connection with the complaints of unsatisfactory marketing conditions for fresh and dried fruits, a good deal was said against the excessive refrigerator car charges which were thought to be due to the existence of a refrigerator car combine. ${ }^{132}$ The growers resolved "that we advise the immediate organization of a Fruit Growers' Association of Northern California. The purpose of this organization shall be to establish a car line or any other method of securing transportation relief and facilitate the profitable marketing of our fresh and dried deciduous fruits." 133

The task of carrying out this decision was placed in charge of a committee of which R. D. Stephens was the chairman. ${ }^{134}$ The committee came to the conclusion that the best thing would be to have the prospective organization own and operate a car line itself. It worked throughout the summer and autumn of the year in the Sacramento and San Joaquin valleys and in other fruit sections of central and northern

129 Pacific Rural Press 55:342. 1898.

130 Pacific Rural Press 55:407. 1898.

131 For resolutions passed at this meeting see: Pacific Rural Press 56:378. 1898. These were proposed by A. R. Sprague, Manager of the Southern California Deciduous Fruit Exchange, who urged the formation of local exchanges which in turn should join a central exchange. He urged all [dried] fruit interests to consolidate.

132 Pacific Rural Press 57:322. 1899. San Francisco Chronicle 69(129):1-2. May 24,1899 . The call for the meeting of May 23, 1899 "is the culmination of the aggressive movement inaugurated by the San Francisco Chronicle some weeks ago when the existence of an alleged combine of refrigerator car line interests became evident." California Fruit Grower 24(20):2. 1899.

133 Twenty-fourth Fruit Growers' Convention, Official Report. p. 19. 1899. California Fruit Grower 24(21):3. 1899.

134 The other members of this committee were IV. R. Fountain, W. E. Lovdal, F. C. Niles, E. I. Galvin, and F. A. Chadbourne. California Fruit Grower 24(21):3. 1899 . 
California seeking to get the growers behind this plan. ${ }^{135}$ It was, however, not able to gain the support of a sufficiently large number of growers which would have justified the immediate establishment of the proposed Fruit Growers' Association of Northern California. ${ }^{136}$ The kinds of obstacles the committee members had to face in their organization work were well outlined in the committee's report to the next Fruit Growers' Convention in December, 1899. These obstacles are worthy of note because, to a large extent, they had hindered the progress of organization in California over and over again. The pertinent part of the committee's report reads as follows:

The committee did all in its power to bring about an organiaztion of the fruit growers of the State as outlined by the convention, but has failed so far to accomplish the desired result. It found that it was antagonized by men representing millions of dollars, whose interests are diametrically opposed to those of the grower. The failure to perfect an organization of the growers may be attributed to the following: Apathy, jealousy, intimidation, dissensions, crop mortgages, concessions, and selfishness. Apathy on the part of some who permitted others to think for them. Jealousy on the part of others who fear that their neighbors may be more benefited through the organization than themselves. Dissension among growers caused by difference of opinion as to how to proceed in organizing and upon what plan. Intimidation controls the action of many who are given to understand that any action on their part to in any way aid the movement being made to organize might result in materially impairing their personal interests. Crop mortgages prevent independent action on the part of the mortgagees. Concessions made to growers in the way of rebate on commissions, so much per package, or in any way that would be satisfactory to the parties interested. Selfishness on the part of many who desire to sell to one or the other of the great commission and shipping organizations, the opportunity for which was offered through the agitation being made in favor of organizing the growers for the purpose of marketing their products. Such men would say, "You are all right, go ahead; we are with you, but we have a lot of fruit we wish to sell f.o.b., and are now negotiating to that end. When we have sold we will be with you heart and soul, and do all we can to aid in building up an organization that will better protect their interests than has been done in the past. In the meantime, however, do not for the world abandon the effort to bring about a perfect and complete organization of the State."137

135 California Fruit Grower 24(22):11. 1899. San Francisco Chronicle 69(129): 1-2, May 24, 1899; 69(137):6, June 1, 1899; 69(138):3, June 2, 1899. Pacific Rural Press 57:322. 1899 .

136 An interesting feature of this proposed organization was the "pooling" of the stock and placing it in the hands of a board of trustees who should have the right to vote it during the next five years. California Fruit Grower 24(25):1. 1899. San Francisco Chronicle 69(153):16. June 18, 1899.

137 'Twenty-fourth Annual Fruit Growers' Convention, Proceedings. p. 20. 1899. 


\section{THE CALIFORNIA FRUIT EXCHANGE}

'The need for a fresh-fruit marketing association was again discussed at the Fruit Growers' Convention held at Fresno in December, 1900. A committee of fifteen was appointed with M. Theodore Kearney as chairman, to consider the feasibility of cooperation between all the fruit interests of the state. This committee recommended the formation of an association for fresh-deciduous-fruit producers and proceeded to call a convention for that purpose. ${ }^{138}$ In his call for the meeting which was to be held at Sacramento on January 15, 1901, Kearney" ${ }^{139}$ said, "The problems presented to the fruit growers are two: (1) How to lay upon the consumer's table fruit perfect in quality and at the lowest cost consistent with a reasonable profit to the producer and others whose services are necessary to the industry ; 2 ) how best to develop a demand for our fruits in the markets of the world."

About half of the delegates attending the meeting at Sacramento were from Placer County. The rest were from Fresno, Sutter, Butte, Sacramento, Yuba, Yolo, San Joaquin, and El Dorado counties. ${ }^{140}$

The convention soon appointed a committee on organization which reported back to the convention after about an hour's deliberation. ${ }^{141} \mathrm{It}$ recommended the formation of an organization of fresh-fruit growers, under the Cooperative Marketing Act of 1895, along the lines of the California Raisin Growers' Association and the California Cured Fruit Association. ${ }^{142}$ The adoption of a plan similar to the raisin plan is not surprising since M. Theodore Kearney, Chairman of the committee was then president of the Raisin Growers' Association. He, no doubt, influenced the group to some extent, although on the other hand, the California Raisin Growers' Association was at that time considered highly successful. ${ }^{143}$

138 For a list of the other members of this committee and a copy of its recommendations see: California Fruit Grower 25(655):3. 1900. The matter of bringing all the fruit and nut interests together into some sort of fruit producers' council was not developed. See: Pacific Rural Press 61:89. 1901.

139 California Fruit Grower 26(659):12. 1901.

$140 \mathrm{~A}$ list of men in attendance is given in: Record-Union (Sacramento) 100 (148):2. Jan. 16, 1901. A preliminary meeting had been held in San Francisco on Jan. 8. California Fruit Grower 26(659):4. 1901.

141 See copy of its report: Record-Union (Sacramento) 100(149):2. Jan. 17, 1901.

142 The latter had been modeled after the Raisin Association so that the two were almost identical. Twenty-fourth Fruit Growers' Convention, Official Report. p. 142-3. December, 1899. The articles of incorporation and by-laws of the California Cured Fruit Association are reproduced in full in this issue.

143 It had been formed in the summer of 1898. Mr. Kearney was generally given a good deal of credit for its establishment. The Association discontinued in the summer of 1903 . 
The organization committee recommended a list of names of men to serve as directors during the first year. The committee's recommendations were adopted, and the temporary board proceeded at once to organize. ${ }^{144}$ It elected E. I. Galvin as president, T. W. Madeley as secretary-treasurer, and designated as an executive committee E. I. Galvin, G. H. Cutter, and T. W. Madeley.

Although the original plan of organization was that of a centralized or direct-membership type of association, A. R. Sprague and A. H. Naftzger strongly urged the adoption of a federated type of organization. ${ }^{145}$ The former had been organizer, and was still president and manager of the Southern California Deciduous Fruit Exchange (see page 39 ), and the latter was president and general manager of the Southern California Fruit Exchange. Both associations were of the federated type, and both had attained a considerable measure of success. The federated plan was finally adopted.

As far as other features of the plan are concerned, it was proposed to establish the state-wide cooperative marketing association under the name of California Fresh Fruit Exchange, ${ }^{146}$ and to incorporate it under the Cooperative Law of 1895. It was suggested that the organization should be formed on a nonstock basis with a membership fee of $\$ 5.00 .^{147}$ The headquarters were to be in Sacramento.

From the explanations given by various leaders on different occasions before and shortly after the establishment of the Exchange, it seems that the following were substantially the aims $:^{148}$

1. To sell the fruit of its members.

2. To eliminate or minimize the consignment of fruit.

144 Record-Union (Sacramento) 100(149):2. January 17, 1901. The temporary board of directors consisted of: B. F. Langford, San Joaquin; Wm. Johnson, Sacramento; E. I. Galvin, Sacramento; F. A. Chadbourne, Solano; H. W. Meek, Alameda; A. D. Cutts, Sutter; J. F. Madden, Placer; J. W. Anderson, Yolo; T. W. Madeley, Placer; I. N. Barton, Placer; S. L. Turner, El Dorado; O. B. Olufs, Fresno; A. R. Sprague, Los Angeles; and Geo. H. Cutter, Sacramento.

145 Sprague, A. R. Work of the California Fresh Fruit Exchange. Twenty-sixth Fruit Growers' Convention, Official Report, p. 51-52. 1901.

140 The name "California Fruit Exchange" was suggested, but the dried-fruit organization which had been operating under that name some years earlier had apparently not yet been dissolved, hence its name could not be used. On May 26, 1903, the Exchange reincorporated under the above name. Mr. Sprague explained that it was easier to reincorporate under the new name than to go through the necessary court procedure to drop the word "Fresh" from the old name. The new organization then bought the assets of the old. Pacific Rural Press 65:406. 1903.

147 Record-Union (Sacramento) 100(149):2. January 17, 1901.

148 For more detailed information see: Kearney, M. Theodore. Pacific Rural Press 61:84. 1901. And: Sprague, A. R. Work of the California Fresh Fruit Exchange. Twenty-sixth Fruit Growers' Convention Proceedings. p. 54-55. 1901. 
3. To eliminate faulty distribution which alternately gluts some markets and leaves others bare.

4. To promote grading of all fruit in accordance with a high standard, and to market only the best quality.

5. To adopt and maintain a high standard of packing.

6. To establish associations operating local packing houses in localities where a need developed, and to have the fruit graded and packed under a local inspector's direction in the case of isolated orchards.

7. To let each district have a separate and distinct accounting with the central headquarters for all fruit sold, and to make returns thereon on the basis of actual sales for that district and not on a general average of the season's sales for all districts.

8. To assist growers in working out their financial problems so as to free them from the commission firms which advanced them money and so prevented them from joining a cooperative.

9. To lower the costs of supplies of boxes, lumber, paper, and other materials by joint purchasing.

Membership.-At the time the Exchange was established, practically all local associations which had been formed in the preceding twenty years had disappeared. It was, therefore, necessary to establish new local units and to affiliate them with the Exchange. In view of this need, one of the principal jobs of the executive committee of the Exchange at the start was to go into the field and organize local groups. It got in touch with the important shipping points in central California, such as Loomis, Newcastle, Penryn, Placerville, Rumsey, Colfax, Florin, Fair Oaks, Vacaville, Marysville, Lodi, Yuba City, Chico, Walnut Grove, and Courtland. But, in spite of strenuous efforts, the executive committee was able to establish locals during the first season only at Loomis, Newcastle, Penryn, Rumsey, and Placerville. ${ }^{149}$ It found one in existence at Florin, but was not able to bring it into the Exchange at once.

Being desirous of increasing the volume of business as quickly as possible in order to perform the business at low marketing costs, the Exchange endeavored to spread rapidly from the shipping points where its first local associations had been formed. In some instances the new units that it set up succeeded, but in other instances they failed. Thus the agencies established in Colfax and Placerville were given up after a two years' trial, and the agency at Visalia was withdrawn after the experience of one season. When such retrenchments occurred, the organization sustained several severe financial losses.

149 Sprague, A. R. Work of the California Fresh Fruit Exchange. Twenty-sixth Fruit Growers' Convention Proceedings. p. 52. 1901. 
After the experience of the first few years, the policy of quick expansion was given up. Instead, the Exchange has preferred to follow the plan of expanding only in accordance with the spread of the cooperative spirit among the growers. ${ }^{150}$ In 1909, the number of local associations affiliated with the Exchange was fourteen. ${ }^{151}$ It also had at that time followed the practice of establishing "agencies at points at which there were no associations." These agencies were discontinued as soon as a local association was formed and affiliated with the Exchange. ${ }^{152}$ By 1926 the number of local associations amounted to 63 , and in 1931 to 80 . In addition to 80 local associations, approximately 100 so-called "contract shippers" were connected with the Exchange in 1931. These contract shippers are members who not only pack and ship their own fruit, but who in some cases also handle the fruit of other growers. The total approximate number of growers marketing their products through the Exchange was 1,700 in 1916, 4,500 in 1922, and 7,500 in 1931. Out of 7,500 growers shipping through the Exchange in 1931, approximately 7,000 were members of local associations. The remaining 500 or so were either contract shippers or were shipping through contract shippers.

During the first few years, the Exchange was active mostly in central California, particularly between Fresno on the south and Winters and Auburn on the north. By 1909 it had contacts at practically every important shipping point in the central part of the state with the exception of the apple districts centering at Sebastopol and Watsonville. Later, it spread its activities over most of the state including the Gravenstein apple section in Sonoma County, and has also expanded into Arizona.

Organization Activities. - The Exchange has promoted in various ways the establishment of new local associations. It has helped interested

150 The general manager stated in his report for 1924 that: ". . . it is unwise to encourage the formation of associations unless growers have sufficient confidence in cooperative marketing to lend their support to the movement .... the organization of cooperative associations should be discouraged in any community where the loyalty of the members to themselves and their confidence in the organization are not manifest." California Fruit Exchange, Annual Report 1924:15. 1924.

151 These included: Acampo Fruit Growers' Association; Acampo Christian Colony, through J. P. Dargitz; Auburn Fruit Growers' Association; Courtland Fruit Growers' Company; Florin Fruit Growers' Association; Fresno Fruit Growers' Company; Linden Fruit Growers' Association; Loomis Fruit Growers' Association; Lodi Packing Company; Newcastle Fruit Growers' Association; Penryn Fruit Growers' Association; Sacramento River Association; Vacaville Fruit Growers' Association; Winters Fruit Grower's' Association. In addition the Exchange had marketing arrangements with the San Joaquin Table Grape Growers' Association for members who desired to ship through it. See: Walker, W. C. A grower's' marketing organization. Thirty-sixth Fruit Growers' Convention Proceedings. p. 104. December, 1909.

152 Walker, W. C. A growers' marketing organization. Thirty-sixth Fruit Growers' Convention Proceedings. p. 104. December, 1909. 
local groups in developing a wider interest in certain communities by supplying speakers to explain the operation of the Exchange and by discussing the experiences of other local associations. It has assisted the growers in drawing up by-laws and developing plans of operation. In some cases it has advanced money to new associations for the erection of packing houses and has extended credit for supplies. It has also made it a practice to advise with the locals on management problems, especially during their early stages, or when new managers are employed. The Exchange has brought about a certain amount of uniformity in the structure of local associations by recommending certain types of by-laws and even drafting suggested standard by-laws.

In order to set up new local associations and to keep in contact with the growers, field agents were employed as early as 1903, 1905, and 1908. During recent years much of the field work of the Exchange has been carried on at the seven district offices which are located at Lodi, Modesto, Fresno, Exeter, Ontario, Winters, and San Jose. From these offices the agents and their assistants endeavor to promote the relations of the Exchange with the various local associations and contract shippers, and to win over new followers among the unorganized growers.

Throughout its history the Exchange has done much in the way of educating the growers in cooperative marketing. ${ }^{153}$ To promote educational work, the Exchange in March, 1924, began the publication of a house organ, the Blue Anchor. This publication is not only circulated among members, but it also reaches the various groups of the fruit trade, state and federal agricultural officials, farm advisors, as well as university and high school libraries.

Functions of the Local Associations.-The main functions of the local associations are grading, packing, assembling, and loading the fruit. In the early days practically all the packing was done in the orchards from which the packed boxes were hauled to the loading sheds. Some

153 In his report for 1928, the general manager, Mr. Nagle, stated: "There is, I regret to admit, too great a proportion of our membership who are not sufficiently impressed with the principles of cooperation to permit of any relaxation in our effort to carry on this educational work." (California Fruit Exchange, Annual Report 1928:16. 1928.)

In regard to the magazine he said: "The Blue Anchor Magazine, which is published monthly by our standardization department and distributed to our growers and members of the trade, not only in this country but in foreign countries as well, has succeeded beyond all expectations. It is recognized by federal and state authorities as the best magazine on deciduous fruits published today. Its circulation includes nearly all the countries of the globe, and approximately 100,000 copies are distributed annually. The magazine is practically self-sustaining, and could be made so if we were to encourage more advertising than now appears within its covers, but we feel that too large a proportion of advertising would detract from the value of the reading matter and defeat the original purpose of the publication." (California Fruit Exchange, Annual Report 1928:10. 1928.) 
exceptions occurred in Fresno, Acampo, and Lodi where the fruit was hauled to the shipping houses in lug boxes to be packed and loaded. The practice of orchard packing led to the use of grower brands and prevented the development of pooling because the individual packs varied too widely. Since 1923, however, more and more fruit is packed in central packing houses. This change has come because of the necessity of improving and standardizing grade and pack in order to meet the increasing competition of fruit produced not only in California but also in other parts of the United States. The change has come largely as a result of the educational effort of the Standardization Department of the Exchange.

The district offices mentioned above (page 45) have not developed sales functions as is true in the California Fruit Growers' Exchange. ${ }^{154}$ Such a development has, however, been given consideration. The general manager in his report for 1927 said :

We believe that within the next few years associations in different districts will band themselves together for the purpose of forming sub-exchanges to work with the main exchange and operate as a link between the associations and the general office. I believe that such a condition is justified and will materialize because within the next five years our business will automatically double and such a change will become necessary. 155

Apparently, in 1927, it was thought that the number of small associations would so increase as to make such subexchanges desirable. No such development has taken place, and the management now feels that the present plan of having each local deal directly with the central organization makes for speed in operation-a matter of vital importance in the fresh-deciduous-fruit business.

Representation.-As long as the number of local associations was small each association was represented on the board of directors. As the number of local associations became larger this plan became less satisfactory. Hence, in 1910, the Exchange adopted the plan of providing for associate directors. It was provided that each growers' organization having a shipping contract with the Exchange and not being represented on the Board of Directors, should be entitled to select from its membership some one to sit with the Board at all its sessions. The associate directors were to enjoy all the privileges of the regular directors with the exception of the vote. After some time, however, this system was dropped, but any member is welcome to sit in the board of directors' meetings as a visitor.

154 McKay, A. W., and W. McKenzie Stevens. Organization and development of a cooperative citrus-fruit marketing agency. U. S. Dept. of Agr. Dept. Bul. 1237: 23-5. 1924.

155 California Fruit Exchange, Annual Report 1927:15. 1927. 
During the early years of the Exchange directors were nominated from the floor at the annual meeting. It came to be recognized that this plan did not permit adequate consideration of the most desirable geographical distribution of the directorate. In order to have the directors more fairly represent the growers, the state was divided into zones in 1924. These zones were established by a special committee after a careful consideration of the tonnage, gross value, geographical grouping, and accessibility to headquarters. ${ }^{156}$ Eight zones were established and the seventeen directors allocated to these districts. In $1931^{157}$ the number of districts was increased to nine. There have been one or two directors at large-two in 1932, one from the south and one from the west of the state.

The directors are nominated in the several districts at meetings called for the purpose some time before the annual meeting of the Exchange. When several directors are to be elected from a given district-some districts have from 3 to 4 -a district may further allocate these to subdistricts. The names of the men nominated in the several districts are then reported to the chairman of the nomination committee of the Board of Directors. These names are placed in nomination at the annual meeting and elected by acclamation. There is nothing to prevent individuals from making other nominations from the floor at the annual meeting. Such nominees would probably stand little chance of election because the members believe the present plan insures fairness in representation.

A. R. Sprague, the former president of the Southern California Deciduous Fruit Exchange, was the first president and also the first general manager of the California Fruit Exchange. Some opposition to the practice of having one man hold both these offices arose. In 1910 the by-laws were amended to prevent this.

In 1907 Mr. Sprague resigned and G. H. Cutter, formerly vice-president, was made president. At the same time W. C. Walker, who had been the eastern agent of the Exchange, was appointed general manager. In 1910 Walker was succeeded by the present manager, J. L. Nagle, then manager of the Newcastle Fruit Growers' Association. When G. H. Cutter died in 1926, J. J. Brennan was elected president. There has been very little change in the Board of Directors of the organization-a good indication of stability in the association and confidence on the part of the growers in their leaders.

Sales Methods and Problems.-When the Exchange was organized in 1901, President A. H. Naftzger of the Southern California Fruit Ex-

156 Pursuant to a resolution of the board of directors on November 18, 1924, a committee consisting of C. S. Day, R. J. Coggeshall, Freeman B. Mills, and B. E. Knapp was appointed to work out the matter of districting.

157 Letters of instruction sent out December 20, 1928, and December 3, 1931. 
change offered the services of the eastern sales staff of his organization which consisted of over 20 salaried agents and numerous brokerage connections in the principal cities. The California Fresh Fruit Exchange (now called the California Fruit Exchange) accepted the offer. The contract provided that the agents should handle fruit coming from only the two organizations and that, so far as the fresh-fruit business was concerned, they should receive instructions directly from the Sacramento office. $^{158}$

By making use of this selling machinery the new Exchange immediately had a large number of eastern agents at its disposal. Although these agents had not handled fresh fruit before, they were familiar with the handling of California fruit, since the buyers of citrus fruits were also buyers of deciduous fruits. This joint sales arrangement has continued throughout the history of the Exchange with the exception of the two marketing seasons of 1903 and 1904 when the Southern California Fruit Growers' Exchange sold through the California Fruit Agency, and the California Fruit Exchange joined the California Fruit Distributors.

The system of salaried agents has evidently worked to the benefit of both organizations. So far as the California Fruit Exchange is concerned, the general manager praised the plan in his report for 1928 . He said :

Our eastern agents have voluntarily in many instances taken advantage of market conditions by raising our prices before delivering the car. The increase in prices thus brought to our growers will run into thousands of dollars. This fact alone is a sound argument in patronizing an organization that has a selling agency of salaried men instead of a corps of brokers who are frequently buyers' and not sellers' representatives. I might add in this connection that the success of the California Fruit Exchange is due largely to the fact that we are privileged to maintain an agency of salaried men whose integrity has been tested, whose ability is unquestioned, and whose successes are measured by the long years of efficient service they have rendered this institution. 159

158 It is interesting to trace the history of the plan to use joint agencies in the East for the selling of deciduous and citrus fruit. The idea seems to have originated in the north in 1885, when the California Fruit Union was organized. It will be remembered that at that time $\mathrm{H}$. Livermore, one of the leaders of the California Fruit Union, went to Los Angeles and advised the southern citrus fruit growers to join the California Fruit Union and to take advantage of the eastern selling machinery which the Union intended to create. (See page 18.) The idea of using common sales agents in the East was favored; but, because the citrus-fruit growers thought it advisable to organize separately, the plan was not then realized. It was discussed for the second time in 1894, again following a suggestion from the north, in connection with the movement to organize a state-wide marketing organization for dried and fresh fruit. In this case the idea was not carried out because the northern plan of organization did not materialize. It, therefore, took another period of six years before the system of joint agencies for the selling of deciduous and citrus fruit was put into effect.

150 Annual report of the General Manager for 1928, p. 5-6. 1928. 
Any opposition to joint selling that has arisen has come inainly from certain groups of Valencia orange growers affiliated with the California Fruit Growers' Exchange. One reason for taking up the plan originally was that citrus fruits moved in greatest volume during the winter and spring when there were no deciduous-fruit shipments. Later, however, the development of a large volume of summer shipments of Valencia oranges brought up the question of whether the deciduous-fruit business did not interfere with the sales of summer oranges. The matter finally led to a careful study of the problem which seems to have satisfied those who objected. ${ }^{160}$

In 1910, the Exchange began the practice of offering premiums to its eastern agents in order to increase their efficiency. This policy has worked satisfactorily and has been continued. The number of salaried agents in the United States and Canada was about 80 in 1931. Some of these agents are serving only the California Fruit Exchange because the Exchange has thought it advisable to appoint representatives in markets with which the common agents do not stand in direct contact. The number of common agents amounts to about 50 .

As already stated (page 43), during its early years the Exchange endeavored to increase the volume of its business as quickly as possible. It was therefore eager to handle not only more and more fresh fruit, but also undertook the handling of dried fruits and vegetables. In 1903, it made arrangements for the marketing of dried fruits in the Santa Clara Valley; about the same time it made arrangements for the handling of celery for the Jersey Island Packing Company in Contra Costa County. The handling of celery in the winter time was considered to be a welcome means of supplementing the summer-fruit business. In the same year, the Exchange also made arrangements for the marketing of melons for growers in Tulare County. It soon withdrew from the dried-fruit business as well as from the handling of vegetables, and in later years it has been much more conservative not only in taking up new lines of products, but also in expanding its business in the sphere of fresh fruit.

This change in the attitude of the Exchange was characterized by Mr. Cutter in his address at the annual meeting in January, 1911. At that time Mr. Cutter pointed out:

You would think the more business we get the better for the Exchange. We used to think so, but it cost us lots of anxiety. For people who have never shipped, everything is new. The pack is new, the business is new. They start in with the thought that the mere affiliation with us is a guarantee that they are going to get a price whether

160 Gardner, K. B. Joint use of a sales organization by two cooperative associations. U. S. Dept. of Agr. Cir. 10:1-31. 1927. 
the price is warranted or not. If their pack is not up to grade it works a hardship on them and on the Exchange. If their pack is second class and is put up against your pack, which you have been ten years in perfecting, you can see how it affects your own. If we were to take on too much of that class of business, you can see how it would weaken the Exchange.161

In recent years the Exchange has handled only such fresh fruits as grapes, apricots, cherries, figs, nectarines, peaches, pears, plums, apples, pomegranates, and persimmons.

The Exchange uses mainly two methods of sale-public auction and private sale. It endeavors to market the fruit in the way the growershipper or local association manager desires to have it sold. If he wishes to have it offered at auction, the Exchange does so. ${ }^{162}$ Many growers have preferred to confine their sales to a few of the large auctions, although recently there is a greater willingness among the members of the Exchange to have their fruit distributed over a wider area ${ }^{163}$ and to leave the distribution more largely to the management. The management itself has of late expressed in the following words a desire to increase the authority of the Sales Department and has urged upon shippers the practice of permitting sales without instructions from shippers.

I wish to impress upon our shippers one point, namely, the advisability of permitting the Sales Department to make sales without instructions from the shipper. It is not possible for the average grower, contract shipper, or association manager to have sufficient knowledge from day to day of market conditions throughout this country and elsewhere to enable him to place restrictions on his cars, both as to price and to movement, with the same accuracy of judgment as would be used by our Sales Managers. After reviewing statistics compiled in this office annually, I am convinced that if this Sales Department were unhampered in its judgment of choice of markets and diversions, better results in many instances could be obtained for the shipper. It is the duty of our Sales Department to keep our shippers advised daily as to market conditions, but our Sales Department should be given a free rein by our shippers in carrying out the obligations of their office, and I hope that during this coming year our growers and association managers will see to it that their cars carry unlimited privileges so far as our Sales Department is concerned. If it becomes necessary at any time during the season for cars to be stored, our Sales Department should not be required to obtain the consent of the shippers before such action is taken. Prompt action is oftentimes imperative in order to save our growers from sales losses, and our Sales Department should be unhampered in the exercise of its judgment.164

161 California Fruit Exchange, Annual Report 1911. (unpublished.)

162 The General Manager said: "Privilege of selling at auction is always accorded a shipper, and the Exchange does not attempt to dictate the markets to which cars are shipped. The Sales Department welcomes suggestions as to methods of sale preferred by shipper." California Fruit Exchange, Annual Report 1916. (Unpublished.)

163 California Fruit Exchange, Annual Report 1929:6. 1929.

164 California Fruit Exchange, Annual Report 1930:7. 1930. 
In his report for 1927, the General Manager raised the question of eventual acquisition of auctions and other selling facilities in the terminal markets. He said:

The advisability of increasing our scope of operations to include selling facilities such as the ownership of auctions in certain markets, has been before our directors for some time. Whether this is practical or not at present has not been definitely decided, but it has been urged that certain cooperatives coordinate their interests for the purpose of maintaining their own auctions. This is a much mooted question, and the answer may be some years away, but whether it be in my time or in yours, the time will come when the fruit producers of California, both citrus and deciduous, will control the marketing of the products of this state, and when this condition develops, the producers will be obliged to maintain their own auctions. 165

\section{TABLE 1}

Percentages of Auction and Private Sales by the California

Fruit Exchange, 1924-1931

\begin{tabular}{|c|c|c|c|}
\hline Season & Number of cars & Auction sales & Private sales \\
\hline 1924 & 8,485 & $\begin{array}{c}\text { per cent } \\
54\end{array}$ & $\begin{array}{c}\text { per cent } \\
46\end{array}$ \\
\hline $1925 \ldots \ldots \ldots$ & 11,934 & 60 & 40 \\
\hline $1926 \ldots \ldots \ldots \ldots$ & 12,092 & 59 & 41 \\
\hline $1927 \ldots \ldots .$. & 12,226 & 57 & 43 \\
\hline $1928 \ldots \ldots$. & 13,629 & 65 & 35 \\
\hline $1929 \ldots \ldots$ & 10,505 & 63 & 37 \\
\hline $1930 \ldots \ldots \ldots$ & 15,237 & 64 & 36 \\
\hline $1931 \ldots \ldots \ldots$ & 10,607 & 59 & 41 \\
\hline
\end{tabular}

Source of data:

Compiled from Annual Reports of California Fruit Exchange.

So far, the Exchange has not acquired the ownership of any auction market, nor has it undertaken any joint measures in this direction with other cooperatives.

From the beginning, the method of selling at auction has played an important role. In recent years the percentage sold at auction has varied from 57 per cent to 65 per cent. (See table 1.)

Pooling.-The practice of pooling spread slowly among the local associations. The Loomis Fruit Growers' Association was one of the first units to pool its members' fruit. It decided at the beginning of 1923 to pool the fruit of its members by size and variety in weekly periods. The following year a number of other member associations began to pool their fruit. 
The increase in the practice of pooling was largely brought about by the criticism of the "drug store car" 166 by the trade, and the advocacy by Exchange officials of "long lines"-i.e. larger lots of uniform size and variety.

With the adoption of measures for standardization, and the establishment of community packing houses, pooling practices spread rapidly. By 1927 approximately 75 per cent of the tree fruit moved through the Exchange and was pooled under first- and second-grade labels. ${ }^{167}$ One year later, F. W. Read, ${ }^{168}$ head of the Standardization Department of the Exchange, made the following statement:

We have eliminated the individual grower's name, and... are pooling in most of the tree-fruit associations and in some of our grape associations by size and by grade and variety, over a definite period of time. Our pools in the deciduous-fruit fields are usually daily pools. Sometimes they are car pools, but rarely are they longer than a daily pool. The reason for this is that with us the market fluctuates very rapidly. It changes from day to day and from week to week, and the grower who produces early fruit is not very prone to pool his fruit with another grower who produces a late fruit, even of the same variety.

Advertising.-The Exchange has carefully and gradually developed the advertising of its fruit. Before entering into a wide advertising campaign it created definite standards of quality and devoted considerable time to the education of its growers and the trade.

The organization has developed several trade-marks of its own, the principal one of which is the Blue Anchor brand. This brand was proposed by G. H. Cutter in 1903, and was used from that time to 1924 without any special restrictions for designating the fruit shipped by the California Fruit Exchange. In 1924 it was chosen as a trade-mark for the fruit of superior quality with the result that it now enjoys a high reputation.

The Calex brand was introduced in 1928 for juice grapes grading U. S. No. 1 or better. In 1929 the Exchange began to use a special Blue Anchor label for its export shipments. This label promises to replace, in many cases, the labels of the export firms which used to put their own labels on their shipments. By doing so the Exchange hopes to gain for itself part of the advertising value of labels, which formerly went to

166 The term "drug store cars," is applied to cars containing many small lots of fruit of similar size and variety, but of varying pack and maturity packed by individual growers. In an endeavor to meet the demand of the eastern trade, the leaders of the Exchange urged the members of the associations to pool the fruit of even sizes, grade, and maturity wherever possible and recommended community packing houses to aid in accomplishing this objective.

167 California Fruit Exchange, Annual Report 1927:8. 1927.

168 Read, F. W. Field work of the California Fruit Exchange. American Cooperation, 1928. 1:415. 1928. 
the exporters, and thus to contribute to the development of its export business.

At the end of 1930, the management believed that the development of its brands had reached a point where an intensive advertising campaign might be undertaken in the East for the next season. It was therefore decided to launch an advertising campaign in certain eastern markets in 1931. The plan provided for a complete advertising program utilizing the following media: (1) newspapers, (2) trade papers, (3) outdoor billboards, (4) radio, (5) chain store advertising, and (6) dealer service. This campaign was restricted to the New England states in 1931 because it was looked upon as an experiment and because it was felt that the value of advertising deciduous fruits could better be tested if the limited funds were spent in a restricted area than if they were spread over the entire country. ${ }^{169}$ In 1932 the same territory was covered in much the same way except that dealer service was extended somewhat, particularly into the maritime provinces of Canada, to take advantage of publicity obtained through radio broadcasts which extended into those areas.

Volume of Business Handled.-During the period of more than thirty years in which the Exchange has been active, its shipments have increased steadily. Only 201 cars were shipped in 1901, while 15,237 cars were sent out of California in 1930. (See table 2.) The greatest absolute increase occurred in the decade from 1921 to 1930. During this time, the number of cars shipped by the Exchange increased from 6,281 to 15,237. The decrease in Exchange shipments in the 1931 season was caused by poor crop and market conditions. The percentage of total cars shipped from the state by the Exchange was greater in 1931 than 1930. These shipments cover all produce handled by the Exchange. Among them grapes rank first, as shown in table 2. Next in importance are pears, peaches, and plums.

The Exchange has not only increased its shipments, but has also been successful in expanding the area over which its fruit is distributed. Whereas the 201 cars shipped in 1901 were sold in only 38 markets of the United States and Canada, the fruit shipped in 1930 was sold in approximately 500 carload markets.

The Exchange has likewise increased its sales abroad. Describing the development of exports in his report for 1929, the General Manager said :

Ten years ago the California Fruit Exchange, realizing that the ever-increasing production of fruits in the United States would eventually tax to eapacity the domestic markets, especially during the peak movement of these products, made a

169 California Fruit Exchange, Annual Report 1930:9. 1930. 


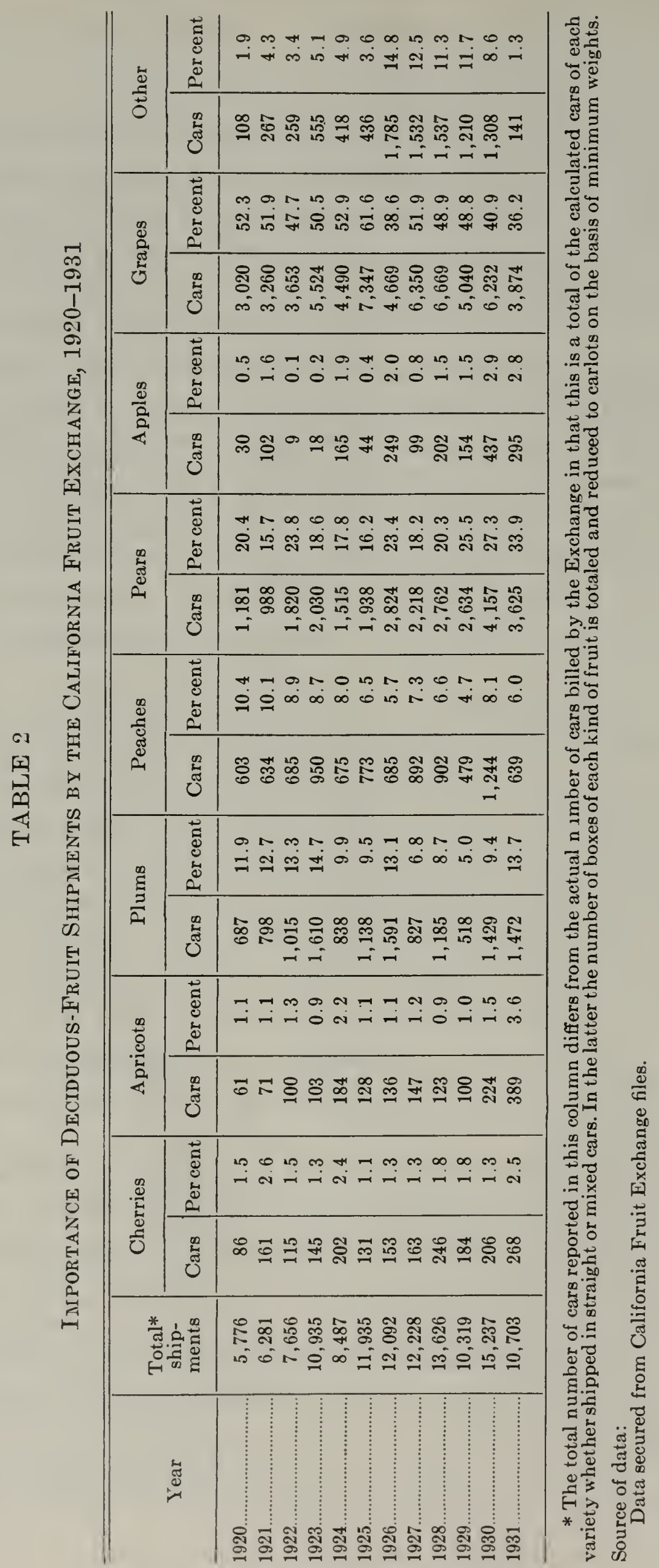


survey of foreign markets with a view to developing its export business, which at that time was almost negligible. During the intervening years, the Exchange has quietly but persistently extended its efforts in this direction until, in 1929, it enjoyed the fruits of those years of pioneering in this field, and it is a pleasure to report that our export business for this past year amounted to over $\$ 1,500,000$, or approximately 10 per cent of the total gross sales of the season. This is a very remarkable showing and offers encouragement for further work in this field.

It is interesting to note that our fruits have been shipped to practically every corner of the globe. In Europe we have made substantial shipments to Denmark, England, and Scotland; in South America, to Brazil and Argentine on the West Coast; and also to Central America and the Canal Zone. Transpacific shipments have gone to the Hawaiian and Philippine Islands, China, Japan, Java, the Straits Settlements, and New Zealand. Pears represented the heaviest tonnage of any one variety, while apples were second, and grapes third. A number of straight cars of plums were shipped and also a few ears of peaches. The first ear of cherries ever exported to South America was shipped by the California Fruit Exchange this past season, with satisfactory results, the fruit having carried exceptionally well and having met with favor from the trade.

With the arrangements recently completed for representation in the Orient and new connections made in Europe, we have every reason to believe that within a few years we shall be successful in establishing our brands throughout the world and disposing of a very liberal proportion of our tonnage outside of the United States.170

The above was written at the close of the last year of a period of prosperity. Expansion of the export business has continued even during the current depression. In 1931 the Exchange exported 1,018 cars exclusive of Canadian sales, with gross sales value of $\$ 2,053,414$. $^{171}$

The Exchange has endeavored to develop an export pack which corresponds to the demand of the foreign markets. That it has been successful in doing this, is indicated by the increased shipments abroad. All the shipments to Great Britain, the Orient, and Continental Europe are made on a cash California basis.

Supply Business.-The Exchange engaged in buying operations for its members right from the start. At first a wide variety of supplies were purchased, even certain classes of staple groceries, but it soon found that these purchasing operations were tying up a large amount of its capital, and since a number of losses occurred, it became more conservative in later years. Its purchases are now confined to supplies which are essential in growing and shipping fruit.

In 1930 the Supply Department handled 1,507 cars of shook and bracing material, 30 cars of baskets, 71 cars of paper and paper products, 20 cars of nails, 81 cars of kegs, 66 cars of grape packing, and a large

170 California Fruit Exchange, Annual Report. 1929:6-7. 1929.

171 California Fruit Exchange, Annual Report 1931:7. 1931. 
amount of spray material. Table 3 gives the volume of business and the gains each year since 1921.

The organization claimed at the beginning that it often sold the supplies at much lower prices than those prevailing in the open market. Later it adopted a policy of selling at about prevailing prices and included any savings in its rebates. On box shook, however, the policy since 1921 has been to charge the associations and contract shippers prices which left practically no margin, but on other material it has aimed to make about 5 per cent.

TABLE 3

Comparative Statement of Supply Departarent, 1921 To 1931 INCLUSIVE

\begin{tabular}{|c|c|c|}
\hline Year & Supplies furnished & Net gains on supplies \\
\hline 1921. & $\$ 1,105,316.51$ & $\$ 15,290.38$ \\
\hline 1922. & $1,496,766.62$ & $51,921.20$ \\
\hline $1923 \ldots$ & $2,096,449.56$ & $67,624.22$ \\
\hline $1924 \ldots \ldots . .$. & $1,764,939.62$ & $66,504.91$ \\
\hline $1925 \ldots$. & $2,149,007.77$ & $34,898.15$ \\
\hline $1926 \ldots$ & $2,116,658.18$ & $36,672.53$ \\
\hline $1927 \ldots \ldots \ldots$ & $1,864,327.11$ & $46,919.85$ \\
\hline $1928 \ldots \ldots \ldots \ldots$ & $2,133,413.88$ & $43,264.75$ \\
\hline $1929 \ldots \ldots \ldots . . .$. & $1,766,478.01$ & $31,334.76$ \\
\hline $1930 \ldots \ldots \ldots \ldots$ & $2,369,122.09$ & $53,535.80$ \\
\hline $1931 \ldots \ldots \ldots \ldots$ & $\$ 1,687,742.78$ & $\$ 39,959.90$ \\
\hline
\end{tabular}

The purchasing activities have not only benefited growers financially, but have also contributed to the development of a more uniform type of supplies. The department has constantly shown a net gain at the end of each marketing season. (See table 3.)

In spite of the advantages offered by these purchasing operations to the members, the Exchange has had some difficulty in inducing all the associations and contract shippers to buy their supplies through the Supply Department. The Exchange-local contract provides that the local may purchase supplies elsewhere if they can be obtained at lower prices than the Exchange can quote.

Lumber Department.-Tn October, 1919, the Exchange took an important step when it established its own source for shook material and boxes by purchasing a sawmill, a box factory, and 15,000 acres of timber in Plumas and Sierra counties. The immediate purpose of this enterprise, in which the Exchange invested about $\$ 1,300,000$, was to protect its members against increased prices of shook material which threatened to come at that time on account of the post-war boom in building con- 
struction. There were also, however, more fundamental reasons for this step, namely, the desire to save for the fruit growers any profits arising from the box business, and more particularly to place the Exchange in a stronger bargaining position in dealing with the box manufacturers for the purchase of a portion of its requirements.

The Exchange does not use all the timber which it cuts; it has so far used only about 50 per cent of it for the manufacture of boxes. The remainder, consisting of higher or lower grades than are ordinarily used for boxes, has been sold in the open market. The Lumber Department has furnished about 25 per cent of the shook material requirements of the Supply Department. In 1930, the operations of the box factory were increased to the point where at least 33 per cent of the required shook is manufactured within the organization.

In the first five years the Lumber Department realized high earnings. The subsequent depression in the lumber market decreased its earnings. Nevertheless, a surplus was made even in the very unfavorable year 1930. In addition to the timber bought in 1919, the Exchange has purchased options on timber in neighboring districts which will enable it to fill its requirements for the next forty or fifty years.

Standardization Department.-The need for standardization was early recognized among the members of the Exchange, but little progress was made during the first few years. Some of the members participated in a movement for the standardization of fresh fruit around 1912. This general movement led to the drafting of a bill for standardization in 1914, and to the enactment in 1915 of the first Standardization Act for California fruit. However, progress was too slow to suit the Exchange officials who recognized the importance of meeting increased eastern competition with quality. The Board of Directors in 1923 decided to set up a special department to carry on this work among its members. ${ }^{172}$

In 1925 the Board decided that the Blue Anchor brand should be used only on first-quality fruit shipped by the Exchange and that its use should be restricted to those associations or contract shipper's who were willing to abide by the special rules laid down by the Standardization Department. ${ }^{173}$ At the same time it was thought advisable also to establish an eastern inspection service for the Blue Anchor brand and other brands handled by the association. Such inspection was to be carried out under the immediate supervision of the Exchange.

The Standardization Department has established standards, regulated the use of brands, recommended and assisted in the establishment

$17^{2}$ California Fruit Exchange, Annual Report 1922:2. 1922. (Mimeo.)

1;3 California Fruit Exchange, Annual Report 1925:7. 1925. 
of community packing houses and the perfection of grading equipment. It has endeavored to do away with the multitude of brands, and has encouraged the adoption of pooling by local associations. This work has been made possible through the cooperation of local boards of directors and packing-house managers. The Blue Anchor standards are maintained by a group of trained inspectors who operate under the direction of the head of the Standardization Department and who are on the payroll of the central Exchange.

During the past several years the Standardization Department has not confined its work to questions of standardization. It has also given consideration to legislative matters of interest to the Exchange or its members, and more recently has given advice to the growers regarding their future planting. The General Manager in his report for 1930 stated:

Despite the fact that this Standardization Department was created for the purpose of enabling the Exchange to encourage growers in the better packing and grading of their fruits, the increase in membership in the Exchange, together with the increased volume of business, has necessitated the enlargement of the scope of the work originally allotted to the department. We now find the department actually a field consultation department, carrying its work also into the formation of new associations.

A complete survey has been made throughout the state on a statistical basis, which now enables the Standardization Department to intelligently recommend or discourage the planting of certain varieties of fruits in certain sections. ${ }^{174}$

Traffic Department.-This department of the Exchange takes care of all matters which have to do with the transportation of fruit. It files and handles railroad claims, deals with general transportation problems, and handles diversions, the supply of refrigerator cars, and other related matters. According to the 1930 report of the General Manager, the total claims collected by this department from the railroads during the last ten years have amounted to more than $\$ 1,500,000$. The services of this department have doubtless also led to increased care on the part of the carriers in the handling of the fruit.

Insurance Department.-The matter of insurance was first given consideration in the Exchange in 1919. At that time, a plan was proposed for the establishment of a mutual insurance system for the packing houses associated with the Exchange. However, nothing was done at that time to carry out this proposal. The question was again raised in 1921, but no decisive action was taken until 1929, and the Insurance Department was not established until 1930. ${ }^{175}$ The Insurance Department handles both fire and compensation insurance.

174 California Fruit Exehange, Annual Report 1930:9. 1930.

175 Blue Anchor 8(7):19. 1931. 
Marketing Contract.-The contract between the Exchange and the local associations is of the agency type. The contract used for some years prior to 1932 said:

The party of the first part [the local] hereby appoints the said Exchange as its sole marketing and selling agent for all deciduous fruits under its control (except such fruit as shall be sold for cannery purposes and ripe fruit), for which the Exchange shall deduct from the growers' account sales seven (7) per cent of the gross receipts, in full compensation for such service, including eastern brokerage, non-local telegrams and telephones and all other expenses incurred by the Exchange in doing so.

A new contract, adopted at the beginning of the 1932 crop season, though still of the agency type, contains distinctly different and somewhat novel wording. Paragraph 2 reads :

Exchange shall have the exclusive right to market all of said deciduous fruits and grapes and first party [the local] shall deliver possession of the same to said Exchange for that purpose.

In drawing up the new contract an attempt was made to specify more simply and definitely the obligations of the two parties. The legal procedure arising out of a misunderstanding with one of the local associations brought out the fact that the old contract was vague on a number of points. One of these points was on the interpretation of the exemption in regard to "ripe fruit." Hence the new contract omits reference to ripe fruits in the paragraph quoted above but covers it in a later paragraph by excepting from the contract fruit too mature to permit shipment under refrigeration to points over 100 miles distant from first parties' loading station.

Another point at issue in the above-mentioned case was the right of the Exchange to withhold the local associations' share of the various patronage dividends. The new contract therefore states that "Said commissions shall be the sole property of the Exchange, it being agreed that its marketing of said fruits and grapes represents a full and complete consideration for said commissions."

The new contract specifies definitely that the local "shall be entitled to patronage dividends ("withholdings repayable')" only on condition that it "fully and faithfully complies with all of the obligations."

The contract is automatically renewed from year to year unless canceled by either party by written notification on or before December 31 of any year. The value of the annual withdrawal privilege was questioned by the manager in his report for 1927. He said: "Owing to the fact that in recent years growers have been inclined to treat their agreement lightly, it has been my thought that it might be well to consider 
lengthening the period of the contract from one to three years." ${ }^{176}$ The new contract, however, has continued to use the year-to-year self-renewing feature.

Financing.-Soon after the Exchange was organized it was found that its need of capital was much larger than anticipated. It was often necessary to make advances in order to hold members and in some cases even to release growers from their obligations to independent fruit companies. ${ }^{177}$ Additional money was required to help local associations build loading and packing sheds and to carry on educational work. While the organization was able to borrow money from the banks, the latter were not willing to lend money on notes of the Exchange alone. They frequently required the directors, personally, to endorse such notes.

The Exchange found itself faced with a large debt by 1907 chiefly because of the losses sustained in connection with the policy of rapid expansion which was followed at the outset. In order to remedy the situation, the banks proposed that the Exchange give up its nonstock character and reincorporate as a capital stock association. This proposal was carried into effect at the beginning of $1907 .{ }^{178}$ The new organization had an authorized capital of $\$ 100,000$, divided into equal shares of $\$ 100$ each. In order to eliminate the danger of control by a few persons, no individual or organization was allowed to hold more than 10 shares. In 1918, this limitation was reduced to $5,{ }^{179}$ and when new by-laws were adopted in 1920 the number was further reduced to 2 shares. ${ }^{180}$ By 1912 , capital stock amounting to $\$ 40,100$ had been issued. At the end of 1930 , the amount of outstanding stock was $\$ 81,200$. It was early advocated that each local association should purchase a share of capital stock. Many local associations have followed this suggestion, so that today practically all of them own 1 or 2 shares.

So far as dividends on capital stock are concerned, it was provided in 1907 that, first, a dividend of 6 per cent should be paid out of the net earnings of the Exchange, and, secondly, that after 20 per cent of the net earnings was credited to a reserve, one-half of the remainder should

176 California Fruit Exchange, Annual Report 1927:17. 1927.

177 "To a larger extent than was counted upon, we found the grower tied up with loans from fruit companies, so that they were not free to take their business where their inclination led." From the 1907 report of A. R. Sprague, General Manager of the Fruit Exchange. See also: Sprague, A. R. Work of California Fruit Exchange. Twenty-sixth Fruit Growers' Convention, Proceedings. p. 55. 1901.

178 The reorganization meeting was held February 19, 1907. Walker, W. C. A growers' marketing agency. Thirty-sixth Fruit Growers' Convention, Official Report. p. 102.1909.

179 Annual meeting of the California Fruit Exchange, January 18, 1918.

180 Minutes, adjourned meeting of Board of Directors of the California Fruit Exchange, March 25, 1920. p. 363. 
be paid to the growers as an additional dividend on stock, the other half to be distributed in the form of a patronage dividend. This arrangement resulted in very high dividends on stock in 1907 and 1908. In the latter year the dividend was $321 / 2$ per cent. Because some considered it undesirable for a cooperative organization to pay such high dividends on capital stock it was provided early in 1909 that one-fourth instead of one-lialf of the above remainder should be distributed as an additional dividend on capital stock, and the other three-quarters of the remainder distributed as a patronage dividend. ${ }^{181}$ In 1910 dividend provisions were again changed. ${ }^{182}$ After payment of a regular dividend of 10 per cent on paid-up stock, and adding to the reserve fund 10 per cent of the net earnings, all the remainder was to be paid as a patronage dividend. In 1922, in order to comply with the provisions of the CapperVolstead Act, the regular dividend was further reduced to 8 per cent.

There was little opportunity to create a reserve prior to 1907 . The value of a strong reserve was, however, recognized very early. When the Exchange was reorganized in 1907, provisions were made for quickly developing a substantial reserve. From 1907 to 1909, 20 per cent of the net surplus was set aside; from 1910 to 1911, 10 per cent; and from 1912 to 1916, 15 per cent. As a result of this policy, the Exchange had acquired a reserve by 1917 equal to nearly one and a half times the amount of the paid-up capital. ${ }^{183}$

The accumulation of so large a reserve led to a change in the financing system in 1917. A committee consisting of J. J. Brennan, F. B. Mills, J. L. Nagle, and G. H. Cutter was appointed to work out a new plan. This committee recommended: First, the establishing of an operating fund; secondly, the placing of this operating fund on a revolving basis; and thirdly, the refunding to growers at once of portions of their contributions to the reserve which had been built up since 1907.

The plan submitted by the committee was adopted at the stockholders' meeting of the Exchange held on January 8, 1918. It was also decided at that meeting that the first refund of contributions to the reserve should be made immediately, covering the amounts withlheld during the years 1907 to 1911. The newly created operating fund which is called a "Withholdings Repayable" fund was to receive first, any saving from the 7 per cent charge made by the Exchange on all fruit handled; secondly, the amount accrued in excess of the cost of supplies handled; and

181 Amendment to Article XIX of by-laws adopted at annual meeting of the California Fruit Exchange, January 12, 1909.

182 Amendment to Article XIX of by-laws adopted at annual meeting of the California Fruit Exchange, January 11, 1910.

183 Nagle, J. I. Fiftieth Fruit Growers' Convention, Official Report. p. 12. 1917. 
thirdly, the sums flowing to the Exchange from any other sources. The Withholdings Fund reached its maximum in 1929 when (December 31) it stood at $\$ 1,870,276.72$.

The possession of such a large operating fund has placed the Exchange in position to reach out for increased business both on the shipping side and on the supply side. Moreover, it has placed it in position to borrow large sums at commercial banks on unsecured corporation notes.

Table 4 gives the yearly status of this "Withholdings Repayable," or revolving fund, from its beginning. The payments from amounts in the fund have varied from year to year. Likewise there are accounting adjustments from year to year in some of the items. It will be noticed that with the decline in the volume of business in 1931 the additions to the fund fell off. This situation was aggravated in 1932. In order to meet the new problem the Exchange in 1931 modified its plan by setting up a reserve of one-half of one per cent of its gross sales. ${ }^{184}$ This is presumably to supply a more permanent reserve than is furnished by the revolving fund.

It has repeatedly been suggested, especially since 1925, that the Exchange return to the status of a nonstock association. The motive behind this movement was probably the desire to make the Exchange a membership association and to bring the organization more in legal accord with the cooperative practices which have been developed in the Exchange in spite of the existence of certain privileges of the stockholders under the law. No steps have been taken to effect the proposed change.

When the Exchange was reorganized into a stock association in 1907, the change was made primarily because the banks asked for it. They wanted to shift the burden of their loans and to obtain greater security. So far as this reason is concerned, it has lost its importance since the capital stock of $\$ 80,000$ actually issued is negligible when compared with the size of the operating fund accumulated by the Exchange and its annual business ranging between $\$ 14,000,000$ and $\$ 19,000,000$ in recent years.

Patronage Dividends. - The system of distributing patronage dividends has been described on page 60 . These patronage dividends were at first paid in one sum at the end of the marketing season. From 1912 to 1917, the Exchange followed the policy of distributing the dividends in two parts, the first payment being made on January 1 ; the second payment on August 1 of each year. The principle of this method of distri-

184 The Exchange actually had sufficient contracts at the beginning of the 193] season to give it a volume of 20,000 cars. Because of crop and business conditions only 10,864 were shipped. California Fruit Exchange, Annual Report 1931:21. 1931. 


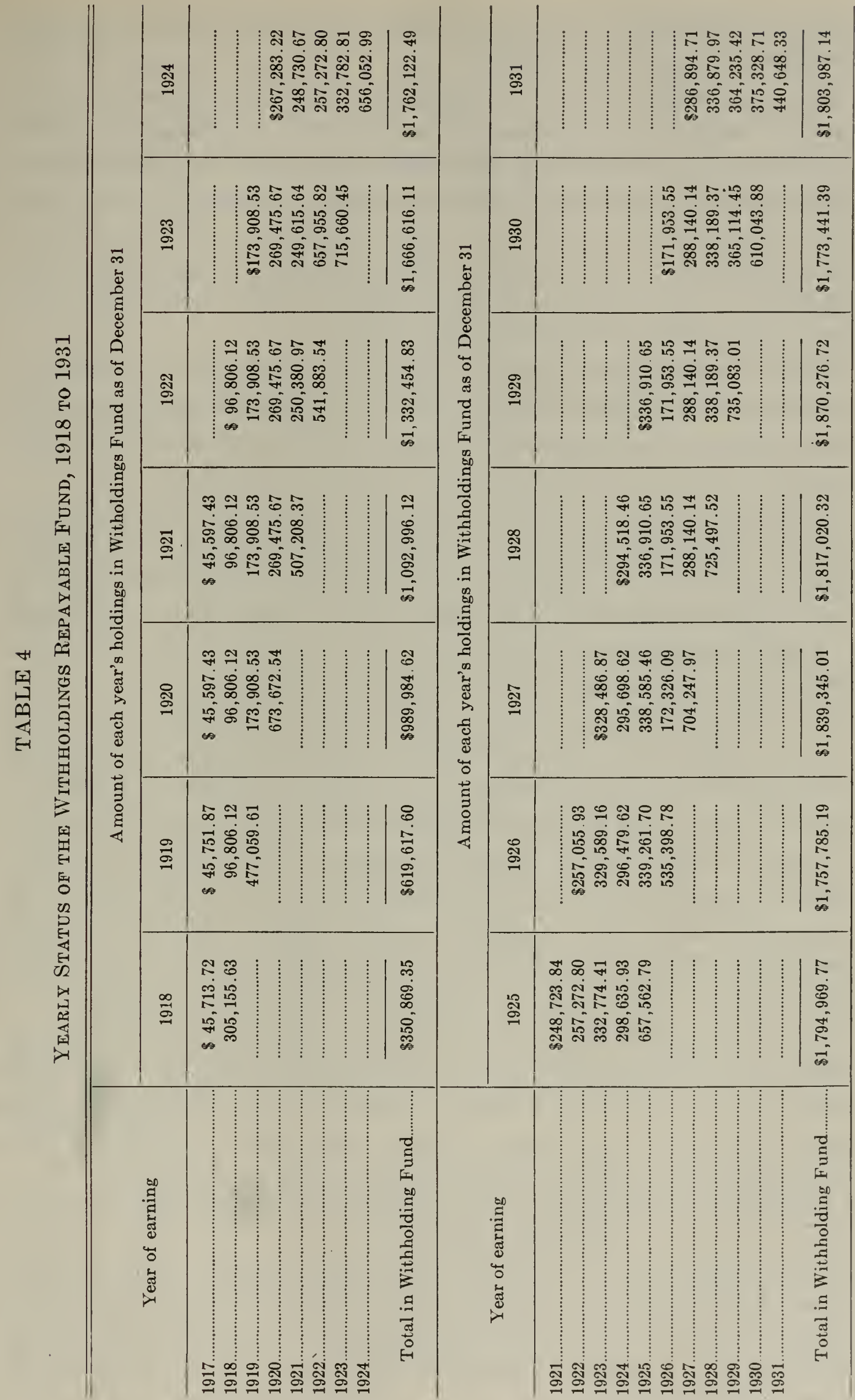


bution was later taken over into the system of the operating fund, though the times of payment have varied.

In making refunds from receipts of a given year, the following method has been employed in late years. The income from trading operations, and other sources (other than commission on selling) is subtracted from the expenses of operation. ${ }^{185}$ The remainder, spoken of as "net cost of operation," is subtracted from the gross income obtained from the selling commission of 7 per cent. Out of the remainder the patronage dividends have been declared. Between 1920 and 1931 these have varied from 3 per cent to 5 per cent of gross sales.

It has been suggested that the charge of 7 per cent of sales be decreased. One of the main reasons for not acting on the suggestion is that by charging the prevailing commercial rate the grower is more easily shown how much he has saved by cooperative marketing. ${ }^{186}$

The Exchange has to meet an extensive demand for credit from its local and contract shippers. It is asked to make advances for the financing of production, harvesting, and purchasing of supplies, the establishment of marketing facilities and many other things. The advances made by the Exchange have frequently reached very high figures. ${ }^{187}$ Sometimes large amounts had to be carried over to the next year.

The advances are secured by the withholdings of the Exchange in the operating fund. They are paid back by means of deductions made from the fruit sold through the Exchange and in some cases they enable the members to get their necessary supplies without any outside borrowing.

After the fruit is sold, returns are made by the Exchange, usually within twenty-five days. No individual grower accounts are kept by the Exchange except with contract shippers. This is done by the local associations. Returns are made by the Exchange in bulk to the several associations and distributed by the latter to the grower members.

The Exchange has had a good influence on the financial policies of its local units. It has advised them to create reserve funds as a precaution against hard times and as a means of gaining a good standing with local banks. Following its recommendations, many local associations have

185 By-laws of the California Fruit Exchange, Article XIX, p. 12. 1933.

186 Haight, L. S. Organization and operation of the California Fruit Exchange. Ainerican Cooperation, 1928. 1:194. 1928.

18 in his annual report for 1929, the General Manager pointed out: "It becomes necessary during the peak movement of our fruits to advance to our associations and members throughout the state various sums aggregating approximately three million dollars. These advanees are made only when they are surrounded with adequate security. At the end of the present season, we find the carryover from such advanees to be less than \$50,000." California Fruit Exchange, Annual Report 1929:16-17. 1929. 
adopted the revolving fund system of financing themselves through withholdings. In cases where such a withholding fund is in use, the returns received from the Exchange may not be paid back in full immediately, but part may be held over in the local association a certain period of time in order to be used for the financing of its operations, the extension of credit to members, and the establishment of marketing facilities.

It has long been pointed out that the Exchange could substantially increase its membership and volume of business if it were in position to finance growers who now depend upon advances from private firms. The suggestion was made a few years ago that the Exchange establish a finance corporation for this purpose. A plan was actually worked out in 1931 in collaboration with governmental authorities according to which the Federal Farm Board was to supply 60 per cent of the necessary capital and the Exchange 40 per cent. Both sums were expected to be used as a basis for borrowing from the Intermediate Credit Bank. After a careful consideration of the plan, the Exchange came to the conchusion that it was inadvisable to set up such a credit corporation at that time. One reason for its rejection was that the Intermediate Credit Bank required that in case of loans on perishables the accounts be liquidated every year. Another reason was that, in case a deficit occurred, it would have to be met out of the capital impounded by the Exchange.

Results of Exchange Operations.-Starting with no local units to federate, the leaders of the California Fruit Exchange have built up a strong state-wide marketing organization of the exchange, or federated type, which is grower-owned and controlled and unites about 7,500 producers of fresh deciduous fruits. The business experience it has gained over a period of more than thirty years and the sales machinery it has developed in the East and abroad give it a good basis for the further development of its selling operations. The Exchange has built up a substantial supply business which has been of great benefit to its members, particularly by virtue of the strategic position gained in the shook market.

In its endeavor to follow a sound financial policy it has, since 1907, built up a substantial reserve and created an operating fund which has placed the Exchange in a strong financial position.

In addition, the Exchange has fostered the standardization of the fruit of its members through its efficient Standardization Department, has built up a high reputation for its "Blue Anchor" brand, has improved fruit transportation conditions, and recently has extended its services into the field of insurance. 
The organization has shown its willingness to follow recognized cooperative principles. This is evident by the way in which it has limited its interest payments on capital, by the steps taken for the improvement of democratic control, and by its general adherence to the principle of operation on a cost basis. Furthermore, the Exchange has cooperated, both formally and informally, with various agencies seeking to bring about improvements in marketing.

Competitors of the California Fruit Exchange.-Shortly after the Exchange was established, the independent shippers also banded together and formed a marketing organization, the California Fruit Distributors. This organization included substantially the same group of shippers as had the California Fruit Growers' and Shippers' Association. An important reason for the establishment of this agency was the desire on the part of the fruit-shipping companies to lessen the keen competition which had raged among them during the preceding years. Another reason was the need of meeting the competition of the Exchange and preventing it from spreading its influence among their own patrons.

The organization was established in May, 1902, with headquarters at Sacramento. The plan of organization and operation provided that it should be a stock company with shares of only nominal value, and that the members should market all their deciduous fruit suitable for eastern shipments through this common agency. No individual sales were to be made. Instead, the California Fruit Distributors was expected to dispose of the fruit in its own name, either at auction or by f.o.b. sales. Furthermore, the organizers intended to appoint eastern representatives and to take steps to increase the outlets by expanding the existing markets and finding new ones. Although the agency was to take charge of the handling of all the fruit in the East, each member was allowed to arrange for his own inspection at places where the fruit was to be sold at auction.

In order to cover the expenses of the organization, it was decided that $\$ 10$ should be charged for each car plus 5 per cent of the sales receipts for f.o.b. transactions, and 1 per cent of the sales receipts in addition to the auction charges for auction sales.

A considerable number of difficulties manifested themselves when the attempt was made to bring the various independent shipping firms together. Referring to these difficulties, Alden Anderson, the first General Manager of the organization, stated in 1903 :

The formation of the California Fruit Distributors was not an easy matter. Some firms, because of location or superior packing on their part or better carrying quality of their fruit, enjoyed advantages not common to others. Some of them 
believed that if they could keep on with prevailing methods for a short time they could force their competitors out of business and then would have the field entirely to themselves, while all the time they would likely be losing money for all concerned.188

The various firms which joined the California Fruit Distributors during 1902 were: Frank H. Buck Co. ; Porter Bros.; Earl Fruit Co.; George D. Kellogg; Schnabel Bros. Co. ; Producers Fruit Co. ; Pinkham \& MeKevitt; The Alden Anderson Fruit Co. ; Penryn Fruit Co. ; and A. Block Fruit Co. In the next year, the California Fruit Exchange likewise became a member of the distributors but it belonged to this association of dealers for only two marketing seasons.

According to its by-laws the California Fruit Distributors was governed by a board of directors consisting of eleven members and a board of managers comprising five members. ${ }^{189}$ The latter was charged with the task of directing the shipments, deciding on methods of sale, and naming the prices. At the beginning it met weekly. In 1913, it was ruled that the executive committee should meet daily during the shipping season.

Actual operations were carried out by a general manager. Alden Anderson held the managerial position until 1909. F. B. McKevitt was manager until 1913, in which year Chas. E. Virden followed him. For the 1920 and 1921 marketing seasons W. J. Charlesworth acted in this capacity for the distributors, and from 1922 on, Wilmer Sieg.

For a number of years the California Fruit Distributors handled a large amount of fresh fruit. It started out with control of over 80 per cent of shipments made from California. But its influence gradually declined while that of the California Fruit Exchange and the unorganized independent firms increased. By 1917, its control had dropped to below 50 per cent, and by 1927 the organization handled only about 20 per cent of the fresh fruit shipped out of the state. Like the California Fruit Exchange, the California Fruit Distributors maintained its own salaried agents at important points in the eastern markets.

As early as 1910, the California Fruit Distributors decided to carry on an advertising campaign in the eastern markets. It was successful in increasing the number of outlets for carload shipments. Apart from

188 Twenty-ninth Fruit Growers' Convention, Official Report. p. 54. 1903.

189 The members of the first board of directors were: Frank H. Buck, of Frank H. Buck Co.; James S. Watson, of Porter Bros.; W. E. Gerber, of Earl Fruit Co.; Geo. D. Kellogg; A. H. Schnabel, of Schnabel Bros. Co.; H. A. Fairbank, of Producers' Fruit Co.; Alden Anderson, of Alden Anderson Fruit Co. ; Frank B. MeKevitt, of Pinkham \& McKevitt; A. C. Short, of Penryn Fruit Co.; H. E. Butler, of Penryn Fruit Co.; and Wm. F. Pickstone. Frank H. Buck was made President; W. E. Gerber became first Vice-President; A. C. Short, second Vice-President; Alden Anderson, Secretary; and H. A. Fairbank, Treasurer. The first board of managers consisted of A. J. Hechtman, of Porter Bros.; George B. Katzenstein, of Earl Fruit Co.; Frank B. McKevitt; George D. Kellogg; and A. H. Schnabel. 
these services in the field of selling, the agency also helped its members in other ways. It operated a Purchasing Department for the purpose of reducing the cost of supplies needed by its members. Furthermore, in 1913, it set up a Traffic Department for the collection of railroad claims and the better settlement of other matters pertaining to the transportation of the fruit of its members.

After the 1921 marketing season, a number of shippers who had belonged to the organization left the California Fruit Distributors and set up an organization of their own, the California Deciduous Fruit Companies. This group consisted of the following companies : Newcastle Fruit Company, Silva-Bergtholdt Fruit Company, Placer County Mountain Fruit Company, United Fruit Company of California, James Fruit Company, and the Penryn Fruit Company. Being small shippers and mainly interested in the marketing of fruit produced by their own members, these concerns felt that the policy of the large companies in the California Fruit Distributors did not always harmonize with their own interests.

This split caused a decided decrease in the strength of the California Fruit Distributors. In view of its occurrence the California Fruit Exchange henceforth faced two main rival concerns. The former organization discontinued its operations at the end of 1927. The California Deciduous Fruit Companies, which at one time had as many as seven members, consisted of only two agencies during the 1931 marketing season.

The following reasons led to the decline and disappearance of the California Fruit Distributors: (1) Some of the smaller member firms believed that their interests were not adequately considered by the large firms which dominated the organization; (2) it was difficult to convince the many new firms which were entering the shipping business, especially in fresh grapes, of the value of the organization; (3) some of the firms felt that they could get many of the benefits of the organization without joining; (4) the price policy of the California Fruit Distributors was undermined by outsiders; (5) claims were made that members of the organization themselves were cutting prices and selling directly on their own account; and (6) the growth of the California Fruit Exchange. 


\section{LOCAL AND REGIONAL COOPERATIVE DEVELOPMEN'TS}

Local units had been recognized and urged as a desirable foundation for a state-wide cooperative marketing system at least since the movement for the establishment of the California Fruit Union in 1885. Each of the numerous efforts to form state cooperative marketing organizations led to the discussion of marketing problems. Each in turn led to the formation of local associations here and there in the various deciduous-fruit sections. Sometimes these were formed with the expectation that they would be local units in a larger organization. Perhaps even more they were formed to solve local marketing problems.

The California Fruit Union made some efforts to establish local associations and the formation of some of those which were organized in the second half of the eighties should be accredited to its activities. However, these efforts of the Union did not proceed very far partly because of the apathetic attitude of the growers themselves, and partly because in some communities the leading growers were also large shippers and were therefore not interested in creating local associations at places where they were running their own shipping businesses along with their production units.

Up to 1893, the last active year of the California Fruit Union, local associations had been formed in at least a dozen counties including Sacramento, Napa, Santa Clara, Alameda, El Dorado, Solano, Mariposa, Yolo, Shasta, Placer, Sutter, Yuba, and San Diego. ${ }^{190}$ Some of these associations were established on a county basis, others around given shipping centers. Most of these lived only a few seasons, often only a single season. In many cases the first organization was sooner or later followed by a second or even a third enterprise.

The locals were usually formed for the purpose of assembling, packing, and selling the products of their members in the eastern markets as well as in the nearby markets on the Pacific Coast. In some cases, and on part of their business, they used the sales service of the California Fruit Union, and in other cases, they worked independently selling to or through such of the private shipping firms as made satisfactory offers. Some of them took up canning and drying as well as the assembling, packing, and selling of fresh deciduous fruits. Furthermore, a number of them purchased supplies needed for packing either fresh or cured fruits.

190 According to isolated references to the organization and operation of specific associations. See index of the Pacific Rural Press of this period. Many local associations doubtless escaped mention even in the local press. 
With very few exceptions the local fresh-fruit organizations which were formed in the eighties and nineties in northern and central California had passed out of existence by 1900 . The local cooperative movement, therefore, suffered a decided setback. But the coming of the California Fresh Fruit Exchange in 1901 gave new impetus to local group action, and it was partly due to this new impetus, and partly to the continuous organizational and educational work of the Exchange that the local cooperative movement has grown since that time among deciduous-fruit growers.

In the course of this new period, local cooperatives for fresh fruit continued to spring up independently. Some of them joined the Exchange immediately, some later, while others contracted with private marketing organizations for the shipment and sale of their fruit. All in all, however, the number of fresh-fruit locals which stayed outside the Exchange has been small.

It is obviously not practicable to discuss in detail the history of each of the several hundred local associations that have been formed during the past sixty years. It seems worth while, however, in order to indicate the nature of the development, to discuss a few examples in some detail, inchuding a few regional groups.

Florin Fruit Growers' Association.-The Florin Fruit Growers' Association, formed in 1889 and incorporated in April, 1890, is the only local formed in the second half of the eighties which has continued its operations up to the present time. It was organized under the influence of the Florin Grange and perhaps the California Fruit Union, ${ }^{191}$ and was a successor to an earlier cooperative association, the Fruit Growers' Association of Florin, which had been organized as early as $1877 .{ }^{192}$ The Florin Fruit Growers' Association was formed as a nonstock association

191 H. A. Fairbanks, secretary of the California Fruit Union at that time, reports attending an organization meeting and advising with those interested in its formation. He recalls specifically James Totell, who is known to have been at the first meeting. Interview, June, 1932.

192 On May 18, 1889, the Florin Grange called a meeting to discuss the advisability of shipping fruit cooperatively during the coming season. At a meeting of fruit growers held on June 1 the association was formed and the by-laws of the Florin Fruit Growers' Association adopted as a whole. The by-laws are given in full in: Minutes of Board of Directors, p. 3.

The incorporation papers were not filed until April 9, 1890. Records in Court House, Sacramento, California.

No information has been obtained concerning the Fruit Grower's' Association of Florin except that contained in the by-laws as adopted by the new association, and that eontained in the articles of incorporation filed in the Court House, Sacramento, March 13, 1877. The Association had an authorized capitalization of $\$ 10,000$ divided into shares of $\$ 10$ par value. 
with a membership fee of 50 cents. ${ }^{193}$ About 70 members belonged to it during the 1891 marketing season.

The Association shipped grapes primarily, but also handled berries and cherries during its first years of operation. It became affiliated with the California Fruit Union, and, after the Union disappeared, it made Porter Bros. its agent for Chicago, Minneapolis, Omaha, New York, and Boston, and appointed another agent for the Philadelphia market. In 1896, it sent one of its members to Oregon and Washington to handle the strawberry business in that territory, and in 1898 it established a branch house in Sacramento.

Apart from the collection of a membership fee, its early method of financing consisted of a charge of 1 per cent on the sales receipts and an additional charge of $\$ 1.00$ a ton on all fruit. The association paid patronage dividends from the beginning. That it also devoted some attention to the accumulation of a reserve is evident from the following resolution which was adopted at its annual meeting in January, 1895 :

Resolved that all rebates which have usually been divided at the end of the year, and paid to the members in cash shall be divided as usual, but shall be kept by the association, and placed to the credits of eacl individual member in the book kept for that purpose and shall be known as the "Sinking Fund" which said sums shall bear interest at the rate of six per cent per annum and be paid to members at the end of each year. That said profits, rebates, etc., shall accumulate year after year till such time that the Directors of the Association think the Association has funds enough-that when a member severs his, or lier connection with the association then the Directors shall pay to the said member all moneys due him or her less interest for the year in which he leaves, if before the end of the year.194

'The Florin Fruit Growers' Association became affiliated with the California Fruit Growers' and Shippers' Association early in 1895, though nothing is known of the nature of its participations in the clearing house for fresh fruits operated by that organization. In 1903 it became a member of the California Fruit Exchange and has since then shipped its fruit through that organization.

Newcastle Fruit Growers' Association.-One of the typical local associations of the California Fruit Exchange, the Newcastle Fruit Grower's' Association, may be briefly described. This association, it will be remembered, became one of the first members of the Exchange. It was formed in April, 1901, as a result of the early organization work of the first

193 This fee was raised to $\$ 2.50$ in 1890 , to $\$ 10.00$ in 1897 , and is $\$ 25.00$ today. This and other information concerning this association is from the minutes of the Board of Directors. Courtesy of T. W. Venn, secretary.

194 Annual meeting of January, 1895, from the typed Minutes of the secretary of the Board of Directors. 
executive committee of the Exchange. ${ }^{195}$ The organizer's made it a nonstock organization, and this form has been maintained, although proposals were made in 1908, 1913, and 1916 to change the association into a capital stock organization. ${ }^{196}$

\section{TABLE 5}

Growth of Membership and Business of Newcastle Fruit Growers' Association, 1920-1931

\begin{tabular}{|c|c|c|c|c|c|}
\hline Year & $\begin{array}{l}\text { Member- } \\
\text { ship }\end{array}$ & $\begin{array}{c}\text { Carload } \\
\text { shipments of } \\
\text { Association }\end{array}$ & $\begin{array}{c}\text { Total cars } \\
\text { shipped from } \\
\text { Newcastle }\end{array}$ & $\begin{array}{l}\text { Percentages } \\
\text { shipped by } \\
\text { Association }\end{array}$ & $\begin{array}{l}\text { Gross sales } \\
\text { receipts }\end{array}$ \\
\hline $1920 .$. & 74 & 484 & 1,748 & 28 & $\$ 1,005,993$ \\
\hline $1921 \ldots \ldots$. & 86 & 536 & 1,821 & 29 & 945,547 \\
\hline $1922 \ldots \ldots$ & 103 & 606 & 2,042 & 30 & 778,931 \\
\hline $1923 \ldots . .$. & 111 & 865 & 2,547 & 34 & $1,124,001$ \\
\hline $1924 \ldots \ldots$ & 115 & 718 & 1,948 & 37 & $1,089,415$ \\
\hline $1925 \ldots .$. & 120 & 877 & 2,358 & 37 & $1,302,777$ \\
\hline $1926 \ldots \ldots$ & 128 & 949 & 2,712 & 35 & $1,177,765$ \\
\hline $1927 \ldots \ldots$. & 140 & 867 & 1,999 & 43 & $1,390,014$ \\
\hline $1928 \ldots \ldots \ldots \ldots$ & 154 & 1,007 & 2,299 & 44 & $1,366,711$ \\
\hline $1929 \ldots \ldots$ & 135 & 1,218 & 2,030 & 60 & $2,049,710$ \\
\hline $1930 \ldots \ldots \ldots \ldots \ldots \ldots$ & 134 & 1,623 & 2,705 & 60 & $2,021,371$ \\
\hline $1931 \ldots \ldots \ldots \ldots \ldots \ldots$ & 147 & 1,350 & 2,061 & 65 & $\$ 1,735,250^{*}$ \\
\hline
\end{tabular}

\footnotetext{
* Estimate.
}

Source of data:

Minutes of meetings of Board of Directors of Newcastle Fruit Growers' Association.

Despite strong competition from independent shippers, the association has constantly increased its membership and business. In 1901 it had 17 members. In 1911 it served 46 growers and, by 1931, its membership had reached 147. Its shipments in the 1914 season amounted to 333 cars, about 20 per cent of all shipments from Newcastle. In 1931 its shipments comprised 1,350 cars, or 65 per cent of all Newcastle shipments of that year. Table 5 shows the growth of membership and business from 1920 to 1931.

Patronage dividends have been paid from the start to members who

195 The original meeting was held at Newcastle on April 7, 1901. C. H. Kellog acted as chairman and T. J. Madeley acted as secretary. Sprague addressed the meeting.

This was, of course, not the first association in this section. An association of 15 growers was mentioned in the fall of 1885 as having "handled many carloads of fruit." (See: Pacific Rural Press 30:271. 1885.) The news items columns of the Pacific Rural Press and the California Fruit Grower contain numerous references to meetings of local associations at Neweastle between 1885 and 1900. The writers are not always careful to give correct names, hence it is difficult to trace the history of any one, although a search of local newspaper files and court house records would reveal interesting bits of local history.

196 'This and later information obtained from Minutes of the meetings of the Board of Directors. 
marketed all their fruit through the association. ${ }^{197}$ During the early years there does not seem to have been any definite policy of building a reserve out of earnings. The Minutes of the meetings of the Board of Directors contain repeated references to difficulties in getting adequate funds. It was not until 1913 that a definite policy seems to have been adopted. At that time the Board of Directors was authorized to use onehalf of the net earnings for the purpose of building up working capital until such time as a change in this policy should seem advisable. In connection with this decision it was also provided that the members should be given specific credit in a retained dividend account and that their apportioned share should be payable in case of withdrawal or dismissal from the association. This latter provision was, however, canceled at the following annual meeting in December, $1914 .{ }^{198}$ The policy of building up an adequate reserve was continued until, at the annual meeting in December, 1920, it was decided to make it a revolving fund in accordance with the plan developed by the California Fruit Exchange. This revolving fund has grown rapidly and amounted to $\$ 170,740$ in 1930 .

An interesting development was the establishment of a field service in 1924. In carrying on this field service it advises and assists the producers in their growing, harvesting, packing, and grading activities.

The association undertook its first pooling operations in 1925 in its packing house at Monte Rio. Prior to that time fruit had been sold and accounted for as individual lots, often under separate brands. Since that time the proportion of its fruit handled on a pooled basis has gradually increased. A number of brands are used. The one chosen for the best quality is the Covered Wagon brand which comes up to the requirements of the Blue Anchor label.

The Newcastle Fruit Growers' Association is one of the largest and financially strongest locals of the California Fruit Exchange. It has enjoyed good leadership and has also contributed in a large measure to the leadership of the central organization. Its first manager was G. H. Cutter, who afterwards became president of the California Fruit Exchange; its second manager was J. L. Nagle, who later became general manager of the California Fruit Exchange; its third manager, A. T. Wortman, was placed in charge of the Supply Department of the Exchange in 1916. Furthermore, in 1926 its president, J. J. Bremnan, was also made president of the California Fruit Exchange.

197 The gains on the first year's business were $\$ 592$. These were apportioned to members on the basis of the value of fruit shipped. Gains on nonmembers' fruit were to become "common property of the association." Minutes of the Board of Directors, March 22, 1902.

198 Annual meeting of December, 1914, from the typed Minutes of the secretary of the Board of Directors. 


\section{COOPERATIVE MOVEMENT IN THE WATSONVILLE REGION}

As early as July, 1894, a cooperative marketing association for the handling of apples and other fruit was organized in the Watsonville region. ${ }^{199}$ This association was called the Pajaro Valley Fruit Exchange. It was established at the time when the drive for the creation of local exchanges as a foundation for the desired state Fruit Exchange was going on in California under the leadership of E. F. Adams and others. Probably it was a result of this organizational work.

The Pajaro Valley Fruit Exchange was formed as a stock association with headquarters in the city of Watsonville. Its authorized capital stock amounted to $\$ 50,000$, divided into 10,000 shares of $\$ 5$ each. Interest on this capital stock was limited to 8 per cent.

The organization operated for a number of years. ${ }^{200}$ It handled apples as well as dried prunes. As far as its apple business is concerned, it seems to have shipped through Porter Bros.

After the Pajaro Valley Fruit Exchange had gone out of business in June, 1903, it seems that for a long time no cooperative association existed in the Watsonville region. An attempt on the part of the California Fruit Exchange in 1909 to build up cooperative units at Watsonville and Aromas was unsuccessful. In the following year, however, it succeeded in setting up the Aromas Fruit Growers' Association, but no information is at hand to indicate that this continued for more than a season or two. The Exchange at various times repeated its efforts to form an association at Watsonville, but apparently in vain, for it has had no local at that point in recent years.

The idea of cooperative marketing again gained ground in the Watsonville region in 1913. In that year, in several districts of the region a number of fruit growers decided to grade, pack, store, and sell their products together. Three local associations were formed. In 1914 two more came into existence. The three associations which began to operate in 1913 were established in the Corralitos, Casserly, and Carlton districts. They were all nonstock associations. But the Loma Fruit Company, formed in 1914, and the Aptos Fruit Growers' Association, created in 1915, were both built up on a capital-stock basis. Apart from this

199 Pacific Rural Press 47:460. 1894.

200 A news item indicates that it was expected to ship about 40,000 boxes of apples in the season 1897. (Pacific Rural Press 54:308. 1897.) Another mention was found indicating that it was shipping apples in March, 1898. (Pacific Rural Press 55:147. 1898.) In June, 1903, the stockholders decided to disincorporate and divide the assets valued at about $\$ 1,500$. (Pacific Rural Press 65:407. 1903.) 
difference, all five associations showed many similar features in their structure and plan of operation.

The development and experiences of the Corralitos Fruit Growers Incorporated and the Loma Fruit Company are more or less typical of other associations in the region. Of the five associations mentioned they are, by the way, the only two that have remained in existence. The Carlton association functioned only during the 1913 season. The Casserly association was active until about 1922, and the Aptos until about 1925.

Corralitos Fruit Grou:ers Incorporated.-As mentioned above, this enterprise belongs to the group of nonstock associations which were organized in 1913. It was incorporated under the California Non-Profit Corporation Law of 1909. Its first name was Corralitos Fruit Growers' Association, but in 1919 the name was changed to Corralitos Fruit Growers Incorporated. The association's headquarters were at first in Corralitos, but since 1916 in Watsonville.

It is interesting to note the early voting provisions. The members were to exercise the voting power on the basis of one vote for each acre of bearing apple trees. This provision was, however, not to be enforced unless specifically demanded. On ordinary matters each member was to have one vote.

Those orchardists who joined the organization had to agree that they would market all their fruit through the association. According to the contract in force since 1919, they are entitled to withdraw on or before March 1 of any year. But no withdrawal is permitted unless the grower has delivered his crop during at least three seasons.

The association has the right to market the products of its members in its own name and under its own brands. In 1913 it adopted the Black Cat label. Another label which it developed is the Medal Brand. At the beginning it shipped on consignment, but since the fall of 1914 efforts were made to develop f.o.b. sales. Since about that time the organization lias also pooled the apples of its members. At one time it operated packing houses at Corralitos, Aromas, and Watsonville. But since 1918 the grading, packing, and drying of the fruit have been concentrated in Watsonville.

During the first years of its operation the financing was accomplished by the charges made against the members for the sorting, packing, drying, and selling of the fruit, by membership fees, and by loans from commercial banks. When the association borrowed from the banks the directors had to sign personal notes as security for the loans. 
During the first few years the association created no reserve. At the annual meeting in 1916 it was decided to leave it to the option of the individual members to take out the rebate or leave it in the organization to draw interest. In the same year the by-laws were changed to the effect that a reserve could be accumulated at the discretion of the Board of Directors. The directors were authorized to postpone, whenever they thought it advisable, the distribution of any surphus. At no time, however, were such withholdings to exceed the sum of $\$ 20,000$. They were to be passed to the credit of the members and treated as a loan with interest at 7 per cent per annum. Furthermore, certificates of indebtedness were ordered to be issued to each member at the end of the fiscal year showing the amount due to them on account of the money withheld.

In 1918 it was decided to change the organization from a nonstock association to a capital stock corporation. It seems that the promoters of this change thought the issuing of stock was a way of supplying the association with cheaper capital, facilitating the borrowing of money from the banks, and avoiding the payments of interest to people holding certificates of indebtedness who were no longer members of the association.

The organization was authorized to issue capital stock to the amount of $\$ 75,000$ in shares of $\$ 10$ each. It may limit the issuance of stock to the number of acres of apple trees owned or controlled by the applicant for membership. Of the authorized capital stock there were outstanding on June 1, 1931, shares to the amount of $\$ 33,550$. At the same time, the association had accumulated a reserve of about $\$ 10.000$. During the first few years interest was paid on capital stock. This policy was later abandoned.

During 1913 and 1914 the association comprised only orchardists in the Corralitos district. In the spring of 1915 it was, however, decided to take in growers from outside the district. Around 1924 about 60 growers seem to have belonged to it. Dissatisfaction with returns led to some withdrawals, leaving in 1931 only about 25 orchardists selling through the association. The number of stockholders is larger.

The association handles some business for nonmembers, but makes refunds only to members. It handles both fresh and dried apples and has recently also sold some apples in frozen form.

In the early years it bought spray material and shook for its members, but recently it has furnished only boxes.

Loma Fruit Company.-This organization was originally a private packing company which in 1914 was taken over by a group of orchardists who wanted to sell their crops on a cooperative basis. They decided 
to form a capital stock association, and thereby deviated from the plan of organization of those cooperatives which had come into existence the year before.

The authorized capital was fixed at $\$ 50,000$ divided into 500 shares. The growers had to subscribe for them on the basis of 7 cents per loose box for the normal annual production of apples in their orchards. Instead of paying up the subscribed stock immediately they delivered promissory notes and agreed that payments should be made by deductions from the earnings of the association due to them.

As in the case of the Corralitos association, the growers have to agree to sell all their apples through the association. Any grower may, however, temporarily sell outside if he files a request with the association prior to June 1 of any year. In such case he is expected to pay a maintenance fee by which he contributes to the overhead expenses on the basis of the estimated production of packed boxes.

The association handles apples and pears in fresh or dried form and has also recently gone into the business of packing frozen apples used for pie making. As another sideline, it took up in 1924 the liandling of lettuce for another local association, the Watsonville Vegetable Growers. In addition to a charge to cover the cost of grading and packing, it charges 10 per cent commission on the gross sales price for selling. It has sold largely through brokers.

The Loma association has two packing houses and an evaporating plant. In connection with the packing of the fruit it also supplies the necessary boxes, which it buys in the open market.

In the early years of its existence the association occasionally sent cars unsold when this seemed to be advantageous. This policy has, however, been abandoned. Efforts have been made to increase the f.o.b. sales as much as possible, with the result that today a large portion of the fruit is handled on that basis. The apples from this region are now sold mainly in the Los Angeles, San Francisco, and other California markets.

For some time the fresh fruit was pooled but the practice was discontinued. The main reason given for its discontinuance is that there is too much difference in the quality of the fruit of the various growers. The Corralitos association, however, has maintained the pooling of its fresh fruit, as did the Casserly and the Aptos associations while these were in existence. As far as dried fruit is concerned, the Loma Fruit Company applies the pooling method.

Advances made by the organization during the last few years have amounted to 10 cents a box, a rate which is held to cover the expenses of picking and hauling the fruit to the packing house. Like the Corralitos 
association the Loma Fruit Company at first distributed all its profits on a patronage basis and realized only after some experience that it was advisable to accumulate a reserve fund. In 1918 the by-laws were amended to provide that a charge of not more than 1 cent per loose box of apples delivered should be made each year and be deducted from the grower's returns in order to build up a reserve. At the same time, a guarantee was created for all f.o.b. sales made by the association. The Board of Directors was empowered to guarantee such sales and to make any payments resulting therefrom out of the reserve fund. In accordance with this provision the association has built up what it calls a "Guarantee Reserve Fund."

When the second packing house was bought in 1919 an assessment of 4 cents per loose box for all fruit delivered in 1919 and 1920 was made in order to provide the money necessary for the purchase. The Loma Fruit Company has not paid any interest on capital stock during recent years.

The by-laws of the association provide for a Committee of Crop Estimates which is entrusted with the task of inspecting the orchards of stockholders or persons desiring to become members and to determine what amount of fruit may be produced therein. Only about 25 growers shipped through the association during the 1931 season.

Collaboration Between Cooperatives.-As early as 1913 an endeavor was made to get the cooperative associations which had sprung up in the various districts to work together. It was hoped that eventually a joint agency would be developed because it was recognized that much more could be accomplished if the growers would cooperate to that extent. Some collaboration actually took place, but the idea of establishing a joint marketing agency for the selling of the fruit and the purchasing of the necessary supplies was never carried out.

The Corralitos and the Casserly associations bought shook together in 1915 and during the season of 1918 the same two organizations sorted, packed, and sold their fruit jointly.

Reasons for Dissolutions. - From the above it is evident that cooperative marketing among the orchardists in the Watsonville area has not proceeded very far. The two cooperatives that are now functioning comprise only a small number of orchardists, and the business liandled by them represents a very moderate percentage of the total fresh fruit shipped out of the area.

The reasons for the discontinuance of the Carlton, Casserly, and Aptos associations are manifold. They include dissatisfaction arising out of mistakes made at the beginning, high overhead costs arising in 
part out of decreased volume of business which followed early disappointments or lack of support by growers, individualism, suspicion, and insufficient knowledge of the principles of cooperative marketing.

One important additional factor which has retarded the development of cooperative marketing in the Watsonville region is the position of the independent packers who are mostly of Slavonian origin. Practically all these packers bought apples on the tree. Later on they leased orchards, and finally many of them have bought land with the result that they control about 60 per cent or more of the production in the Pajaro Valley. ${ }^{201}$ In addition many of the independent growers are of the same racial stock and are predisposed to deal with the packers rather than to cooperate.

\section{SEBASTOPOL APPLE GROWERS' UNION}

Organization.-Early in 1911, a group of growers of Gravenstein apples in the Sebastopol region decided to organize a cooperative marketing association. The immediate reasons for this decision were the belief that the packers were making large profits; the expectation that the growers could share in these profits and increase their returns by marketing their fruits themselves; the belief that improvements in the grading of the apples were desirable; and the desire to obtain savings by joint buying of supplies.

The Sebastopol Apple Growers' Union was formed as a capital stock organization with an authorized capital of $\$ 50,000$ which was later extended to $\$ 200,000$. Each share was to have a par value of $\$ 10$. At first, members were not allowed to own more than $\$ 50$ worth of stock. But this restriction was changed several times with the result that since 1920 a member may hold capital stock to the amount of $\$ 300$. The stock was allotted to the growers according to the fruit delivered and was paid for by means of deductions made from the proceeds of the apples marketed through the organization on the basis of 5 cents a box.

Policies.-The directors were at first elected for one year, but in 1918 it was arranged that five directors should be elected for two years and four for one year, and that, thereafter, all directors should be elected for two years. The original contract which provided that the growers had to deliver all their fruit to the organization was to continue from year to year. However, the growers were allowed to withdraw in any year upon written or personal notice to the organization between February

201 In regard to the marketing practices of the independent packers in the Watsonville area, see: Stokdyk, E. A., H. E. Erdman, Charles H. West, and F. W. Allen. Marketing California apples. California Agr. Exp. Sta. Bul. 501:108-112 and 120-121. 1930. 
10 and $20 . \Lambda$ clause in the contract provided that in case the contract was violated the grower was to pay the association 15 cents a box. This rate was later increased to 50 cents.

The organization has followed the policy of selling mostly through brokers in the carlot markets in the United States and Canada, and to exporters in case of shipments to other countries. It has favored the development of f.o.b. sales, and has endeavored to sell as much fruit on this basis as possible.

At first, it made returns for the Gravensteins, which represent the bulk of its business, in two pools. In 1920 it was decided to have only one pool for the entire season. One reason for this change was that the growers were inclined to pick and deliver immature fruit near the close of the first pool because prices in the second pool were usually lower than in the first. The adoption of the one-pool system did away with this difficulty, but led to dissatisfaction among growers in the northern part of the Sebastopol area where apples generally mature a little earlier than in the southern part. These growers therefore felt that the one-pool system deprived them of a price advantage which such earlier maturity gave them. This dissatisfaction was later to be an important reason for heavy withdrawals from the Union.

The volume of business of the Union grew constantly up to 1923 when the Union controlled over 70 per cent of all the Gravensteins shipped out of Sonoma County. In that year it shipped 1,051,765 boxes of apples, of which 879,560 were Gravensteins. With the increase in the quantity of apples handled by the Union, and the spread of its activities over a larger territory, a need arose for more packing houses. By 1919 it operated five packing houses, and by 1923 a total of eleven, which were located as follows: two in Sebastopol, two in Santa Rosa, and one each in Graton, Forestville, Molino, Sago, Barlow, Stoney Point, and Trenton.

Apart from selling for its members, the Union has also been engaged in purchasing box shook, fertilizers, and spray material. In connection with this latter activity, the Union in 1920 and 1921 considered taking up the manufacturing of lime-sulfur spray. The matter was dropped, however, at that time and has not been taken up again. When the Union delivers fertilizer and spray material the members are given credit until the proceeds of the crop come in. Payment is then made by deductions from the returns.

In 1915 it was decided to ereate a reserve by charging $2 \frac{1}{2}$ cents a box against all apples marketed throngh the Union. In connection with this plan it was later provided that these deductions should be placed to the credit of the different growers and that 6 per cent interest should be 
paid thereon. Early in 1919, the decision was made to issue capital stock against the various amounts accredited to the members. Since that time the Union has continued to finance itself by withholding from 2 to 10 cents a packed box and issuing stock for the amounts so withheld. Under this policy the issue of capital stock increased until at the end of 1923 shares to the amount of about $\$ 194,000$ were outstanding. A large portion of this money was used to build the necessary new packinghouse facilities.

Since 1924, proposals have been made in the Union to redeem the capital stock held by nonproducers and to keep the stock in the hands of members actually delivering in proportion to the amount of fruit which they market through the Union. The first proposal of this kind was made at the annual meeting in February, 1924. It was then recommended to purchase immediately at par value any stock held by nonproducers, to create a fund for this purpose, and to reissue the stock to growers. The proposal was adopted, but decisive steps to carry out the proposal were not taken until October, 1927, when it was resolved to create a revolving fund by deductions from the proceeds of sales. Following this, it was provided in December, 1928, that all stockholders should be permitted to surrender their stock upon the following terms:

1. A price of $\$ 6$ a share was to be paid in cash, the balance in certificates of indebtedness payable on or before five years.

2. Stock was to be issued to present stockholders who had delivered apples during the 1927 and 1928 seasons to the amount accredited to them in the revolving fund accumulated in 1927 and 1928.

It was further provided at that time that in succeeding years additional capital stock was to be issued against any deductions and that, in the event the owner failed to deliver his entire crop to the association, he agreed to surrender the new stock to the Union at $\$ 5$ a share. Should a nongrower acquire new stock the Union was to be entitled to buy it at $\$ 5$ a share.

This revolving finance plan has helped to readjust the holdings of stock so that the stock is now distributed more nearly in accordance with the quantities of apples delivered by the members. This change has, however, not settled the controversy over the system of voting. The demand for the one-man-one-vote provision is still active in the Union. To arrive at a better solution it was proposed in 1929 to create a combination of equal voting power with a tonnage vote, the latter to be applied only in specific cases. But so far no action has been taken on this proposal. 
It will be remembered that the restrictions on the number of shares which any member may own were changed (page 79) so that finally shares to the amount of $\$ 300$ could be held by one owner. Partly because of this a considerable amount of stock accumulated in the hands of $a^{\circ}$ small group of members who were heavy shippers, and who, by accumulating their votes in the election of directors, were able to control the organization. In 1923 it was said that although the Union had more than 500 members it was actually controlled by about 75 . Those who were dissatisfied with this situation asked that the Union be changed into a nonstock association and that the voting power be put on a one-man-onevote basis. Although a majority of the members favored such a change, the opposition was strong enough to maintain the capital-stock structure when the question was taken up in 1923 and 1924.

Growth of Dissatisfaction.-The dissatisfaction which resulted from the defeat of the one-man-one-vote plan aggravated the discontent which had already developed over the abandonment of the two-pool system. Other difficulties which the organization experienced around 1923 were the occurrence of congestion at some of the packing plants during the height of the season, the demand on the part of many growers that the Union take care of the culls, which it had so far failed to do, and a certain amount of dissatisfaction among the members with the sales system and management of the organization.

These grievances led to open agitation against the Union in the fall of 1923. The returns for the crop of 1922 and 1923 had been relatively poor. Smarting under low prices, many growers blamed the Union for the poor returns. In September, 1923, a group of approximately 150 growers from Forestville, Graton, and Trenton assembled and adopted the following resolutions :

First, Resolved that we will not submit to the present management of our organization for another year.

Second, Resolved that our apples be sold through the California Fruit Exchange. Third, Resolved that we go back to the two-pool system.

Fourth, Resolved that salaries and expenses be reduced where it can possibly be done.202

In the midst of these troubles a committee of nine consisting of orchardists, bankers, and merchants was appointed and charged with the task of making a thorough investigation of the apple industry, and to submit findings to the Union in order to enable it to overcome its difficulties. This committee studied the marketing methods and other

202 Sebastopol Journal. p. 1. September 18, 1923. 
questions pertaining to the apple industry in California and in the Pacific Northwest. Since some difference of opinion developed among its members, two reports were finally submitted in December, 1923. Among other things, the majority report recommended:

1. Instead of further developing the system of selling through brokers, to sell all apples handled by the Union through the California Fruit Exchange with the exception of those which may be marketed in California and foreign markets (not including Canada).

2. To contemplate the packing of an extra fancy apple and to consider the employment of their own inspectors.

3. To start an intelligent system of advertising and to build up an advertising fund for 1924 by setting aside 1 cent per box of Gravensteins.

4. Not to return to the two-pool system abandoned a few years ago for the reason that, in case of two pools, growers having a considerable percentage of their crops in the first pool would reap only slight, if any, benefits in actual returns; that additional expenses would be incurred; and that a desire on the part of many growers would develop to hasten into the first pool to the detriment of a high standard of picking and packing.

5. To investigate the necessity, advisability, and practicability of building one or more precooling and cold storage plants.

6. To adopt some particular and outstanding brand and to abstain from using the present label until the season is well advanced and the apples have attained a sufficient percentage of color to conform with the label.

7. To change the organization to a nonstock association with a oneman-one-vote system.

8. To investigate the possibilities of canning and drying cull apples.

The minority report, although not clear in its expression and apparently influenced by personal feelings, recommended the maintenance of the independent brokerage selling system rather than joining the California Fruit Exchange. When the members were asked to vote on the two reports, 7,192 shares were cast for the majority report and 7,515 shares for the minority report. Thus the followers of the minority report won out by a very narrow margin. For some time it looked as if a compromise could be reached between the two almost equally strong groups. A proposal was made to let the California Fruit Exchange handle 50 per cent of the volume of the crop packed by the Union and to sell the 
other half through brokers as before. ${ }^{203}$ The California Fruit Exchange refused to handle less than the entire crop of apples controlled by the Union.

As no satisfactory agreement could be reached between the dissenting groups, a considerable number of growers, primarily the Forestville group, left the Union and formed a cooperative organization of their own. By this split the Union lost about 20 per cent of its former membership and business. The occurrence of the split also led a number of private firms to start shipping apples from the Sebastopol area, with the result that the business was divided up more and more between competing units. By 1926, the Union comprised about 400 growers and controlled only about 35 per cent of the Gravenstein crop as compared with 70 per cent in 1923 .

In recent years the Union has gäined back some of its loss in membership and business. In the 1931 shipping season it served more than 500 members and marketed about 40 per cent of the Gravenstein crop shipped out of Sonoma County.

\section{'THE GRAVENSTEIN APPLE GROWERS' ASSOCIATION}

The group of dissatisfied growers which withdrew from the Sebastopol Apple Growers' Union in the spring of 1924 at once formed the Gravenstein Apple Growers' Cooperative Association of Sonoma County with headquarters in Forestville. As mentioned before (page 80), this group consisted primarily of growers in the area in which apples mature somewhat earlier, but included some from several other areas as well.

The new cooperative naturally adopted some of the recommendations of the majority report of the committee appointed the previous year to study the Union. (See pages 82 to 83.) Thus it was established as a nonstock association with equal voting power for every member. Its by-laws provided that the territory should be divided into districts and that each district should elect one director.

Moreover the association immediately joined the California Fruit Exchange, a line of action which the report had particularly recommended to the Union.

Since the by-laws were drafted in anticipation of the connection with the California Fruit Exchange, they deal with the marketing contract to be effected with the Exchange. According to the stipulations in the by-laws, the Board of Directors is empowered to make a contract for

203 The offer made by the Sebastopol $\Lambda$ pple Grower's' Union to the California Fruit Exchange also involved a reservation of the right to sell through brokers in New York, Chicago, and certain other specified markets. 
each year unless the majority of the members decides at a special meeting to discontinue the marketing agreement. Furthermore, there is a provision for the creation of a withholding fund after the pattern of the withholding fund developed by the Exchange.

In its first shipping season the organization had only a little more than 60 members. By 1926, its membership had increased to about 165 . Approximately the same number of growers marketed their apples through it in the 1931 season. During the latter season, the association handled 262,000 boxes of Gravensteins representing approximately 20 per cent of all the Gravensteins shipped out of Sonoma County.

In the 1924 and 1925 shipping seasons, the apples were handled on a weekly pool basis. In 1926, the crop was divided into two equal pools. In order to avoid one of the difficulties encountered by the Union when it operated on a two-pool basis (see page 80 ), the new association did not determine length of the pooling period until the end of the marketing season. The rush to get into the first pool was thus avoided. In some of the following seasons, the association has operated on a one-pool basis. In 1931, however, it went back to the two-pool plan.

The necessary financing is done by making deductions from the proceeds of sales at a rate determined from time to time by the Board of Directors. On January 1, 1931, its Withholdings Repayable Account amounted to more than $\$ 60,000$. The membership fee of $\$ 10$ provides a negligible share of the necessary funds.

The organization has four packing houses, one each in Forestville, Graton, Trenton, and Sebastopol. In 1931 its headquarters were moved to Sebastopol.

\section{THE CALIFORNIA GRAVENSTEIN APPLE GROWERS}

Because of the split in the Sebastopol Apple Growers' Union in 1924, cooperative marketing among the apple growers of the Sebastopol area suffered a decided setback from which it has not yet recovered. In 1923 over 70 per cent of the Gravenstein apples were handled by one marketing organization covering the whole area, while since 1924 the percentage marketed cooperatively has been very much lower. By 1926, the two cooperatives discussed above controlled scarcely 50 per cent of the Gravenstein crop. At the same time, some 15 independent shippers participated in the apple business as a result of the rift in the ranks of the Union. The division of the business among so many competing units attracted attention in the fall of 1926 when attempts were made to explain the low returns for that year's crop. 
The discussions of the marketing problem which took place at that time resulted in the appointment of 16 small committees in as many communities. The members of these committees met in Sebastopol in November, 1926, to consider ways and means of developing an improved method of marketing. Out of this gathering grew a smaller committee of 16 which appointed a still smaller group of 5 for the purpose of working out a plan for a new organization. Several plans had been proposed during the preceding months. These centered around two main ideas, namely, (1) that the growers should proceed alone and aim at the perfection of their cooperative marketing system, or (2) that the growers and independent marketing agencies should unite their forces.

In this committee work the idea of reconciling the two main cooperative groups ${ }^{204}$ and of establishing one large cooperative enterprise was soon given up. It quickly became clear that the Sebastopol Apple Growers' Union would not join a new organization unless 90 per cent of the crop were signed up. The committee did not consider it possible to get such a degree of control because of the large acreage owned by some shippers who could not be expected to join. The other main idea was therefore followed, namely, the proposal that a combination should be effected of cooperative growers and independent dealers. As a result the committee drew up a marketing scheme which led to the formation of a new organization, the California Gravenstein Apple Growers, the most essential feature of which was the establishment and operation of a clearing house. This marketing scheme will be discussed in a later section $^{205}$ (see pages 112 to 116 ).

The idea of establishing one large cooperative apple marketing organization for the Sebastopol area was, however, not given up. It was revived soon after the clearing-house plan had failed in its second season. The immediate cause of the revival of this idea was the work of another research committee, which had been appointed in the early spring of 1929 for the purpose of developing a better plan of operation than the one which had been followed in 1927 and 1928. ${ }^{206}$

In January, 1930, the committee brought forth its recommendations $\mathrm{s}^{207}$ after expressing its belief that "the problems our industry faces can only be met by cooperative grower effort" and that "a set-up including

204 There had also developed a few smaller cooperative groups. One of these, the Sonoma Valley Apple Growers, was involved in these deliberations and in the resulting organization.

205 See also: Stokdyk, E. A., H. E. Erdman, Charles H. West, and F. W. Allen. Marketing California apples. California Exp. Sta. Bul. 501:105-107. 1930.

206 The following persons were on the committee: E. C. Winkler, Chairman, A. W. Banks, R. E. Ohlman, Chas. H. King, and F. P. Bailey.

20i Sunta Rosa Press Democrat. p. 1. January 26, 1930. 
cooperative and independent packers as in our existing organization is unnatural and doomed to failure as there is a divergence of interests that cannot be reconciled." It concluded :

We therefore recommend that "central" be revamped to provide for the following:

The election of nine directors from nine districts, the boundaries of which are to be equitably determined.

That the directors appoint a general manager; that the organization purchase after appraisal the plants and equipment of the Sebastopol Apple Growers' Union and the Gravenstein Apple Growers' Cooperative Association and of such independent packers as may be deemed advisable.

Such purchase to be financed by the issuance of certificates of indebtedness similar to those used by the Poultry Producers' Association and other successful cooperatives. That grower financing be provided for.

This plan has the endorsement of the Federal Farm Board and is the type of organization eligible for the financial assistance should same be necessary or desirable.

Provision also to be made for affiliation with the organization on mutually satisfactory basis of other cooperative packers and grower packers.

The report was submitted to a mass meeting of growers held in Sebastopol in January, 1930, and adopted by an overwhelming majority of those present. But no action was taken to carry out its recommendations because the merger plan did not get sufficient support at the subsequent annual meetings of the two cooperatives involved. The main difficulties which prevented the realization of the plan of one big cooperative for the Sebastopol area were personal considerations, old prejudices, and insufficient insight into the importance of the proposal on the part of the rank and file of the growers.

\section{GROWERS' COOPERATIVE AGENCY}

One interesting venture deserves special consideration because it is one of two known attempts on the part of California fruit growers to go into the business of jobbing fruit to the retail trade through the formation of an association which was to be supported by various local cooperative organizations. The name of the organization was the Growers' Cooperative Agency established in San Francisco some time in the early spring of $1902 .{ }^{208}$

The movement to organize began in the summer of 1901 with the formation of the Sacramento River Cooperators ${ }^{209}$ in the vicinity of Walnut Grove and Courtland. The immediate reason for its formation

208 The other attempt mentioned was that of a group of citrus growers who adopted the same sort of a plan in the Oakland market in the fall of 1924.

209 California Fruit Grower, 26(685):4. 1901. 
seems to have been an increase in the commission rates on the San Francisco market from 8 per cent to 10 per cent. ${ }^{210}$ There were, however, numerous other reasons. At the Twenty-sixth Fruit Growers' Convention held in December, 1901, the convention adopted the report of a committee on "The State of the San Francisco and other Coast Markets." It read as follows :

\section{To the State Horticultural Convention:}

Your committee, to whom was referred the state of the San Franciseo and other coast markets, beg leave to report as follows:

In our opinion the present custom of selling fruit and produce in these markets is wasteful and unnecessarily very expensive, more especially in the following particulars:

First: The grower, at time of shipment, does not know the quantity of competing produce which his shipment will meet-resulting often in seriously over stocking the markets.

Second: He has no assurance of fair treatment at all times.

Third: The charges upon the produce for freight and drayage, owing to shipment in small amounts, is a serious burden in excess of the ten per cent brokerage; and added to this is the careless loss of boxes which should be returned to the shipper.

Fourth: The work of selling is now so complicated and conducted by such a multitude of brokerage firms that it may perhaps be doubted if these men ean afford to do the work at much less than the present rate; and to maintain this, which they say is but a living rate, they have determined to cooperate, and are doing so most effectively.

Your committee, therefore, sees no way by which these evils can be remedied except by the cooperation of growers who ship to these coast markets. They alone must control both the distribution and the sale of their products, or suffer the present evils.

To this end we recommend:

First: That the growers form local associations in their several localities for taking charge of the assembling and shipment of produce designed for coast markets, to control as largely as possible the total output at such places.

Second: That these several local associations elect representatives, who shall make such arrangements for shipment and sale as the interests of the producers may require.

We further recommend that a committee of five be appointed by this Convention, to promote the formation of the above-named organizations.
A. R. Sprague,
F. M. RIGHTER,
C. GaInes.

Upon motion, the report was adopted by the Convention.211

The Sacramento River Cooperators was formally incorporated in April, 1902, ${ }^{212}$ and shortly started in business by opening a store in San

210 California Fruit Grower, 27(741):2. 1902.

211 'Twenty-sixth Fruit Growers' Convention, Official Report. p. 92. December, 1901.

212 Articles of Ineorporation filed in the Court House, Sacramento, A pril 7, 1902. 
Francisco under the name of the Growers' Cooperative Agency. The progress of the organization is outlined in the report made by $A$. $R$. Sprague as Chairman, presumably of the above-mentioned committee, and presented at the Twenty-seventh Fruit Growers' Convention held in December, 1902.

\section{To the State Convention of Fruit-Growers of California:}

Gentlemen: Your committee to whom was referred the state of the San Francisco market, with instructions to proceed to organize upon the plan reported to the last State Convention of Fruit-Growers, beg leave to make the following report:

We started the work of organization first upon the Sacramento River, because that was the ehief section from which perishable products are shipped to the San Francisco market. It was late in the season before an organization of the Sacramento River growers could be secured, and while it was proposed that this organization should be but one of several that should be centralized for the conduct of cooperative marketing in San Francisco, the season had already become so late that if anything was to be done during the summer of 1902 , it was clearly evident that the Sacramento growers would have to take the lead. This they did and proceeded to rent a store and equip it for business. A large number of the heaviest growers on the Sacramento River were included in this organization, and shipped very freely to it. The membership of the California Fresh Fruit Exchange from the various sections where associations are established also shipped to this house, which was known as the "Growers" Cooperative Agency." The business was entirely satisfactory and giving an excellent profit until somewhat past mid-season, when the action of the San Francisco commission merchants put in force a boycott, which rendered it exceedingly difficult for the Growers' Cooperative Agency to do business. Of course, it is well known that while responsibility for the boycott is difficult to fix, its effects may be clearly traced. The retailers and peddlers were instrueted that they would be unable to buy any supplies of the members of the Commission Merchants' Association if they did any business with the Growers' Cooperative Agency. This extended even to dealers at San Jose, and other points. A suit has been brought which is now before the State courts, to secure a withdrawal of the boycott and for damages resulting from it.

At various times the growers have endeavored to secure of the commission merchants permission to do a cooperative business for themselves in the San Francisco market, but this has been in each instance refused and met with the declaration that it would be necessary for the growers to disincorporate and refuse entirely to do business upon the cooperative plan, or they would not be permitted to sell their own wares in San Francisco. In the opinion of your committee, no other resource is left to the growers of California, who ship to the San Francisco market, than to extend the work of organizing local associations, and centralize these into an organization which shall conduct the business of selling perishable products in the San Francisco market. They would also recommend that the present law providing for a free market be made effective, and provision be made for opening the same without delay.

Respectfully submitted,

\section{A. R. Sprague}

Chairman of Committee.213

213 Twenty-seventh California Fruit Growers' Convention, December, 1902. California State Board of Horticulture, Biennial Report 1901-02:369-371. 
The above-mentioned boycott consisted in an organized refusal on the part of the jobbers to sell to retailers who patronized the Growers' Cooperative Agency. The boycott of the dealers became so serious that an attempt was made to break it up by special legislation against boycotting on state property. ${ }^{214}$ Furthermore, legal action was brought against the dealers. ${ }^{215}$

The support of the various fruit growers' organizations apparently did not lead to the development of other local associations. The Growers' Cooperative Agency itself was not incorporated until August, 1904. The organization handled not only fruits, but also vegetables grown by its members, including cantaloupes, beans, potatoes, and asparagus, coming mainly from the area between Isleton and Courtland.

It seems that the major difficulty of the organization arose from the fact that it had too limited a line of fruits and vegetables, and during the winter months "kept open merely in anticipation." ${ }^{216}$ Retailers had to obtain most of their supplies during parts of the year from independent jobbers, and in certain lines had to obtain all of their supplies from these dealers. The retailers were therefore at the mercy of the jobbers from whom they bought the major portion of their supplies. The Agency was also handicapped by lukewarm support from growers. Competitors solicited split shipments, and doubtless in numerous cases manipulated returns made to members of the Agency.

The Growers' Cooperative Agency continued to function until some time in 1906 when the directors decided to discontinue operations. ${ }^{217}$

\section{RECENT PLANS OF COMBINING GROWERS' AND DEALERS' INTERESTS}

\section{SUMMARY OF EARLY PLANS}

'The first notable example of a combination of fruit dealers and growers in California was that of the California Fruit Union already discussed (pages 13 to 29). The California Fruit Growers' and Shippers' Association also discussed above (pages 29 to 36 ) was another example. During practically the entire existence of the latter organization there was agitation for the formation of a growers' association. Such an

214 See: Pacific Rural Press 65:146. 1903. The Act referred to was Chapter LXVI, California Statutes of 1903. For a discussion of the boycott see: Reynolds, A. T. J. Cooperative selling. Pacific Rural Press 65:260-61. 1903.

215 Pacific Rural Press 65:114. 1903.

216 San Francisco Chronicle 77(85):76. April 10, 1903.

217 Statement of A. T. J. Reynolds, November 11, 1932. Mr. Reynolds' memory was not clear on the date, but seemed to be very definite on the point that the discontinuance followed soon after the San Francisco earthquake. 
organization appeared with the formation of the California Fresh Fruit Exchange in 1901. The idea of joint action has continued to be a matter of discussion and has led to the establishment of numerous organizations, some of which have actually operated agricultural clearing houses. ${ }^{218}$

There are various reasons for the appearance and adoption of new combination schemes: (1) The unsatisfactory experiences of the days of the California Fruit Union and the California Fruit Growers' and Shippers' Association were soon forgotten. (2) The rapid growth of the industry meant that every year of good crops was one of demoralized markets and complaints of unsatisfactory returns; the increase in the number of shippers made matters worse and led to an increasing demand for the regulation of the fresh-fruit shipments to the East by some one organization. (3) Cooperation among the fresh-fruit growers made relatively slower progress than was hoped by the promoters of cooperative marketing. (4) A sudden decision on the part of the Southern California Fruit Exchange to join the California Fruit Agency influenced the policy adopted by the northern cooperative fresh-fruit growers. (5) The efforts of Weinstock to effect his long-cherished plan of joint action by growers and dealers for control of shipments helped to keep the issue alive.

218 Since the term "clearing house" has been used loosely in the field of agricultural marketing, attention is called to the distinction made here between clearing houses and joint marketing organizations. By an "agricultural clearing house" is meant a combination of marketing agencies having as its main purpose an orderly distribution of farm products, principally through the collection and dissemination of market information. This market information may, but need not necessarily, include recommendations collcerning the adjustment of shipments to existing market demands. Furthermore, the members of the clearing house may, or may not, be bound to follow the recommendations. All this depends upon the strength of the clearing-house agreement. A clearing house, however, is not supposed to make sales or to determine the original routings of shipments. It can only make recommendations, although it may have means of enforcing them. On the other hand, a "joint marketing organization" is a combination of marketing agencies which actually performs selling transactions for its members. In it the menbers have delegated their individual selling function. Between a clearing house using its full power of enforcing its recommendations and a joint marketing organization there may seem to be very little difference. This, however, should not furnish a reason for likewise ealling the latter a clearing house, as is sometimes done.

It may also be worth while to divide clearing houses roughly into two classes: (1) those created for the purpose of furnishing market information and which might be called "information clearing houses"; and (2) those which, in addition, have been given the power to enforce their recommendations. The latter might be called "regulation clearing houses." 


\section{THE CALIFORNIA FRUIT EXCHANGE AS A MEMBER OF THE CALIFORNIA FRUIT DISTRIBUTORS}

In the spring of 1903, the Southern California Fruit Exchange, a growers' citrus organization, decided to join the independent shippers who had formed the California Citrus Union in the formation of a joint selling organization known as the "California Fruit Agency." Since the California Fruit Exchange had been selling through the eastern sales force of the Southern California Fruit Exchange, the new alignment left the deciduous organization without sales connections. The California Fruit Exchange found itself faced with two alternatives, namely, either to establish its own selling agencies in the East, or to affect a similar alliance by joining the California Fruit Distributors. Of these two alternatives, the latter one was chosen. One writer referred to the combination as "The California fruit lambs-lying down with the fruit lions," 219 but seemed to be hopeful of good results. ${ }^{220}$

The experience of the California Fruit Exchange in the marketing season of 1903 was very unsatisfactory. The Exchange complained of excessive auction charges and a confusion of agents at many western points. $^{221}$ Better results were expected for the following year. When these results were not realized the California Fruit Exchange decided to discontinue its connection with the California Fruit Distributors at the end of the 1904 season. On the other hand, the alliance of the southern cooperative citrus-fruit growers with the independent shippers lasted for only one marketing season. ${ }^{222}$ After both cooperative organizations had returned to their previous status they decided in February, 1905, to renew their old agreement, which allowed the California Fruit Exchange to sell its fruit through the sales organization of the Southern California Fruit Exchange, then renamed the California Fruit Growers' Exchange. ${ }^{223}$

219 Editorial in: Pacific Rural Press, 65:354. 1903.

220 Pacific Rural Press 65:370. 1903.

221 Report of the General Manager of the California Fruit Exchange for 1904. (Unpublished.)

222 For an account of the California Fruit Agency, see: McKay, A. W., and W. M. Stevens. Organization and development of a cooperative citrus-fruit marketing agency. U. S. Dept. Agr. Dept. Bul. 1237:12-13. 1925.

MacCurdy, R. M. The history of the California Fruit Growers' Exchange. p. 46-48. 1925. Lloyd, J. W. Cooperative and other organized methods of marketing California horticultural products. Illinois Univ. Studies Social Sci. 8(1):53-65. 1919.

223 Lloyd, J. W. Cooperative and other organized methods of marketing California horticultural products. Illinois Univ. Studies Social Sci. 8(1):67. 1919. 


\section{STATE BUREAU OF DISTRIBUTION}

Weinstock had repeatedly been involved in attempts to combine growers and shippers in order to bring about a better regulation of fresh-fruit shipments to the East. At a meeting held at Lodi on January 15, 1910, under the auspices of the San Joaquin Grape Growers' Association, he was made a member of a committee appointed for the purpose of uniting all the various shipping agencies into one collective body, which should not only regulate shipments, but also establish minimum f.o.b. prices. ${ }^{24}$ The resolutions which were adopted in connection with the appointment of the committee were as follows:

Resolved, that the table grape growers demand that the shipping organizations get together and arrange a collective system of distribution, in order that the fruit may not be forced into competition with itself in the eastern markets, to the loss of the growers, experience having shown that satisfactory results can be obtained only where the distribution is made from this end through one channel....

Resolved, that the shipping organizations be called upon, among other things, to determine a minimum f.o.b. selling price, below which no fruit shall be sold.225

This plan did not succeed, nor was Weinstock able to carry out his idea, although he continued his efforts for some years. Finally, when he was appointed to the position of State Market Director following the passing of the State Commission Market Act in 1915, he again brought up the matter. ${ }^{226}$

Soon after his appointment as State Market Director, he proposed to the citrus-fruit growers, as well as to the fresh-deciduous-fruit growers, the establishment of a state clearing house. The establishment of a clearing house for cantaloupes in the Imperial Valley encouraged him. Although he first wanted to model the clearing house for citrus and fresh deciduous fruits after that for cantaloupes, he was later induced to modify the plan to the extent that the state of California should establish and supervise the agency under the State Commission Market

224 The other members of the committee were J. J. Kindley, of Acampo; H. H. Bennett, of Fresno; J. P. Dargitz, of Acampo; and H. M. Smith, of Lodi.

225 California Fruit Grower 41(1125):5. 1910.

226 Note the following remark made by Weinstock at the Forty-eighth Fruit Growers' Convention held in February, 1916, at San Bernardino:

"I have had that remedy in mind for years as a private citizen. However, I found it impossible to have the remedy put into operation. One thought prompted me to accept this office at the hands of the Governor. One hope led me to undertake this very grave, serious, and burdensome responsibility of acting as your market director and that was the thought that now would be offered me the opportunity, officially, of carrying out the remedy for the weak spot in our marketing in the East, marketing that I have had in mind for years." Forty-eighth Fruit Growers' Convention Proceedings. p. 67. February, 1916. 
Act. This modification was made because some persons objected to his plan on the grounds that the proposed combination of growers and shippers might conflict with the anti-trust laws. By having the state establish and supervise the clearing house, Weinstock hoped that he could avoid any interference with his project on the part of the federal and state authorities.

Weinstock proposed his plan first to the citrus-fruit growers at the Fruit Growers' Convention held in San Bernardino in February, 1916. The plan is well outlined in the form of a pledge which he suggested for submission to the various shipping agencies engaged in the marketing of citrus fruit, this pledge is quoted as follows:

We, the undersigned, hereby agree to become adherents to the State Bureau of Distributors to be organized by the State Marketing Director for the purpose of routing and diverting the eastern citrus fruit shipments in such a manner as to prevent gluts and to get to each market its maximum supply, it being understood that the car dispatcher who is to perform the service of routing and diverting the cars should be nominated in a conference of the representatives of the adherents of the State Bureau of Distributors and appointed by the State Market Director, it being further understood that the Market Director will appoint as an advisory council to the car dispatcher such representatives of the adherents as by them may be chosen, it being further understood that the adherents will continue to operate East and West in the same independent manner as they have heretofore operated, reserving to themselves the right to retain their present eastern machinery for distribution and their present western machinery for securing and making shipments, it being further understood that the proposed advisory council will arrange schedules and quotas of distribution that as nearly as possible will be just and equitable to the adherents and that the fruit will be routed and diverted in a manner to respect as far as possible the preferences of the owner of such fruit.227

From this outline it is apparent that Weinstock did not plan to go further than to establish a clearing house. This interpretation is strengthened also by another explanation given by Weinstock at a later date, which was: "This Bureau, by agreement among the adherents, would be daily supplied with the fullest information with regard to the movement of every car of citrus fruits and it would avert glutting the markets through its ability to advise shippers when and where to divert cars to their own advantage. It would not have arbitrary control over the shipments, but would act merely in an advisory capacity, carefully respecting preferences for certain markets." ${ }^{228}$

Although the Fruit Growers' Convention recommended that the industry adopt the plan, Weinstock did not succeed in obtaining the support of the California Fruit Growers' Exchange nor was he able to

227 Forty-eighth Fruit Growers' Convention, Proceedings. p. 71. February, 1916.

228 California Fruit News 54(1466):9. 1916. 
win over the California Fruit Exchange when he proposed a similar plan to the fresh-deciduous-fruit industry. Independent shippers of fresh deciduous fruits, controlling about 85 per cent of the fruit sent out of the state, were said to be willing to join the proposed State Bureau of Distribution, but the California Fruit Exchange refused to come in. It fought the plan on the basis of the following four main objections: (1) It was said that there was danger of political influence on the distribution of fruit; (2) the fear was expressed that market information might become public to the benefit of the eastern speculative buyers $;^{229}$ (3) it was argued that the State Commission Marketing Act does not give the State Market Director any authority for regulating the marketing of fruit beyond the state lines; and (4) it was stated that the danger of violating anti-trust laws was not eliminated by making the state establish and supervise the distributive organization.

Another thing which prevented Weinstock from carrying his plan into effect was the resentment which developed when he tried to stir up antagonism against the decisions of cooperative marketing leaders who had refused to accept it. ${ }^{230}$

\section{BEGINNINGS OF THE POST-WAR CLEARING-HOUSE MOVEMENT}

Toward the end of 1923, a new clearing-house movement started in the California fresh-deciduous-fruit industry. This movement first manifested itself in an attempt to set up a clearing house for table grapes, and in the expression of hopes that after satisfactory results had been achieved similar organizations would be established for other fruits. A conference of marketing agencies held in San Francisco in December, $1923,{ }^{231}$ recommended the formation of a clearing house for table grapes. The proposal was supported by representatives of the federal government whose advice and assistance was sought. But in spite of long negotiations and great efforts to sign up the distributing agencies, no clearing house for the handling of table grapes was established.

229 The General Manager of the California Fruit Exchange at the Fruit Growers' Convention at Napa held in November, 1916, said: "Why should our growers, after spending sixteen years of hard labor and thousands of dollars a year in accumulating the intelligent information, turn this information over to the state where it may be hung upon a public file and thereby invite and create eastern competition-a competition that has spelled disaster to the industry and has proven to be a parasite." California State Commissioner of Horticulture, Mo. Bul. 6:169. 1917.

230 Forty-ninth Fruit Growers' Convention, Proceedings. p. 170-172. 1917.

231 This conference convened at the invitation of Ralph P. Merritt, of the SunMaid Raisin Growers' Association. Merritt hoped to divert a portion of the raisin crop into the table-grape market by improving the marketing conditions for table grapes. (California Fruit News 69[1852]:1. January 5, 1924.) The clearing-house plan was, as a matter of fact, suggested in June, 1923. (See editorial: Deciduous shipments need re-establishment of clearing house. California Fruit News 67 [1823]:3. June 16, 1923.) 
In the opinion of J. E. Bergtholdt, of the Silva-Bergtholdt Company at Newcastle, who spoke on the subject of clearing houses at the Fourth Annual Placer County Fruit Growers' Convention held in October, 1924, the attempt failed because too many shippers refused to give up their individual rights of determining the routings of all their shipments as required in the proposal. Instead of asking for so much control, Bergtholdt proposed that clearing houses should be entrusted with only the following tasks: (1) to keep records of daily routings, diversions, and dates of arrival of cars; (2) to render to each affiliated shipper daily reports on all such routings, diversions, and scheduled daily arrivals at the various auction markets including the Omaha gateway; and (3) to correct distribution to the degree that would assure a regularity of supplies to all markets according to their capacity. ${ }^{232}$

Although a new committee was formed for the purpose of continuing the organizational efforts, no definite action was taken. Therefore, the 1925 marketing season also passed without any clearing house operations. But in the following year two important events carried the movement forward.

One event was the establishment of an informal clearing house for table grapes near the end of the 1926 marketing season. In this enterprise the California Fruit Distributors, the California Fruit Exchange, the American Fruit Growers, and the F. H. Buck Company participated. Since, in the opinion of the members, some good results were achieved, the sentiment for a continuation of previous efforts to set up clearing houses became stronger.

The other event was the establishment of the California Vineyardists Association. This organization grew out of the Grape Car Plan developed by the American Railway Association for the 1926 marketing season and was formed at a meeting of representatives of grape growers held in October of that year at Fresno. ${ }^{233}$ The California Vineyardists Association was incorporated as a nonprofit, nonstock association. ${ }^{234} \mathrm{It}$ was not to be a marketing association, but rather a service organization for the entire grape industry. Although it was rather a loosely organized association, having no contracts with grower and having no capital, it offered a means of bringing shippers together for joint action such as for

232 Fourth Annual Placer County Fruit Growers' Convention, Proceedings. p. 68. 1924.

233 Kieffer, D. I. A shipping grape association at last. Pacific Rural Press 112:473. 1926. Also: California Produce News $29(39): 1.1926$. A preliminary ineeting had been held at Lodi at which an organization committee was chosen of which P. A. 'Towne was made chairman. California Fruit News 74(1929):3. October 30, 1926.

2:34 California Wruit Nows 74(2002):7. November 20, 1926. 
clearing-house operations without fear of violation of anti-trust laws. It was expected to take measures to improve transportation conditions; to foster the orderly distribution of California grapes; to obtain favorable legislation; and to promote the welfare of the grape growers in all other possible ways.

\section{CLEARING HOUSES FOR GRAPES}

In line with its task of fostering the orderly distribution of grapes the California Vineyardists Association immediately started to promote the establishment of a clearing house for grapes. Subsequently, the Board of Directors of the organization appointed a committee of seventeen for the purpose of working out the details of the set-up. This committee, it was decided, should comprise not only representatives of the various shipping agencies, but also a representative of the United States Department of Agriculture, a representative of the United States Department of Commerce, and a representative of the California State Department of Agriculture.

The plan which the committee of seventeen recommended was along the following lines: The clearing house should be conducted by a managing committee which was to act under the supervision and direction of the Board of Directors of the California Vineyardists Association. This managing committee should consist of seven active and four advisory members. The seven active members were to include six representatives of the shipping agencies affiliated with the clearing house and a chairman to be selected by the California Vineyardists Association. Furthermore, it was proposed that in each of the eight districts of the California Vineyardists Association, district clearing-house committees should be formed which were to carry out the instructions of the executive committee and, in addition, to support the proper operation of the central office in any other possible way. Furthermore, it was recommended that a contractual relation should be created between the California Vineyardists Association and the shippers, and that the clearing-house charges should be levied on a carload basis.

This plan was adopted with very few modifications. The contract which was subsequently drawn up in collaboration with the United States Department of Agriculture and the California State Department of Agriculture contained the following main points: ${ }^{235}$ The shippers agreed to supply the clearing house with a certain amount of market information. This information was to be collected and compiled by a representative of the United States Department of Agriculture. Further-

235 California Vineyardists Assoc. Bul. 1(3):․ 1927. 
more, the government agency of the clearing house was authorized to examine, if considered necessary, the records of shippers for the purpose of perfecting the collection of information. The shippers also consented to collect a fee of 25 cents per net ton of all grapes purchased, handled, or shipped from the growers and to turn it over to the clearing house. They likewise agreed to abide by the recommendations of the clearing house. On the other hand, the California Vineyardists Association promised to furnish daily reports on marketing conditions to the members of the organization and to advise them in their marketing policy. The California Vineyardists Association also pledged itself to urge its grower members to market their fruit only through shipping agencies which belonged to the clearing house. In addition, it was provided that the agreement should be in effect for three years with the possibility of withdrawing annually between December 16 and 31 .

This clearing house was of the information type. To attempt to make it anything more was considered inadvisable since the shippers and growers were unwilling to sign any contract which would give the clearing house the power of enforcing its recommendations and of imposing fines in cases of violation.

In the course of the 1927 marketing season about 300 shippers, or about one-half of the shipping agencies engaged in the marketing of California grapes, joined the enterprise. However, those who joined the clearing house controlled about 75 to 80 per cent of the grape tonnage. During the same period the membership of the California Vineyardists Association rose to about 8,500 grape growers.

In its first year of operation the clearing house did little more than experimental work. It endeavored to cut down the volume of grape shipments whenever eastern markets threatened to become oversupplied. Its recommendations included the proposal of stopping the loadings for several days. ${ }^{236}$ But, since the California Vineyardists Association had no authority to enforce its recommendations, and since a large number of the shipping agencies had remained on the outside, only moderate results were achieved. ${ }^{237}$

Although it was recommended at the end of the 1927 marketing season that a more binding contract be adopted for the following marketing season, no such steps were undertaken. An attempt was made to improve the set-up along the lines of the following recommendations made by the executive committee of the clearing house in April, 1928 :

236 California Vineyardists Assoc. Bul. 1(9):1. 1927. Pacific Rural Press 114: 368. 1927.

237 California Vineyardists Assoc. Bul. 1(10):4. 1927. 
(1) All shipper members of the clearing house will pay a charge of 50 cents per car (and will collect 25 cents per ton from the grower) as their contribution to the expenses of the Association. This charge will be regarded as an associate membership fee on the part of the shipper. (2) Shippers will permit the manager of the clearing house to review all car loadings and distribution records of the Departments of Agriculture and of the railroads. (3) Shippers will report daily loadings at all stations to the Association. (4) Members of the clearing house will include in their written contracts with growers a provision calling attention to the charge of 25 cents per ton which the Association requests its members to contribute for the support of its general program of activities. Shippers' contracts will also include the provision that the acceptance and delivery of grapes shall be subject to the recommendations of the Clearing House Division of the California Vineyardists Association. (5) District clearing house committees will be established this year at Ukiah, Santa Rosa, Napa, Lodi (with subcommittee on American River), Modesto (subcommittee at Turlock, Fresno, Exeter, and Ontario.238

The results of clearing-house operations in 1928 were again very unsatisfactory. The following statement of the Managing Director to the Board of Directors of the California Vineyardists Association pictures the results :

The Clearing House agreement became a "scrap of paper" in 1928 because many who joined in the first instance never intended from the outset to carry out its obligations, and intentionally violated its recommendations. Others were "slippery" in their relations to the Association. No few shippers accumulated their profits by the process of underweights in violation of Federal laws. Too many are entrusted with the obligations of a "public weigh master." That unlawful practices, known among those intimately acquainted with the industry, have been permitted, or allowed to continue unchallenged by both State and Federal Governments, represents a sad commentary upon enforcement agencies. Responsible shippers cannot stabilize marketing conditions when confronted with competition from such factors. In spite of the existence of these conditions, growers actually continue to patronize irresponsible shippers notwithstanding previous experiences and warnings. As a whole, the marketing of juice grapes presents the most aggravated picture of chaos and irresponsibility surrounding the distribution of any commodity in America.239

Although difficult to prove statistically, ${ }^{240}$ it was generally conceded that the clearing house did not succeed in avoiding the glutting of juice-grape markets. Since the reason for the failure of the clearing house operations in 1927 and 1928 lay mainly in the lack of authority of the clearing house to enforce its recommendations, it was subsequently decided to modify the set-up for $1929 .{ }^{241}$ On the one hand, the relation

238 California Vineyardists Assoc. Bul. 2(4):2. 1928.

239 California Vineyardists Assoc. Bul. 3(1):2. 1929.

240 For an analysis of the relation of weekly shipments of California black juice grapes in relation to weekly sales for the seasons 1925-1928, see: Mallory, L. D., S. R. Smith, and S. W. Shear. Factors affecting annual prices of California fresh grapes, 1921-1929. Hilgardia 6:114-120. 1931.

241 California Vineyardists Assoc. Bul. 2(3):6. 1929. 
of the California Vineyardists Association with its growers was to be strengthened by a contract providing among other things that growers market their crop only through shippers who had entered into contractual relations with the California Vineyardists Association as members of the clearing house, a provision which had already been urged in $1928 .{ }^{242}$ On the other hand, a new clearing-house contract was submitted to the shipping agencies which obligated the latter to follow the recommendations of the California Vineyardists Association under a penalty of $\$ 100$ a car for each case of violation. The contract with the shippers also stipulated that the clearing house should have a definite control of all the distribution of table varieties, the volume of juice grapes loaded, standardization, and other important marketing factors. $^{243}$ In other words, the clearing house was to be given regulatory powers.

Although the 1929 grape crop was relatively a short one, the summer was a hectic one from the point of view of the grape growers. A special session of Congress was considering the passage of farm relief legislation which was apparently to provide for a Federal Farm Board. The new contracts above mentioned, both with growers and with shippers, had not been signed in any large numbers before the Federal Grape Stabilization Corporation was formed in anticipation that it would fit into the provisions of the Agricultural Marketing Act when the latter became a law. ${ }^{244}$

The Stabilization Corporation, ${ }^{245}$ incorporated on May 7,1929 , as a

242 California Vineyardists Assoc. Bul. 2(1):2. 1928. Previous to 1929 the grower had not been required to sign a contract.

243 For a general statement on the set-up of the clearing house, see: Stillwell, E. W. Clearing house organization of shipping agencies for 1929. California Grower 1(3):5. 1929.

244 California Vineyardists Assoc. Bul. 2(4):1-2. 1929. Also: Conn, D. D. The Farm Relief Act. California Grower 1(1):3-5. 1929.

245 The original directors were: Donald D. Conn, Managing Director, Associated California Fruit Industries, Inc. and California Vineyardists Association; Harry M. Creech, President, Sun-Maid Raisin Association and Sunland Sales, both cooperative, Fresno; Scott F. Enmis, President, Pacific Fruit Exchange, San Francisco; Roland D. Fontana, Di Giorgio Farms, largest grape grower in California, San Francisco; H. R. Freeland, large grape grower, San Joaquin Finance Corporation, Fresno; Joseph T. Grace, large grower, President of Grace Bros., Santa Rosa; T.T. C. Gregory, Attorney at Law and General Counsel, Associated California Fruit Industries, Inc., San Francsico; R. E. Hyde, large grower, Visalia; Walter Jahant, large grower, Lodi; J. M. Leslie, President, Sun-Maid Raisin Growers of California, Fresno; Walton N. Moore, large grower and President of Walton N. Moore Co., San Francisco; J. L. Nagle, General Manager, California Fruit Exchange, a cooperative, Sacramento; Lucius Powers, large grower, owner of Lucius Powers Fruit Co., Fresno; R. J. Senior, Chairman Agricultural Committee, Fresno County Chamber of Commerce, Fresno; Paul Shoup, President, Southern Pacific Company, San Francisco; Lloyd S. Tenny, President, Federal Grape Stabilization Corporation, San Francisco; A. Emory Wishon, large grower and General Manager, Great Western Power Company, San Francisco. California Grower 1(1):5. 1929. 
membership organization, was to: "(1) Furnish funds for production and harvesting; (2) buy and sell grapes and raisins; (3) build or rent plants and machinery for by-products; (4) do everything else necessary to direct and control marketing of grapes and deciduous crops." ${ }^{246}$

There was to be a purchase contract under which the Stabilization Corporation would agree to buy all raisin grapes for a period of three years at stated prices. On the basis of such contracts the Stabilization Corporation would borrow of the proposed Federal Farm Board. The contracts circulated among producers of fresh grapes did not provide for purchase of grapes but did provide for the purchase by the growers of "participation certificates" at the rate of from 2 to 5 cents per package of fresh grapes (depending upon type of grape and package), the proceeds to build a fund for purchasing surpluses.

With the completion of the plans for the Stabilization Corporation, its contracts and those of the California Vineyardists Association were simultaneously circulated for signatures. As a matter of fact, there was so much confusion in the minds of the growers that the whole program had to be given up because sufficient signatures could not be obtained.

In the meantime, the Federal Farm Board and a group of California bankers late in August, 1929, arranged to lend a large sum of money to the Sun-Maid Raisin Growers to provide for a 3-cent advance a pound on Muscats and Thompson Seedless to growers who belonged to or pooled with Sun-Maid. A few weeks later the Stabilization Corporation, in order to divert raisin grapes from fresh-grape markets, announced that it would pay a bonus of an extra cent a pound on Muscat raisins in 1929. After many growers had dried their grapes, and it was too late to make fresh shipments, the Stabilization Corporation announced that it would not have money to pay the bonus. ${ }^{247}$

Late in the summer another corporation, Fruit Industries, Inc., was formed to take care of by-products, also in anticipation that the whole scheme would fit into the program of the Federal Farm Board from which funds were to be obtained. ${ }^{248}$ The organization included a group of the larger California manufacturers of grape juice, wines, and other grape products, and was to develop an enormous by-product business as part of its stabilization program. ${ }^{249}$

246 California Vineyardists Assoc. Bul. 2(4):1. 1929.

247 See footnote in: Mallory, L. D., S. R. Smith, and S. W. Shear. Factors affecting annual prices of California fresh grapes, 1921-1929. Hilgardia 6:127. 1931.

248 Conn, Donald D. The Farm Relief Act. California Grower 1(1):3-5. 1929. Also: Tenny, Lloyd S. Program of the Federal Fruit Stabilization Corporation. California Grower 1(2):30-31. 1929.

249 Conn, Donald D. Better prices will be reflected in industry control. Cali. fornia Grower 1(2):3-4. 1929. Also an advertisement: California Grower 1(2):9. 1929. San Francisco Chronicle 134(167):3. July 1, 1929. 
The appeals to the Federal Farm Board for financial assistance in the fall of $1929^{250}$ resulted, in the summer of 1930 , in the establishment of the California Grape Control Board. The latter was composed of the California Raisin Pool (represented by 10 directors), the California Fruit Exchange (with 3 directors), the California Vineyardists Association (3 directors), the San Joaquin Grower-Shipper Association (2 directors), Fruit Industries, Ine. (2 directors), and a director representing the Federal Farm Board. The California Raisin Pool had been set up to include both the Sun-Maid Raisin Growers Association and independent raisin growers. The San Joaquin Grower-Shipper Association was established to include a group of fresh-grape growers who would not affiliate with the California Fruit Exchange, nor with agencies under contract with the California Vineyardists Association. ${ }^{251}$

During the development of plans for the Grape Control Board, discussion had centered around control of the surplus, which was roughly estimated at 300,000 tons of fresh grapes of all varieties in an average year. The plan called for the deduction of $\$ 1.50$ a ton from returns on all grapes shipped by any of the affiliated agencies and $\$ 5.25$ a ton on raisins. It was estimated that the resulting fund would make possible the purchase on the vine of sufficient grapes to maintain prices at profitable levels. The required 85 per cent of the tonnage was not signed up until late in July. ${ }^{252}$

The Grape Control contract itself did not mention clearing houses. Hence many growers and shippers had assumed that there would be no restriction on shipments. ${ }^{253}$ However, the Board set up a committee to take over the operation of the clearing house previously carried on by the California Vineyardists Association. This committee consisted of seven men representing the three fresh-grape organizations, the

250 Congressional Record 71(125):6229. November 22, 1929.

251 The San Joaquin Grower-Shipper Association was organized in June, 1930. (See articles in: Fresno Republican, June 18, 20, and 26, 1930.) Provision to make it a part of the Grape Control Board was made by action of the Board of Directors of the latter on July 18, 1930. At the same time the representation of the California Raisin Pool on the Grape Control Board was increased from 8 to 10 to preserve "the balance of representation between the dried and fresh-fruit elements of the industry." (See: Grape Control Board swings into action. Fresno Republican, July 19, 1930.) For the general plan and a copy of the grower contract see: "The Federal Farm Board Program for Rebuilding California's Grape Industry." Pamphlet issued by Federal Farm Board, spring of 1930 (undated).

252 Success of the campaign was announced at Fresno on the evening of July 25. (Fresno Republican, July 26, 1930.) The sign-up report was accepted by the Farm Board on July 29. (Fresno Republican, July 30, 1930.) The report placed the tonnage under control at 88 per cent and the acreage at 85 per cent.

253 See: Shippers balk at program; control may fail for year. Fresno Republican, August 3, 1930 . 
California Vineyardists Association, the California Fruit Exchange, and the San Joaquin Grower-Shipper Association. ${ }^{254}$

Unfortunately the clearing house committee of the Grape Control Board did not have power to enforce its recommendations. So far as the contract of the California Vineyardists Association with its member shippers was concerned, it was similar to that used for the 1929 marketing season which included provisions for enforcement. The contract between the San Joaquin Grower-Shipper Association and its members was less tightly drawn. Furthermore, no special clearing-house agreement was established between the California Fruit Exchange and its members. There was, therefore, a great lack of uniformity in the contracts.

The results of the operations during the 1930 marketing season are given in the following statement from the report of the Grape Control Board to the Federal Farm Board submitted in January, 1931:

In spite of weaknesses in the set-up, recommendations made by the clearing house committee met with satisfactory response up to the first of October. This performance placed the industry in a very favorable statistical market situation. The number of cars of grapes en route to market and held on tracks in the eastern markets the first week in October was appreciably less than in any recent year. The result was that in spite of low buying power, a dull market in September was turned into one embracing good demand and increased prices during the early part of October.

This, the first real market activities in 1930, created an irresistible urge on the part of both growers and shippers to load grapes and send them to market. It constituted an effort to salvage something out of the crop and, in many cases, to return losses suffered under the low price levels in the early part of the season. The machinery for regulating shipments failed to function. Available carload supplies increased beyond any reasonable bounds and the favorable situation of early October became by late October most unfavorable. Prices declined to disastrous levels. Especially heavy losses were suffered by both growers and shippers. 255

Reasons for the Breaking Down of Clearing-House Operations.-In looking for the reasons for the breakdown of clearing-house operations in 1930, one may say that the following defects in the set-up were mainly responsible: (1) No plan for restricting shipments on some systematic basis was worked out in advance; (2) the contractual relation between the Grape Control Board and the three affiliated fresh-grape agencies did not grant any power to enforce the recommendations of the Grape Control Board in regard to restriction of shipments, and did not provide a penalty for failure to comply; (3) differences in the contracts of the three agencies with their members prevented a uniform application of clearing-house recommendations; and (4) deficiencies in the organiza-

254 Fresno Republican, August 17 and 19, 1930.

255 Mimeographed report dated January 14, 1931. 
tion of district committees made ineffective the work of the central clearing-house committee.

There were, of course, a large number of other factors which tended to prevent the effectiveness of clearing-house operations. The quantity of grapes was so large that not as much could be done by restricted shipments as had been expected. Again, the number of shippers was so large as to make control difficult. As usual there was jealousy and distrust between the various groups, and much misunderstanding of the whole plan. The latter could hardly have been avoided under the circumstances. The plan as finally adopted was in process of development until the shipping was actually under way some two months after the sign-up campaign had begun. ${ }^{256}$

On the basis of this experience it was proposed to improve the contractual relations as well as other conditions. Recommendations were made to make the contracts more binding; to do away with the differences in the contracts of the marketing agencies with their members; to authorize the restrictions of shipments of low-grade grapes; and to improve the collaboration with the railroads.

The suggested improvements in the contractual relations met serious opposition. Furthermore, the 1931 crop proved to be a light one. Hence the Grape Control Board continued its clearing house during the 1931 marketing season without the proposed regulatory features.

\section{CLEARING HOUSES FOR FRESH DECIDUOUS-TREE FRUITS}

When the California Vineyardists Association was organized in the fall of 1926, its leaders considered for a time the organization of a clearing house for deciduous-tree fruits as well as for grapes. It was decided to concentrate all efforts on the formation and operation of a grape clearing house. However, a futile attempt was made at the beginning of 1927 to set up a clearing house for deciduous-tree fruits.

Early in 1928, the California Vineyardists Association joined the movement for the establishment of a clearing house for deciduous-tree fruits, since its leaders saw that it could advantageously combine the operations of such a clearing house with those of its own. It helped to organize a service organization for the deciduous-tree-fruit growers, which was first called California Deciduous Fruit Association, ${ }^{257}$ and later Associated California Fruit Industries, Inc. This organization was

256 Koster, F. J. The work of the California Grape Control Board, Ltd. California Grower 3(1):5. 1931.

257 Incorporated January 20, 1928, on a plan similar to that of the California Vineyardists Association. Membership fees were $\$ 1.00$, annual dues $\$ 1.00$ and a contribution of $\$ 0.25$ a ton was to support its activities. California Vineyardists Assoc. Bul. 2(2):2. 1928. 
not to build up a special clearing-house division, but was to avail itself of the services of the clearing-house staff of the California Vineyardists Association and share in the expenses for the common personnel. It was pointed out that such a combination would make it possible to maintain an all-year-round clearing-house staff for both organizations at a reasonable cost, whereas in case of separate operations the maintenance of the personnel throughout the year might become too expensive because of the seasonal character of the business.

This proposal was accepted. A close relation was created between the California Vineyardists Association and the California Deciduous Fruit Association by means of the provision that six of the eleven members of the Board of Directors of the latter association should be chosen out of the Board of Directors of the California Vineyardists Association. ${ }^{258}$ This relation was further strengthened by the decision that Managing Director Donald D. Conn, of the California Vineyardists Association, should also become managing director of the new organization.

The first clearing-house contract of the California Deciduous Fruit Association, with its affiliated shipping agencies, was very similar to that of the first clearing-house contract of the California Vineyardists Association. Accordingly, the deciduous-tree-fruit clearing house functioned as an information clearing house in the 1928 marketing season. In 1929 the California Vineyardists Association decided to strengthen its clearing house for regulatory purposes, but the California Deciduous Fruit Association took no such action.

In the course of 1929, differences of opinion developed between the California Fruit Exchange and the California Vineyardists Association which led to the complete separation of the clearing-house work of the two groups. During the 1930 marketing season, the clearing house of the Associated California Fruit Industries, Inc., was, therefore, operated separately under the management of Wilmer Sieg. In the following year, however, the Associated California Fruit Industries, Inc., clearing house was not maintained. Instead, an informal arrangement was perfected whereby, in collaboration with the United States Department of Agriculture and the California State Department of Agriculture, a number of shipping agencies engaged in the marketing of fresh deciduous-tree fruits received certain marketing information from the representative of the United States Department of Agriculture in San Francisco and contributed to the cost of this service. An informal clearing house was also operated by shippers interested in the distribution of cherries and figs to auction markets. ${ }^{259}$

258 California Vineyardists Assoc. Bul. 2(2):2. 1928.

259 Statement by E. W. Stillwell, November 29, 1932. 


\section{GROWER-DEALER ORGANIZATIONS IN THE WATSONVILLE REGION}

Perhaps because cooperative marketing has made little headway, industry cooperation has repeatedly been urged in the Watsonville apple district. Several grower-dealer organizations have been formed in this area during the past two decades. The first was established in 1915; the second in 1924; the third in 1927; and the fourth in 1931.

Watsonville Apple Distributors.-In June, 1915, a group of growers, packers, brokers, bankers, and merchants organized the Watsonville Apple Distributors. The organization was to standardize the pack, arrange for inspection of the fruit, establish minimum prices, and promulgate rules for storage and consignment operations. It adopted the California Standard Apple Act of 1915 as a basis for its standardization regulations.

The direction of the organization was placed in the hands of an executive committee of twenty-one. This committee appointed a Board of Control of five members which handled all complaints and acted as advisor to the California State Commissioner of Agriculture.

In the first year of its existence, the organization made great efforts to advance the standardization and inspection work. It sold its own inspection stamps, handled the state stamps, and contributed in a considerable measure to the success of its inspection program under which 75 per cent of the 3,000 cars shipped in the 1915 season were inspected. It endeavored to stop the shipment of immature apples and was instrumental in bringing about ordinances in Santa Clara and Monterey counties which prohibited such practices. Moreover, it undertook to establish and maintain minimum prices and endeavored to achieve reductions in freight rates.

At the end of the year the organization had 505 members, consisting of 249 growers, 32 packers, 12 brokers, and 212 other business men. As there was a feeling that the work of the organization should be enlarged and strengthened, particularly in the direction of marketing, a mass meeting of orchardists, packers, and other persons interested in the industry was held in Watsonville in April, 1916. At that meeting State Market Director Weinstock and Vice-President and General Manager Madison of the California Raisin Growers made addresses in which they recommended taking further organizational measures which Weinstock promised to support with the help of his office.

As a result of this meeting, a committee of nine was appointed to draw up a plan for the establishment of a central sales agency. This com- 
mittee, which later enlarged its membership to thirty-one, submitted its findings to the first annual meeting of the Watsonville Apple Distributors in June, 1916. It proposed to change the Watsonville Apple Distributors into a capital-stock corporation and to make it a central marketing agency which should be well financed and should control a large proportion of the total crop. In order to achieve this control the committee deemed grower-packer cooperation essential.

The capital stock was fixed at $\$ 125,000$, divided into shares of par value of $\$ 10$ each. To this stock the growers were expected to subscribe on the basis of one share per acre of bearing apple trees. The packers were expected to purchase stock at the rate of 4 cents per packed box of apples which, it was estimated, would correspond very closely with the acreage basis for growers. In addition, business men were allowed to subscribe for stock, if they so desired, but not in excess of 25 per cent of the total amount of shares in order to keep the control of the enterprise in the hands of those directly engaged in the apple business. Apart from this restriction on the sale of stock to business men, a special provision was made for the purpose of maintaining the control in the hands of the growers and packers and preventing it from passing into the hands of persons whose interests might become antagonistic to those of the growers and packers. According to this provision all the stock was to be pooled for four years and turned over to a Board of Trustees to be selected by the stockholders.

In order to assure the control of the crop, the growers and packers were expected to sign an agreement according to which they would either market their fruit directly through the organization or in some other way which would give the organization control. Thus direct selling was to be permitted because it was foreseen that a large number of the important packers would be unwilling to give up their established markets and selling facilities immediately. But the organization was to bill out the cars and collect the money on such direct sales. The agreement was to bind the growers and packers for a period of four seasons. Furthermore, it was to be safeguarded against violation by giving the organization full power to take possession of the fruit and to collect all necessary information.

The organization was not to become effective until at least 90 per cent of the average crop of apples produced in the Watsonville area, estimated at 2,000,000 packed boxes, was signed up. The Watsonville area was described as the territory within a radius of 10 miles from the center of the city of Watsonville. 
The proposed organization was to market fruit for its stockholders; to buy and sell on its owl account; to engage in the purchase of supplies such as box shook, paper, and spray materials; and to make advances to its members in order to assist them in the growing, hauling, and packing of their fruit. It was to have the power of fixing the price from time to time. And it was to build up an advertising fund by deducting a certain amount from the returns on all fruit sold or cleared through the association in order to widen the market for the apples of the Watsonville area.

The plan was approved at the meeting of the Watsonville Apple Distributors. The by-laws were adopted and the officers for the first term elected. But it was not possible to sign up the required 90 per cent of the acreage. In the meantime, prices of apples rose in 1916 and the following years along with other prices. With improved returns the idea of organization lost in favor and the movement was discontinued.

The Second Joint Marketing Organization.-About eight years later, in 1924, a new movement for the organization of the apple industry developed in the Pajaro Valley, following a decline in prices in 1922 and 1923 and the accompanying dissatisfaction with marketing conditions.

Mr. J. E. Gardner, a Watsonville attorney, who had assisted in the establishment of several cooperative marketing associations and who had also participated in the drafting of the plan for the joint marketing organization proposed in 1916, was again asked to lend his support and to undertake a study of a number of cooperative organizations in California and the Northwest in order to find out whether some of their features of organization and operation might be advantageously used in the Watsonville area. As a result of this study a plan was worked out which was based largely on that of the Sun-Maid Raisin Growers.

The plan provided for the establishment of a nonprofit, nonstock association to be incorporated under the Cooperative Marketing Act of 1923, and the creation of a subsidiary warehouse corporation which should be incorporated under the laws of the State of Maryland or Delaware. This subsidiary was to have common and preferred stock. The common stock was to be taken over by members of the parent organization, whereas the preferred was to be sold to outsiders interested as investors.

The association, like its proposed predecessor, was to be a joint marketing organization of growers and packers. 'The name chosen was the same, Watsonville Apple Distributors. The provisions for operation were similar to those of 1916 in that they were to disturb existing con- 
ditions as little as possible and to utilize existing equipment to the full extent.

There were, however, a number of differences in the two plans. One of them, already mentioned, was the provision that the association should have no capital stock. Another difference was that the contract period should extend over seven years. Instead of making the effectiveness of the plan dependent on the sign-up of 90 per cent of the total production the desired minimum control was fixed at 75 per cent. Furthermore, the area was enlarged to include a territory with a radius of 15 miles.

After the plan had been submitted to a mass meeting held in April, $1924,{ }^{260}$ a membership drive was undertaken. This campaign did not result in the required number of signatures. There was much opposition to the idea of a seven-year contract, and the owners of large orchards objected to the one-man-one-vote provision, which had been included in the plan of organization. A number of changes were therefore made in the constitution and by-laws, largely in the interests of the packers. Finally, however, the required acreage was signed up and the organization was launched. ${ }^{261}$

The organization functioned for two seasons. It announced minimum prices and tried to regulate shipments. Weekly meetings were held during the shipping season, and, if necessary, cars were prorated in order to prevent market gluts. As a result of dissatisfaction among the members the agency was discontinued in 1926.

Watsonville Apple Growers' and Packers' Association.-Since the need for organization remained, a third joint marketing organization was formed in February, 1927. This organization, called the Watsonville Apple Growers' and Packers' Association, was established largely along the lines followed in the final set-up of the agency of 1924. A one-year marketing agreement had to be signed; its membership consisted mainly of packers and packing associations; and the territory was extended to a region within a radius of 50 miles from Watsonville.

The organization operated for four seasons. It sold for its members, endeavored to regulate shipments, and sought to increase the sale of Pajaro Valley apples through advertising. Pooling was not practiced. In order to cover its expenses, the association deducted 1 cent a box from the sales receipts. Any surplus remaining after expenses had been paid was refunded to the members.

260 Newman, Ralph. Watsonville seeks "one way out." Pacific Rural Press 107: 613. 1924.

261 California Produce News 27(36):1. September 6, 1924. Pacific Rural Press 108:234. 1924. 
It has been estimated that the enterprise controlled about 75 per cent of the shipments in the first marketing season and about 40 per cent in the 1930 season. The Loma Fruit Company joined the organization in 1927, but later withdrew. The Corralitos association belonged to it during the four seasons in which it was active. At the beginning, there were about 50 members, and at the end, about 20 . The reason for the decline in membership and volume of business is that too much suspicion, distrust, and individualistic feeling existed among the packers themselves on the one hand, and between the packers and growers on the other.

Watsonville Apple Selling Organization.-A special pooling arrangement was made in March, 1931, and carried out under the above name. Not only members of the Watsonville Apple Growers' and Packers' Association, but also nonmembers participated in it. The arrangement was proposed at a time when a large quantity of apples, primarily Yellow Newtowns, had accumulated in cold storage in Watsonville and when it seemed inevitable that severe losses would occur if these apples were sold in a disorderly way on the prevailing depressed apple market. The pooling agreement became effective upon the sign-up of holders of 90 per cent of the loose (unpacked) Yellow Bellflowers and Yellow Newtowns in Watsonville storage. Two separate pools were formed: one for Yellow Bellflowers, and another for Yellow Newtowns. Furthermore, it was provided that the marketing should be done by an executive committee consisting of five members. This committee was given title to all the stored apples and empowered to sell them at prices which it deemed best. It prorated the sales among the members of the pools in proportion to the number of boxes owned by them. It retained a certain amount from the sales receipts in order to cover expenses and to build up a sinking fund out of which price adjustments were made at the end of the pooling period.

The pooling operations lasted until July 1, 1931. At the time pooling operations were started, the market price for Yellow Newtowns was $\$ 30$ a ton. This price was gradually raised to about $\$ 37$. Altogether, 265,779 boxes were sold of which about 260,000 were Yellow Newtowns. Despite this example of better results through joint marketing, no steps were taken to continue the operation of the Watsonville Apple Growers' and Packers' Association for the 1931 season.

Pajaro Valley Fruit Association.-As a reaction to the repeated failures in attempts to build up an efficient marketing structure on a large scale, another small combination was effected at the beginning of the 1931 season. This organization intends to follow a policy of selective 
membership and to strive towards the orderly distribution of the highgrade apples produced in the Pajaro Valley. Its leaders hope thereby to improve the reputation of the apple industry in the Valley, for this reputation has suffered to a considerable degree during the last few years because of unreliable packs. It consists of the Loma Fruit Company, the Corralitos Fruit Growers Incorporated, T. J. Horgan \& Company, and Rodgers Brothers.

\section{GROWER-DEALER ORGANIZATIONS IN THE SEBASTOPOL REGION}

Gravenstein Growers and Packers.-In the Sebastopol region the first movement for the establishment of a joint organization of cooperative growers and independent packers occurred in 1925. The desire to increase the sale of the Gravenstein apples by means of an intensive advertising campaign over the entire United States to which all the various interests of the industry should contribute was the main idea in the minds of the promoters. Other ideas added later were orderly distribution of the product and improvements in grading.

The movement attracted support not only in the Sebastopol region but in the Sonoma region and Napa County as well. At the organization meeting held in April, 1925, it was found that agencies handling over 95 per cent of the tonnage of Gravensteins grown in Sonoma and Napa counties were inclined to join the new enterprise which was to be called the "Gravenstein Growers and Packers." 262

An ambitious program was immediately adopted. It consisted of 14 recommendations which were:

1. To secure widest possible distribution.

2. To avoid market gluts and famines.

3. To hold back shipments at peak periods.

4. To market only reputable products.

5. To sell wholesale to jobbing trade.

6. To do educational work with the trade.

7. To secure and put to effective common use complete daily market information as to movement of products and conditions of all markets.

8. To establish grades and standards and improve packing methods.

9. To establish brands to facilitate national advertising and collectively to put on national advertising campaigns.

10. To develop by-products out of lower grades: first, to salvage waste; second, to save glutting markets in periods of overproduction.

262 The following persons were entrusted with the management of the organization: J. P. MeDonnell, of the Sebastopol Apple Growers' Union, president; J. M. Garcia, of the Garbro Fruit Co., vice-president; George Burlingame, of the Sebastopol Chamber of Commerce, secretary; and J. R. Durbin, of the Gravenstein Apple Growers' Cooperative Association, treasurer. Clipping from Santa Rosa Press Democrat. April 14, 1925. 
11. To purehase collectively the major supplies entering into the processes of growing and preparing for market.

12. To study the methods of the shippers, to increase efficieney, climinate waste, and lower costs.

13. To gather statisties as to cost and trend of production and consumption, so that all interests may be informed and thus avoid disastrous periods of overproduction, or to increase production as conditions warrant.

14. To handle national industrial problems such as: Freight and traffic questions : tariff representations before Congress; legislation, state and national, affecting the industry.263

The organization existed for about two years. It took a few actions but it did not accomplish anything of importance along the lines mentioned in the program. A short crop in 1925 resulted in good prices. In 1926 prices were extremely low. ${ }^{264}$

California Gravenstein Apple Growers.-Despite the poor results attained by the Gravenstein Growers and Packers, the movement for joint action by growers and dealers gained new strength after the 1926 season had brought decidedly lower returns to the Gravenstein apple industry. As previously mentioned (page 86), in the fall of 1926 sixteen small committees of orchardists were appointed in the various communities for the purpose of working out ways of improving marketing conditions. Out of this group of committees grew a committee of five. This committee came to the conclusion that under prevailing conditions it was adrisable to try to unite the cooperative and private marketing agencies instead of trying to build one big cooperative organization for the Sebastopol region.

Starting from this premise the committee evolved a set-up which was somewhat different from those which had previously been developed. The plan involved the creation of a large growers' association with an attached clearing house which was to be controlled by the organized growers. The fundamental idea of this plan, it may be mentioned in passing, was taken from a plan then being proposed for the prune and apricot industries. ${ }^{265}$ The plan which the committee finally submitted may be summarized as follows:

1. It was proposed to organize at least 80 per cent of the producers of Gravenstein apples into a growers' organization under the name of

263 California Produce News 28(17):1-11. 1925. Also elipping from Santa Rosa Press Democrat. April 14, 1925.

264 Average prices a packed box were: $1924, \$ 1.15 ; 1925, \$ 1.96 ; 1926, \$ 0.39$. See: Rauchenstein, E. Factors affecting the price of Gravenstein apples at Sebastopol. Hilgardia 3:326. 1928.

26.5 The so-called "Parker plan" proposed by J. M. Parker, general manager of the California Prunc and Apricot Growers' Association. For a description of this plan see Sunsweet Standard 11(2):5-19. July, 1927. 
California Gravenstein Apple Growers. 'T'his organization, also referred to as Central, was to be formed without capital stock. 'The voting was to be done on a one-man-one-vote basis. Furthermore, it was provided that any grower of Gravenstein apples who would agree to comply with the marketing stipulations set forth in the plan could become a member.

2. There were to be two kinds of contracts, one between the grower and Central, and another between Central and the several marketing agencies called "units." Among other things, the contract between grower and Central provided that the grower should deliver all his Gravenstein apples to one of the affiliated marketing agencies. It further provided that the grower should notify Central not later than May 15 in 1927, and during the first twenty days of February in later years, of the unit through which he desired to market his crop. The contract between Central and marketing agencies, independent or cooperative, stipulated among other things that a clearing house should be established. It also provided that the units agree to handle no Gravenstein apples other than those produced, acquired, or controlled by grower members of Central except as specially mentioned in the agreement. Moreover, there were a number of similar features in both contracts which provided: (1) that the agreement with Central should be valid for fifteen years with the possibility of withdrawing annually within a certain period after the first two years had expired; $(2)$ that liquidated damages of 50 cents a packed box or each 45 pounds net weight should be paid in case of a violation or breach of contract; and (3) that the effectiveness of the agreement should depend upon the sign-up of a minimum of 847,000 boxes of Gravensteins, that is, 80 per cent of the estimated commercial pack during the fruit season of 1926 in Sonoma County.

3. It was proposed that the membership of Central was to be divided into so-called "membership units" each one consisting of those growers who had decided to deliver their crop to it. Each unit was to elect one director. In a special effort to safeguard grower control, it was provided that in the event the number of directors representing commercial membership units should exceed the number of directors representing cooperative membership units, the total voting power of the first group of directors was to be equal to the total voting power of the latter. Decisions were to be made by majority vote of the directors. As to the desired functions of Central, it was to announce minimum f.o.b. prices from time to time after having received the advice of the Clearing House Board, the administration of the clearing house, and the recommendation of clearing house members representing two-thirds of the 
tomnage. It was further to review all claims and adjustments originating in connection with the clearing house. It was to be entitled to direct unsold fruit to other markets or to cold storage or to order it to be turned into by-products. Moreover, it was to promote the interests of the apple industry in various ways and to be entitled to assess the fruit of its members for the purpose of covering its expenses.

4. It was suggested that the management of the Clearing House Board should consist of representatives of each unit and an equal number of growers appointed by the directors of Central. The clearing house was to have a secretary who should keep a daily schedule of shipments and sales and collect other useful information. Furthermore, no agency affiliated with the clearing house should be allowed to solicit business or to sell at prices which were below the minimum set by Central.

With this plan, which provided for a clearing house with regulatory powers, the committee thought it would be possible to overcome the conflict of interests which would inevitably develop. It believed that the plan would gain the support of practically all the Gravenstein apple growers and the assistance of the cooperative and independent marketing agencies because it permitted the growers to market through marketing agencies of their own choice, and permitted them to shift to others from time to time if they so desired with only the restriction that the agency selected be affiliated with Central and be a member of the clearing house. The committee also felt that the plan would be attractive to the growers because it placed control of the distribution of the crop in the producers' hands by giving Central important powers over the clearing house, and because it aimed to bring about a coordination of business on an industry basis.

The plan was adopted by the committee of sixteen representing the various fruit growing districts and was approved by the important existing marketing agencies. The California Gravenstein Apple Growers was therefore incorporated in January, 1927. The subsequent membership campaign was very successful. About 1,500 growers representing more than 95 per cent of the Gravenstein tonnage of Sonoma and Napa counties became members of Central. In addition, practically all the existing marketing agencies joined the clearing house. ${ }^{266}$ Four of these marketing agencies were cooperative associations, namely : The Sebastopol Apple Growers' Union; the Gravenstein Apple Grower's' Associa-

266 The names of the different units were: Garbro Fruit Company, Gareia and Maggini Co., Geyserville Growers, Gravenstein Apple Growers' Cooperative Association, Healdsburg Gravenstein Apple Growers, J. F. Miller \& Sons, Pacific Fruit Exchange, Pioneer Fruit Company, Geo. A. Ross \& Son, Sebastopol Apple Growers' Union, Seaton Fruit Co., and Sonoma Valley Apple Growers' Association. 
tion, which sold through the California Fruit Exchange; the Sonoma Valley Apple Growers' Association; and the Healdsburg Gravenstein Apple Growers. The last two associations sold through the Federated Fruit and Vegetable Growers, which at that time made strenuous efforts to gain a footing in the California Gravenstein industry.

During the shipping season of 1927 the organization functioned smoothly. The crop was but 60 per cent as large as in the previous year and prices were good- $\$ 1.66$ a box as compared with $\$ 0.39$ in 1926 . The real test came with the crop of 1928 , which was over twice as large as that of 1927. Opening prices proved to be too high, but there was opposition to lowering them. Representatives of neither the cooperative nor the private "units" were willing to propose lowering the price although some in both groups fully realized the true situation. A total of 1,932 cars was shipped by the various units of the clearing house as compared with 909 in the preceding season. Prices broke badly toward the latter part of the season. Growers were not prepared for such low prices. Accusations of underhanded practices were hurled at certain private shippers, and confidence in the organization fell to a point where the plan was finally given up before the season had entirely closed. Here, as in so many other cases, the clearing house was blamed for not controlling a surplus when, as a matter of fact, the plan of operation and set-up were not suitable for that purpose. No definite provision was made for allocation of permissible shipments in case all could not be marketed at the fixed asking prices, and no adequate machinery was provided for carrying out any such plan. All that was done was to name a minimum price. This was too high to move the crop at the rate it was being offered, consequently apples began to accumulate in the hands of desperate shippers. Then the usual thing happened-some one made concessions and sales.

Following the annual meeting of Central in January, 1929, a committee was appointed to work out recommendations for improvement of the plan. ${ }^{267}$ This committee made a number of recommendations including the following:

1. That the number of sales units in the clearing house be reduced by making it necessary that every membership unit have the equivalent of at least $7 \frac{1}{2}$ per cent of the previous season's total pack shipped by all units.

2. That provision be made for the employment of a general manager to be appointed by the Directors of Central.

3. That maturity requirements be more strictly enforced during the early part of the season.

267 Report of committee at special meeting of February 5, 1929. The members of this committee were: A. B. Swain, Chairman; Harvey C. Frost, A. M. Garcia, W. W. Monroe, E. C. Merritt, George Cassidy, and A. L. Siegle. 
4. That the membership of the clearing house consist of only one representative or sales agent of each membership unit.

5. That the different membership units shipping through a given sales unit shall not have more than one representative on the Board of Directors of Central.

6. That a monthly bulletin be published to improve the contact between the organization and its members, this to be supplemented by weekly circulars during the shipping season.

7. That consideration be given to the construction of large unit driers.

It is interesting to note that the committee stressed particularly the importance of the appointment of a general manager. Some of the leaders had urged the employment of a general manager from the beginning and were inclined to lay the failure to the lack of such a "strong man." This proposal had been rejected by the majority of the clearing-house members.

When the committee report was discussed at a special meeting held by Central in February, 1929, the idea of employing a general manager was approved. The proposal to reduce the number of units in the clearing house was, however, rejected, as were the proposals to change the voting system of Central and clearing house, since the growers were not willing to give up the special privilege accorded to them in the original plan, and since not enough sentiment existed for placing the voting power of the members of the Clearing House Board on a tonnage basis.

The movement for the improvement of the set-up and plan of operation of the California Gravenstein Apple Growers did not proceed further. The recommendations evidently required too many concessions and had come too late in the season to permit ironing out the differences.

It was therefore decided in March, 1929, to discontinue the clearing house. It was thought advisable, however, to maintain the California Gravenstein Apple Growers. The latter appointed a new committee for the purpose of studying further the possibilities of improving marketing conditions. This committee proposed to reorganize Central in such a way as to convert it into a cooperative marketing association - the one big cooperative for the Gravenstein apple industry which has been the ideal of some of the leaders. Nothing came of the proposals. 


\section{SUMMARY AND CONCLUSIONS}

Cooperative marketing in the California fresh-deciduous-fruit industry has been in process of development for sixty-odd years. During this period it has gradually gained in importance. Today, approximately 8,000 growers are organized in some 90 local cooperative associations which handle about 30 per cent of the fresh deciduous-tree fruits and about 11 per cent of the fresh grapes shipped from California, as well as some portion of such commodities sold in the state itself. Most of these organizations are federated into a general sales organization, the California Fruit Exchange.

The earliest instances of collective action were efforts to improve the transportation of fruit. The first of these occurred in 1869 when the completion of the overland railroad opened prospects of new markets in the East. This organization, the California Fruit Growers' and Dealers' Association, was a combination of growers and dealers, and had as its major purpose the reduction of freight rates and the development of eastern outlets. It seems to have done nothing but negotiate with the railroads. (See pages 5 to 7 .)

Examples of local collective action followed shortly thereafter and consisted of informal efforts of local groups of farmers to reduce the costs of shipping fruit to California markets. (See pages 7 and 8.)

The first plan for the establishment of a state-wide grower-owned and grower-controlled cooperative marketing system for fresh deciduous fruits was drafted in 1885. This plan led to the creation of the California Fruit Union. It provided for the organization of a central cooperative association with stock owned by individual fruit growers. Such local associations as developed were to load the fruit and the Union was to ship and sell it.

After its first year the Union became a grower-dealer organization. It was organized during the business depression of 1885 just after several years of marked increases in fruit shipments. Having lost its grower character and having failed to obtain the expected market control, it passed out of existence during the business depression of 1894 , after further marked increases in shipments had led to low prices. (See pages 13 to 29 .)

When the cooperative movement got under way among citrus-fruit growers in southern California during the middle nineties, attention was attracted to the advantages of a federated type of organization, the "exchange system." The California Fruit Exchange, a dried-fruit organ- 
ization, developed in the Santa Clara Valley, and sought to spread its influence over the state. After the California Fruit Union passed out of existence, it sought to get the fresh-fruit growers in to form local associations and affiliate with it. Nothing came of this movement (see pages 31 to 33 ).

The exchange system attracted further attention when the Southern California Deciduous Fruit Exchange was organized for the sale of dried fruits (page 39). Moreover, both the manager of this organization and of the Southern California Fruit Exchange urged the development of a federated type of organization for the fresh-deciduous-fruit growers.

It was not until 1901, when the California Fresh Fruit Exchange was formed (now the California Fruit Exchange), that another state-wide organization for the sale of fresh deciduous fruits developed. Although it was first proposed to make this a direct membership type of association patterned after the then successful California Raisin Growers' Association and the California Cured Fruit Association, the advocates of the federated type won.

After many difficulties, particularly in the early years, the Exchange has become a very important factor in marketing California deciduous fruit. In 1931 it marketed 22.7 per cent of the fresh deciduous-tree fruits and 9.7 per cent of the fresh grapes shipped out of the state. Its superior fruit is sold under the Blue Anchor brand, which has gained a high reputation in the United States and abroad. The Exchange furnishes most of the supplies needed by its affiliated local associations. Furthermore, it performs valuable services in matters of standardization, advertising, transportation, insurance, and public relations. It coordinates the activities of the large majority of the existing local cooperative associations for fresh deciduous fruits and has spread its grower connections over the entire state and into Arizona. Last but not least, in collaboration with the California Fruit Growers' Exchange (formerly the Southern California Fruit Exchange), the organization has built up an effective sales system and has made good progress in the development of an export business.

So far as local and regional developments are concerned, there is relatively little aside from the local units affiliated with the California Fruit Exchange. There are perhaps a dozen independent cooperatives today marketing fresh deciduous-tree fruit or grapes and, in addition, one regional organization, the Sebastopol Apple Growers' Union. The cooperative movement has suffered in the Sebastopol area because of a split in the membership of the Sebastopol Apple Growers' Union which 
occurred in 1924. Little progress has been made so far in the Watsonville region.

The basic reason for the urge to form cooperative associations throughout the period of sixty-odd years has been low prices to growers. The reasons given in explanation of low prices have been substantially similar throughout the period with some variations in emphasis. The principal reasons were: (1) High freight and refrigeration charges. Practically every organization discussed has at some time or other participated in attempts to reduce these charges or to improve the services without increasing charges. At one time there was even a strenuous effort to form an organization of growers to develop its own refrigerator car line (pages 39 to 40). (2) High charges by California packers and shippers and by dealers in the East. (3) Dishonest or questionable practices on the part of shippers or on the part of the trade in eastern markets. (4) Lack of aggressiveness on the part of private shippers in developing new markets and correcting evils in transportation or in the eastern markets. Much was said of wide dealers' margins in the East.

(5) Disorganization of markets. Most commonly the complaint has been that individual markets are alternately oversupplied or undersupplied. Sometimes, in addition, the total supply to all markets was considered too great.

The basic reason for low prices seems to have been the pressure of supplies on demand. Consumers' habits change showly. Plantings were increasing rapidly, particularly after every reasonably prosperous or promising period. Thus from 1871 to the bumper crop year of 1876 shipments increased from 916 tons to 2,101 tons, or 129 per cent. Again, from 1876 to 1881 they increased from 2,101 tons to 3,614 tons, or 72 per cent. And to take a more recent period, from 1920 to 1925 shipments of apricots, cherries, peaches, pears, and plums increased from 10,709 cars to 15,201, an increase of about 42 per cent.

As a result, even a year of normal yield was at most times a year when each local newspaper editor or Chamber of Commerce enthusiast could boast "the biggest shipment of fruit in the history of our fair city." Every year of good crops was a year of surplus, a year when there was much complaint of "red ink." 268

Throughout the history of cooperative marketing of fresh deciduous fruits the same names reappear again and again in a series of movements-the cooperatively minded. Time and again is voiced the complaint that many producers will not cooperate, or that they prefer to

268 That is, when returns in the East were so low that growers had to raise additional funds to pay freight and refrigeration. 
listen to and deal with private firms rather than the cooperative leaders and their organizations. The notion has been widespread, even among many of the noncooperators, that substantial grower control on an industry basis is not only desirable but even necessary. Yet, as one speaker put it, "you can get one-third of the growers together in an organization; these can get another third to join; but no power outside the Almighty can draw the other one-third in."269

Because the growth of cooperative activities was not sufficiently rapid to give the degree of control desired by those who emphasized disorderly marketing, there have been repeated attempts to combine grower and dealer interests so as to include in the organization practically all of the fruit. 'The California Fruit Growers' and Dealers' Association of 1869 (Page 5), the California Fruit Union of 1885-1894 (page 13), and the California Fruit Growers' and Shippers' Association of 1894 to 1901 (page 29), were the forerunners of a whole group of such organizations, attempted or realized during the past decade and a half. Some of these involved the establishment of clearing houses which merely supplied information; sometimes the clearing houses were also to have regulatory powers; and in a few cases the organizations were really joint selling organizations (pages 104 to 116 ).

General-purpose farm organizations have played an important part in the cooperative marketing movement. 'The farmers' clubs of the early seventies, the grange during the late seventies and early eighties, the Farmers' Alliance in the early nineties, the Farmers' Educational and Cooperative Union in the first decade of the present century, and the farm bureau since about 1920 have all favored, encouraged, and even promoted cooperative marketing in various lines.

The sum total of discussion of cooperation in the meetings of these organizations, and during the various cooperative movements, has brought up and examined almost every sort of cooperative notion. This discussion has been crystallized into a fairly clear understanding of cooperative practices and problems on the part of a considerable group of growers in practically every locality. This understanding promises continued progress in the development of the marketing system for fresh deciduous fruits.

269 A Mr. Gordon at the Thirticth Fruit Growers' Convention, December, 1904. California State Commissioner of Horticulture, First Bien. Rpt. 1903-04:311-12. 


\section{ACKNOWLEDGMENTS}

The authors desire to express their appreciation for the assistance rendered by the numerous persons who supplied information or who made available certain records from which data were obtained.

The authors are particularly indebted to the following persons: Mr. E. C. Merritt, Manager of the Sebastopol Apple Growers' Union; Mr. E. W. Stillwell, then manager of the clearing house of the Grape Control Board; Mr. J. L. Nagle, Manager, and Mr. Fred Read, in charge of the Standardization Department, of the California Fruit Exchange; and to Professor E. A. Stokdyk and Dr. S. W. Shear of the Giannini Foundation of Agricultural Economics of the University of California. All of these men not only supplied or made available important data but also read the manuscript and offered suggestions for its improvement. 
